Universidad Nacional de La Plata

Facultad de Periodismo y Comunicación

Maestría en Planificación y Gestión de los Procesos Comunicacionales

\title{
Política Agraria y Comunicación
}

El INTA y su propuesta de intervención rural

Directora: Nancy Díaz Larrañaga

Tesista: Juan Francisco Vinuesa 
Marzo de 2012

\author{
Agradecimientos, \\ a todos los que acompañaron, \\ y aportaron a este proceso; \\ a mi Lelita, \\ por enseñarme el amor a lo público.
}




\title{
Política Agraria y Comunicación
}

\author{
El INTA y su propuesta de intervención rural
}

\section{Introducción}

La maestría que nos convoca, PLANGESCO, promueve formar profesionales capacitados para investigar, planificar y gestionar la comunicación en diferentes prácticas sociales, en instituciones públicas y privadas, tomando en cuenta los procesos comunicacionales propios de las relaciones interpersonales, grupales, intra e interinstitucionales y con la comunidad en general, desarrollando investigaciones que contribuyan a la producción de saber en este campo.

Esta tesis ahonda e investiga la temática de la comunicación rural, y los modos de intervención rural de la política agraria, desde mediados de los años '50 hasta la actualidad. Entiendo inevitable realizar un análisis de las modalidades de la comunicación rural, y los enfoques de la extensión agraria, dando cuenta de las políticas macro que las orientan y su contexto socio-político de producción.

Relacionar y entender a la extensión rural como instancia donde emerge la dimensión comunicacional, es dar cuenta de que toda intervención se construye desde una relación, mediada o no, entre actores sociales. Y este proceso de interacción guarda una propuesta de comunicación implícita, una relación cultural, en tanto produce y valida sentido social.

La presente tesis busca entrar en diálogo y tensión con las concepciones y proyectos institucionalizados de la comunicación rural y extensión agraria que se vienen desarrollando en Latinoamérica desde el desembarco del desarrollismo (los años '50) hasta la actualidad, haciendo énfasis en cómo se presentan éstas nociones y estrategias en el Instituto Nacional de Tecnología Agropecuaria (INTA) de Argentina.

Así también este trabajo guarda la intención de pensar el abordaje social de una unidad del INTA, desde nuevas concepciones de lo comunicacional y la intervención en la política 
agraria; para así poder habilitar nuevos destinatarios acreedores de proyectos de origen público, no considerados en su integralidad hasta la actualidad. Para desarrollar lo anteriormente descripto se presentan tres componentes:

En el componente I propongo: i) trazar un recorrido, por las opciones y conceptualizaciones teóricas presentes en las prácticas y estudios de la comunicación rural en Latinoamérica, desde sus orígenes desarrollistas y en relación con los modelos de intervención agraria, referenciando el análisis desde su construcción en el INTA (Instituto Nacional de Tecnología Agropecuaria); ii) describir los distintos enfoques, las renovaciones críticas, de la comunicación rural dando cuenta del contexto socio-histórico en donde se desarrollaron. iii) investigar la estructuración que el neoliberalismo imprimió sobre los institutos de ciencia y tecnología, a partir de mediados de los '70; y en el modo de producción agropecuaria argentina. iv) descifrar el enfoque instituido de la comunicación y la extensión en el INTA a lo largo de su historia, y en la actualidad.

En el Componente II nos detendremos en la etapa neoliberal, profundizando el análisis, desarrollando los distintos instrumentos disponibles y conceptualizaciones que ofrece dicho paradigma para la comunicación y la intervención social; entre ellos "participación”, "pobreza”, “intervención”, "planificación”. Dar cuenta de la aplicación de estos conceptos y dinámicas en el INTA, nos acercará a entender el proceso que experimentó dicho instituto en estos últimos años. Al concluir el componente se desarrollan algunas líneas de reflexión para poder pensar la comunicación social y el trabajo comunitario desde otros enfoques y aportes críticos.

Después de todo el análisis socio-histórico e ideológico de las estrategias de comunicación rural y extensión agraria del INTA a lo largo de su historia; después de haber pensado otras líneas posibles de una comunicación social en territorio, es oportuno armar un Componente III donde entren en tensión lo instituido y lo que puede emerger. A partir de una contextualización de una unidad del INTA (Unidad Formosa), se propone poder pensar los alcances de nuevas estrategias de comunicación y extensión rural, para nuevos destinatarios ya vigentes en el territorio, que emergen desde estas miradas críticas. Desarrollo entonces un primer acercamiento a aquellos actores colectivos que quedan relegados, por fuera de las políticas y proyectos del INTA, para así repensar la posibilidad de habilitar un espacio de 
trabajo social dentro de esa Unidad para con estas organizaciones colectivas, logrando políticas públicas ampliadas que involucren a los actores organizados del territorio. Dar cuenta de este olvido que el INTA lleva desde sus orígenes, es ratificar la vocación productivista de las políticas agrarias y sus instrumentos que se vienen desarrollando. La idea es replantear principalmente los destinatarios segmentados que el INTA estructuró a lo largo de su historia, para irrumpir y hacer ingresar desde una otra mirada comunicacional del territorio, hacer emerger otros sujetos posibles de articulación con la política pública agraria. A modo de cierre de este apartado presenta una serie de líneas generales de acción, trayectos a desarrollar.

\section{¿Por qué comunicación rural?}

Pues trabajo desde una beca de investigación postgradual del Instituto Nacional de Tecnología Agropecuaria (INTA), en coordinación con el Grupo de Comunicación y Capacitación del Área de Extensión Rural, de la Estación Experimental Agropecuaria, ubicada en el Colorado, provincia de Formosa. Dicha unidad trabaja en las zonas rurales, periurbanas de la provincia de Formosa y gran parte de la provincia del Chaco. Las becas del INTA son entregadas en un $97 \%$ a jóvenes profesionales de las ciencias agrarias, y el resto a profesionales de las ciencias humanas y sociales. Estas últimas son referidas territorialmente a las zonas postergadas y marginadas del país. La presente beca tiene como título "comunicación para el desarrollo rural", y soy el primer cientista social que ingresa a trabajar al INTA de Formosa. La propuesta laboral se divide en dos períodos, uno de trabajo territorial en el área de extensión en las provincias mencionadas, de dos años de duración; y el segundo momento es de formación postgradual, nivel maestría, en el cual me encuentro actualmente. Descifrar y analizar las experiencias y estudios de la comunicación rural es contextualizar el lugar desde donde hablo, es identificar y diseñar líneas posibles de intervención social desde la comunicación.

\section{Metodología}


El análisis que presenta esta tesis se desarrolla en el enfoque cualitativo de la investigación en ciencias sociales; en los dos primeros componentes (I, II) se trabaja desde el análisis ideológico del discurso, y en el componente III se utilizan herramientas etnográficas y comunicacionales para iniciar un diálogo con distintos actores comunitarios. Estas dos modalidades completan la metodología utilizada en este trabajo para dar cuenta de los objetivos planteados.

El análisis ideológico del discurso, refiere a la puesta en relación de los discursos con el contexto socio-histórico, descifrando la ideología que atraviesa y habla desde estos discursos. Rastrea lo instituido y cristalizado, (lo que Castoriadis1 dio en llamar el "imaginario social efectivo") dentro del entramado discursivo de un actor organización o política.

"Por eso Castoriadis dice que lo instituido, en el dominio histórico-social, funciona con el principio que el epistemólogo chileno Francisco Varela llama cerco, de clausura. Cada mundo es clausurado o cerrado en sí, en el sentido de que hay una coherencia de significaciones y procesos que se mueven dentro de un cerco." (Bonanno, 20082)

Como nos orienta Van Dijk el análisis del discurso "es una postura crítica" , que permite reconocer la ideología de los discursos, mediante un "análisis exhaustivo"; que implica a la vez un estudio del discurso sociopolítico (Van Dijk, 1996).

“ El propósito del análisis del discurso ideológico no es simplemente "descubrir" las ideologías subyacentes, sino articular sistemáticamente las estructuras del discurso con las estructuras de las ideologías. No se requiere ser analista del discurso para concluir que un relato noticioso, el fragmento de un texto o una conversación determinada es "conservadora", "sexista" o "ecologista". Nuestro conocimiento ingenuo del lenguaje, el discurso, la sociedad y las ideologías nos conducen a menudo hacer tales inferencias con relativa certeza. Sin embargo, un estudio más explícito y analítico del discurso exige una formulación más clara de tales instituciones, e intenta especificar que expresiones o significados del discurso dan lugar a qué clase de

1 Castoriadis, Cornelius. "La institución imaginaria de la sociedad”. Tusquets Editores, México 1975

2 Bonanno, Osvaldo. "Castoriadis", en Revista El Emergente Psicosocial Nº1, 2008. 
inferencias u otros proceso mentales" (Van Dijk, 1996)3

Podríamos concluir que el análisis cultural da cuenta de este carácter histórico y social del discurso, pero no se agota en esta dependencia discurso-contexto, sino que necesita de interpretación.

El proceso de interpretación se construye sobre la base del análisis histórico y discursivo; retoma los hallazgos aportados por estos análisis y los emplea como elementos de una interpretación creativa y constructiva. (...) Por muy rigurosos y sistemáticos que sean los métodos del análisis formal o discursivo, estos no pueden evitar la necesidad de una construcción del significado, es decir, de una explicación interpretativa de lo que es representado o dicho. (Thomphson, 1991)4

En segunda instancia, en el componente III se da cuenta de un primer acercamiento al territorio y sus actores colectivos. Es aquí donde el enfoque cualitativo valora al diálogo, la relación discursiva entre sujetos, como producción de conocimientos. Para este primer abordaje se utilizaron las herramientas etnográficas de la entrevista semiestructurada, la relatoría y cuaderno de campo, como los talleres participativos, para así recuperar las voces de los involucrados en organizaciones comunitarias.

conjunto de sus experiencias, sus preplejidades, sus memorias, su imaginación y sus perspectivas respecto del prorvenir. (Villalba, 2008)5

Los talleres participativos fueron puestos en práctica en tanto fortalecen una instancia de producción del conocimiento de modo más democrático y plural, ya que la suma e interacciones de las reflexiones personales puestas en juego sobre una temática o problemática, logran un nuevo saber compartido.

Podríamos así, encuadrar esta segunda instancia de la tesis, en tanto diagnóstico

3 Van Dijk, Teun A “Análisis del Discurso Ideológico” Versión 6 UAM México. 1996. pp. 15-43.

4 Thompson, John (1991) "La comunicación masiva y la cultura moderna. Contribución a una teoría crítica de la ideología”, en Revista Versión, №1, universidad Autónoma Metropolitana , México. 1991.

5 Claudia M Salazar Villalba, El sujeto no es objeto de investigación. Trabajo presentado en el cuarto encuentro de investigadores en Psicología del Mercosur, 2008. 
comunicacional como herramienta de producción de conocimientos, (y no como momento estanco y limitado de una planificación). La Unidad de Prácticas y Producción de Conocimiento, de la Facultad de Periodismo y Comunicación Social, de la Universidad Nacional de La Plata entiende que el diagnóstico socio-comunicacional es una herramienta a través de la cual,

\begin{abstract}
"profundizamos nuestro conocimiento, nos relacionamos, nos conocemos con otra gente. Porque diagnosticar también es conocerse, enredarse, entreaprenderse con los otros, con sus sentidos sobre la realidad en la que viven y con la que se relacionan cotidianamente."
\end{abstract}

En términos del profesor Daniel Prieto Castillo el diagnóstico es "una lectura esencial de determinada situación social, una lectura de sus conexiones esenciales, desde una perspectiva histórica”. (Prieto Castillo7)

\footnotetext{
"Esta manera de investigar, produce resultados distintos a los enunciados de verdad propios de los enfoques metodológicos experimentales y cuantitativos. No se descubren realidades objetivas, sino que se abren horizontes posibles de sentido para nuestras sociedades que poseen la potencia de configurar prácticas." (Villalba, 2008)8
}

Se eligieron para desarrollar en esta tesis algunas experiencias sociales por sobre otras, ya que las expuestas guardan y son representativas de la homogeneidad y heterogeneidad de los actores colectivos de la zona rural de Formosa. Son entre sí distintas, pero guardan cuestiones transversales que nos permitirán orientar líneas de acción. Esto se llevará a cabo en el Componente III de este trabajo.

6 Unidad de Prácticas y Producción de Conocimiento. Sembrando mi tierra de futuro. Ediciones de Periodismo y Comunicación. 2011.

7 PRIETO CASTILLO, Daniel; Diagnóstico de la comunicación, CIESPAL, Quito, 1990, pág. 54

8 Claudia M Salazar Villalba, El sujeto no es objeto de investigación. Trabajo presentado en el cuarto encuentro de investigadores en Psicología del Mercosur, 2008. 


\section{Componente I.}

Enfoques y paradigmas de extensión y comunicación rural. Su estructuración desde el INTA.

\section{Extensión o Comunicación, retomando el debate, desarmando las prácticas.}

\section{En el principio se partió del desarrollo}

En su discurso de renovación y toma de posesión de la presidencia de Estados Unidos, Harry Spencer Truman pronunciaba en enero de 1949, su Discurso de los Cuatro Puntos. En el cuarto punto destacaba que: "tenemos que iniciar un programa nuevo y audaz para lograr que los beneficios de nuestros avances científicos y el progreso industrial disponible, para la mejora y el crecimiento de las regiones subdesarrolladas" (Truman, 1949). De esta manera logra ordenar, estructurar y dividir al mundo capitalista entre países avanzados, y países con atraso, inmadurez y pobreza, siendo el "desarrollo" el único camino posible para que estos últimos puedan alcanzar el bienestar de los primeros. Se institucionaliza así el "desarrollo" como el antídoto para lograr la modernización basada en el aumento productivo. Asociando marginalidad con primitivo, condiciones de miseria con amenaza, sufrimiento con subdesarrollo, progreso con saberes científico-técnicos, paz con avance tecnológico, libertad con aumento de la producción, y desarrollo con inversión extranjera, Truman enuncia que la clave para la paz y la prosperidad es producir más. "Y la clave para producir más es una aplicación mayor y más vigorosa del conocimiento técnico y científico moderno.” (Truman, 1949)

Estos postulados están alineados a la Doctrina Truman, que buscaba la manera de aliar voluntades y naciones para frenar el avance socialista en el mundo; el "desarrollo" entonces era el proyecto convocante para reducir y erradicar todas las aspiraciones de los países pobres 
hacia la opción comunista. La fuga de países al régimen soviético, no era más que una real amenaza al modo de funcionamiento del capitalismo. La Alianza para el Progreso, en consonancia con los postulados de Truman, y bajo la supervisión de Kennedy, fue el intento más estructural de la política norteamericana para con los países de Latinoamérica.

Uno de los documentos verticales, considerado así por distintos investigadores, que reunió los conceptos y las directrices para la planificación de políticas del desarrollo fue el informe que elaboraron diferentes expertos para las Naciones Unidas, en 1951, bajo el título de Medidas para el desarrollo económico de los países subdesarrollados. En él se dictamina:

\begin{abstract}
Hay un sentido en el que el progreso económico acelerado es imposible sin ajustes dolorosos. Las filosofías ancestrales deben ser erradicadas; las viejas instituciones sociales tienen que desintegrarse; los lazos de casta, credo y raza deben romperse; y grandes masas de personas incapaces de seguir el ritmo del progreso deberán ver frustradas sus expectativas de una vida cómoda. Muy pocas comunidades están dispuestas a pagar el precio del progreso económico. (United Nations, 1951 en Escobar, 1996)
\end{abstract}

Esta cita nos permite ver uno de los tantos supuestos despectivos hacia las "otras" culturas no encaminadas en el consumo masivo, son las tramas arcaicas de un mundo que se autocondena al "subdesarrollado". La desacreditación a toda práctica que no esté en sintonía con lo "moderno", es pensada como amenazante y urgente de cambiar para el bienestar mundial, y este proceso de estigmatización es una constante en los trabajos teóricos y metodológicos de las producciones académicas de la época.

La teoría del desarrollo nace desde una estrecha relación con las teorías del crecimiento económico y la teoría de la modernización, pudiendo afirmar que todas comparten un núcleo duro, al punto de poder pensarlas como una sola vertiente intelectual. En este núcleo duro se encuentran postulados el progreso positivista, la evolución de las sociedades en etapas, los pueblos inmaduros necesitados de guía y cuidado, de alguien que les dicte el camino a recorrer para lograr la vida adulta (ideas referidas en Comte, y Spencer). En cuanto a otra arista relacionante de estos postulados, podemos nombrar a las ciencias sociales, tema que nos

9 Escobar, Arturo. La invención del Tercer Mundo construcción y deconstrucción del desarrollo. Editorial Norma.1996. Pág. 21. 
convoca, y su incurrencia en el análisis estructural funcionalista de la sociedad, la sociedad entendida como sistema, como organismo (Paul, Preston, 1999) ${ }^{10}$.

Entre estas producciones teóricas, cabe destacar la elaborada por el economista norteamericano Walter Whitman Rostow, en su obra "Las etapas del crecimiento económico"; en la que detalla con suma precisión los estadios de madurez del paso de las sociedades del "bajo desarrollo" hacia las sociedades de "alto desarrollo", describe cinco etapas para pasar de una sociedad tradicional hacia un último estadio de madurez, que es la etapa del consumo en masa. Las cinco instancias son: 1) sociedad tradicional 2) etapa de transición 3) el despegue económico 4) el camino de la madurez 5) el consumo a gran escala. ${ }^{11}$

Hablar de la historia de la comunicación para el desarrollo rural es entonces referir a las Teorías del Desarrollo, de la Modernización y del Crecimiento Económico, pues para llevar adelante la transformación del mundo premoderno era necesario recurrir a mecanismos y técnicas de persuasión y difusión, que mostraran posibilidades de modificar las conductas de quienes se encontraban en ese atraso que describe el informe de Naciones Unidas anteriormente citado. La comunicación en su versión instrumental y a la medida del paradigma funcional positivista del "desarrollo", desplegó su quehacer territorial y su reflexión teórica en tanto herramienta para amplificar las "buenas" prácticas de la "nueva" vida rural. Armand y Michele Mattelart, en esta movilización para la modernización entiende a la comunicación y sus dispositivos como el "agente de la modernización por excelencia, irradiando y desmultiplicando las actitudes modernas de la movilidad"12. Es aquí cuando el corpus de estudios y experiencias de la comunicación rural, nacen y son guiados por el argumento de que es necesaria una comunicación persuasiva al servicio de la adopción de métodos y formas de producción que logren un aumento de las rentas per capita.

Con el advenimiento de estos paradigmas, el mundo rural latinoamericano y sus prácticas agrícolas sufrieron un proceso de intervención planificada por parte del Estado, en el amplio espectro de su territorio, a partir de la década de 1950. Como antes mencionamos, fue la Alianza para el Progreso, el proyecto que terminó de cristalizar las recetas para cimentar en

10 Preston, P.W. Una introducción a la teoría del desarrollo. Ed. Siglo XXI. México 1999.

11 Rostow, Walter Whitman. Las etapas del crecimiento económico. Editorial Fondo de Cultura Económica. 1961. México.

12 Mattelart, Armand y Michele. Historia de las teorías de la comunicación. Ed. Paidós. 1997. México. 
Latinoamérica un modelo de acumulación a base de asegurar países productores de materias primas, incrementando así el dominio y dependencia para con las industrias del norte. En esta lógica, gran parte de los préstamos y subsidios se destinaron a producir la tecnificación del medio rural latinoamericano. Es en este proceso histórico, que ubicamos al momento de génesis de la comunicación rural (o para el desarrollo rural), como proyecto y como concepto, adoptado y adaptado en este lado del mundo.

En el texto La Bocina que Parla, Cimadevilla, Carniglia y Cantú proponen dar cuenta de la aparición de los distintos estudios que aportaron y sintetizaron las experiencias y enfoques de la comunicación en ámbitos rurales. Entendiendo a los estudios de comunicación rural como una joven disciplina, los tres autores rescatan los antecedentes mediatos de la misma en la literatura y la sociología rural; y reconocen su impronta originaria en tanto instrumental.

Asumiendo la promoción incansable de la tecnificación de las prácticas tradicionales rurales, la comunicación se planifica como herramienta indispensable de los servicios de extensión. Dichos servicios surgen también como modalidad en este período ${ }^{13}$, y junto a la comunicación tienen la "imperiosa" tarea de transformar el mundo rural.

La tecnificación del mundo rural se basó a grandes rasgos en la industrialización de la agricultura; surge así la llamada "revolución verde", donde se promovió el uso de agroquímicos y fertilizantes, la maquinarización de muchas labores rurales, las técnicas de monocultivo intensivo; todo esto con el fin de lograr altos rindes con bajos costos. Varios caminos rurales fueron mejorados y abiertos para lograr ingresar las materias primas en el circuito de producción industrial mundial.

La "extensión", la "transferencia tecnológica", la "difusión de innovaciones", eran enfoques de una misma propuesta comunicacional, que orientaron las estrategias persuasivas de intervención para la modificación y adopción de conductas. Muchos investigadores del campo comunicacional y social reconocen a la obra de Everett Roggers Difusión de Innovaciones (1962) (“Diffusion of Innovations”), como el exponente teórico más importante e influyente de esta primera etapa de la comunicación rural latinoamericana. Entendiendo a la sociedad como un sistema, Rogers define al desarrollo como "un tipo de cambio social en el

13 Fueron parte de las estrategias del New Deal, de Roosevelt en Estados Unidos. Y de ahí se promovieron años más tarde en Latinoamérica. 
que se introducen nuevas ideas en un sistema a fin de producir elevaciones en los ingresos per capita y mejores niveles de vida, por medio de métodos de producción más modernos y mejoras en la organización social." 14

En su texto, Rogers logra tipificar, y hasta llega a medir en porcentual, los distintos receptores de la divulgación técnica, están: a) los innovadores o generadores, que son los primeros en utilizar la innovación dentro del sistema social. (2,5\%); b) los primeros adoptantes, son reconocidos como líderes capaces de influenciar la conducta de otros en el negocio. $(13,5 \%)$; c) la primera mayoría, que necesitan tener referencia de experiencias exitosas antes de adoptar la innovación. (34\%); d) la mayoría tardía, son los escépticos, que asumen un aire de desconfianza y cautela ante las innovaciones y se sienten incómodos con la tecnología y les resulta indispensable la presión de sus congéneres para motivar la adopción) (34\%), e) y los rezagados, que son los últimos en adoptar la innovación,o simplemente la rechazan, descriptos como tradicionales, su única referencia es el pasado y toman sus resoluciones con el criterio de lo que ha realizado la generación anterior, $(16 \%){ }^{15}$

Cimadevilla, Carniglia y Cantú, en el texto anteriormente citado, describen y dan cuenta de algunas condiciones que sustentan la estructura del modelo difusionista de la comunicación rural de esos años:

“a) el reconocimiento de un estado de realidad social o productiva no deseable;

b) un plano de decisión política que opta por la intervención externa mediante una institución específica;

c) la existencia de un conocimiento superador de aquel que rige la práctica productiva o social de un determinado lugar;

d) la existencia de una infraestructura generadora de ese conocimiento;

e) la existencia (o necesidad) de una infraestructura transferidora;

f) que la transferencia sea posible y deseable; $y$

g)la existencia de una población cuya conducta puede modificarse a partir de una intervención." 16

14 Rogers, Everett La comunicación de Innovaciones. (Trad. Ricardo Vinos) México. 1974. Pág 347.

15 Rogers, Everett en García Urrea, Difusión de Innovaciones, Material Didáctico. Edit. Scribd.com . Enero 2008.

16 Cimadevilla, Carniglia, Cantú. La bocina que parla, Antecedentes y Perspectivas de los Estudios de Comunicación Rural. Ed. Universidad Nacional de Río Cuarto. 
Intentando un profundo análisis y recorrido de las teorías de comunicación, Armand Michèle Mattelart, desanda los postulados de Rogers, y argumenta que la estrategia difusionista se confundía en la práctica con la de marketing de productos. ${ }^{17} 18$

Es en estos años, impulsado por una fuerte recomendación del economista Raúl Prebish $^{19}$, secretario de la Comisión Económica para América Latina (CEPAL) de las Naciones Unidas, que observaba con preocupación la caída de las exportaciones agropecuarias de argentina, se crea, bajo el gobierno inconstitucional de facto de Aramburu, el Instituto Nacional de Tecnología Agropecuaria (INTA). En el estudio que inspiró el armado de dicho Instituto, el economista argumenta:

"La revolución tecnológica que urge llevar a cabo en el campo argentino no podrá cumplirse sin dedicar esfuerzo considerable y persistente a la investigación agropecuaria, a las tareas de extensión y enseñanza, tanto para formar investigadores y divulgadores, como para proporcionar al agro hombres capaces de llevar a la práctica la nueva tecnología." ${ }^{20}$

El INTA fue el encargado de coordinar e implementar el paradigma de modernización económica agraria, a través de la tecnificación del medio rural en Argentina. Por decreto y en diciembre de 1956, el INTA nacía con el fin de "impulsar y vigorizar el desarrollo de la investigación y extensión agropecuarias y acelerar con los beneficios de estas funciones fundamentales: la tecnificación y el mejoramiento de la empresa agraria y de la vida rural"21

Podemos entonces sostener que en el proyecto de modernización de América latina, de los años 50` y $60^{`}$, se encuentran los primeros pasos de la comunicación rural, en tanto posible disciplina, en tanto programación institucional, en tanto estudios y manuales de procedimientos. Raúl Fuentes Navarro en su intento de dar cuenta de la investigación latinoamericana en comunicación, recurre a los aportes de Luis Ramiro Beltrán para describir las orientaciones conceptuales y metodológicas que orientaron estos estudios. Refiriendo a la

17 Mattelart, Armand y Michele. Historia de las teorías de la comunicación. Ed. Paidós. 1997. Pág 108.

18 Lo que se dio en estos servicios de extensión y comunicación rural fue también una adaptación de la estrategia del Flujo de Dos pasos de Lazarfeld y Kats. El extensionista debía formar un líder o al referente comunitario en los valores y saberes del nuevo desarrollo, y éste buscaría replicarlo en su comunidad.

19 Economista argentino fundador junto con Singer del estructuralismo latinoamericano.

20 Prebisch, Raúl. Informe de la Comisión Económica para América Latina. (1959)

21 Historia del INTA. Ediciones INTA. 2006. 
etapa que estamos describiendo, ambos autores coinciden en señalar una orientación norteamericana,

\begin{abstract}
"positivista, empirista, sistemática y funcionalista, especialmente en los trabajos de difusión de innovaciones agrícolas, estructura y funciones de los medios y comunicación educativa, es decir, la televisión, radio y audiovisuales grupales." 22
\end{abstract}

Hasta incluso algunos autores referentes de este período, de las academias de los países dominantes, llegaron a pensar que la comunicación traería de por sí el "desarrollo", que era inductora eficaz del cambio. (Daniel Lerner, WilburSchramm) ${ }^{23}$

\title{
Críticas a la divulgación o, el repensar la comunicación desde
} abajo

Al paso de unos años de implementación de los planes y servicios de la Alianza para el Progreso, voces críticas comenzaron a emerger de distintos ambientes (académico, militante, movimientos sociales, entre otros). El "desarrollo" no sólo no había llegado, sino que sus políticas incrementaban las desigualdades en varios de los países, y profundizaban la disparidad entre las naciones "premodernas” y los países dominantes. La distancia madurativa se agrandó, se polarizó, el niño fue más pequeño, y el grande creció más. La comunicación, (en sus instrumentos y medios masivos) que debía acortar estos plazos de las etapas de modernización, fue puesta en discusión.

"La comunicación-agente del cambio social se ha ofrecido allí como salida

22 Fuentes Navarro, Raúl. La investigación de la comunicación en Ámerica Latina: condiciones y perspectivas para el siglo XXI. Díalogos de la Comunicación N 56, Felafacs, Lima, 1999.

Beltrán, Luis Ramiro, Comunicattion research in Latin America: ¿the blind folded inquiry?, International Scientific Conference on Mass Comunicattion and Social Consciousness in a Changing World, IAMCR, Leipzig,. 1974. p.23

23 Lerner, Daniel and Schramm, Wilbur, Eds. Communication and change in the developing countries. Honolulu, Hawaii, East-West Center Press, University of Hawaii. 1967.

Lerner, Daniel . The passing of traditional society. Glencoe, Illinois, Free Press. 1958

1963.

Schramm, Wilbur . Communication development and the development process. In: Pye, Lucien W., ed.

Communications and political development. Princeton, N.J., Princeton University Press. 
para el subdesarrollo, aportando su contribución a la racionalización de los comportamientos en el ámbito de la planificación familiar, de los métodos agrícolas y de la alfabetización. Hasta el día en que la concepción lineal del desarrollo/progreso, inspirada en la historia industrial de Occidente, entró en crisis abriendo un nuevo campo de debates acerca de las condiciones de una democracia internacional en los intercambios culturales y señalando la aparición de otros actores, de otras culturas, de otras historias, de otras formas de ver, distintos de los que fueran consagrados por la experiencia histórica de los amos de la tecnología" 24

Para introducir la crítica al modelo difusionista, debemos conocer las críticas a las teorías del desarrollo que la hicieron posible. Es en los años sesenta que emerge una respuesta propia, latinoamericana, al desarrollo programado e impuesto por los estados nacionales dominantes. Varios economistas, intelectuales y trabajadores de la comunicación avanzan sobre los límites del progreso capitalista, para pensar en otro modelo, con otros horizontes. Se agrupan en las teorías de la dependencia, que buscan descifrar los sustentos últimos del desarrollismo, conceptualizando "centro" y "periferia" como una relación desigual, donde el "desarrollo" es el paradigma que mantiene la marginalidad de los países periféricos, haciendo sustentables las economías de los países ya "avanzados". Andre Gunder, uno de los teóricos de la dependencia, denuncia que el desarrollo y el subdesarrollo son las dos caras opuestas de la misma moneda (Andre Gunder, 1967). Los países desarrollados logran su bienestar económico gracias a la industrialización de las materias primas extraídas del mundo subdesarrollado, con poco valor agregado; así controlan el flujo y comercio de los bienes manufacturados. Este movimiento intelectual sostiene que las recetas que se aplicaron en los países subdesarrollados no son las mismas que llevaron a cabo en los países dominantes. Al entrar en jaque los argumentos de las teorías del desarrollo, sus mecanismos, técnicas y metodologías de investigación e intervención son por ende cuestionadas y revisadas bajo el espíritu detallado.

El antropólogo colombiano Arturo Escobar es una voz referente con respecto al desencanto del "desarrollo" que se vivió y vive en lationamérica. En su texto La invención del Tercer Mundo, construcción y deconstrucción del desarrollo propone narrar la historia de esa ilusión del desarrollo,

24 Mattelart, Armand - Multigner, Gilles. La comunicación-mundo: historia de las ideas y de las estrategias. Siglo XXI Editores. Pág. 20 
66...de aquel sueño, y de cómo poco a poco se convirtió en pesadilla. Porque en vez del reino de abundancia prometido por teóricos y políticos de los años cincuenta, el discurso y la estrategia del desarrollo produjeron lo contrario: miseria y subdesarrollo masivos, explotación y opresión sin nombre."25

Destaca en su obra los síntomas del fracaso de la implementación de políticas de desarrollo en Latinoamérica: la crisis de la deuda, la hambruna, la creciente pobreza, desnutrición y violencia. (Escobar, ob. cit.)

Al ser criticado el modelo, sus dispositivos privilegiados entran en debate y reformulación. Tal caso no fue ajeno a la comunicación rural. Pero es desde el campo de la educación popular donde se encaminan los aportes críticos más valiosos, hacia la comunicación funcional del modelo del desarrollo impuesto. Es Paulo Freire, el pedagogo brasilero, quien escribe para finales de la década del 60, un texto que descifra el quehacer comunicacional de los servicios de extensión rural. La comunicación rural recibe desde este trabajo, la sostenida invitación a despojarse del desarrollo impuesto, de sus mecanismos de persuasión y divulgación de paquetes tecnológicos, para proyectarse en tanto encuentro, diálogo para la transformación social.

Con su experiencia a cuestas de su método de alfabetización llevado a cabo con trabajadores rurales y campesinos en Brasil, debe emigrar hacia el exilio. Pasando por Bolivia, termina quedando a trabajar en Chile donde colabora con el Movimiento Cristiano para la Reforma Agraria. En este contexto crítico, de repensar los límites y posibilidades del mundo agrario, escribe “Extensión o Comunicación” la concientización del medio rural, dando cuenta de nuevos horizontes de una relación en construcción entre el técnico de territorio y el campesino. Además de ser un tratado de educación popular, es en sí, un ensayo que revalora las posibilidades de una comunicación al servicio de los pueblos. Su primera edición en castellano data de 1973.

Propone desandar la estructura y funcionamiento de esta relación técnico agrario campesino, desde una aproximación semánticamente al término extensión, denunciando un equívoco gnoseológico. "Extensión” en su sentido contextual es la acción de extender algo hasta alguien, y el extensionista agropecuario busca por ende, extender sus conocimientos y sus técnicas hacia los pobladores rurales.

25 Escobar, Arturo. La invención del Tercer Mundo construcción y deconstrucción del desarrollo. Editorial Norma.1996. 
La riqueza del análisis que recorre el texto radica, en que logra centrar su atención en la práctica de la extensión, sin desviar la crítica al macro-modelo de producción industrial del agro en Latinoamérica que la sostiene como tal. Desde esta relación mecanicista entre sujetoobjeto, descifra el proceso impuesto del desarrollo y su modelo de acumulación del capital. De allí que postula, que no hay técnica neutra, todo debe ser tenido en cuenta, en su relación con los condicionamientos socio-culturales del proceso socio-histórico en cuestión.

Intentando relaciones asociativas sobre la unidad lingüística “extensión”, logra pensarla en tanto: transmisión, mesianismo, donación, superioridad, mecanicismo, invasión cultural, manipulación. Declara que el técnico es el sujeto activo de esta relación dispar, quien define el contenido de esta interacción, transformando al otro como objeto de su intervención, como depositario de sus saberes.

“... al establecer sus relaciones permanentes con los campesinos, el objetivo fundamental del extensionista, en el trabajo de extensión, es intentar hacer que ellos cambien sus conocimientos asociados a su acción sobre la realidad, por otros, que son los conocimientos del extensionista, para sí lograr la sustitución de sus formas de enfrentar la naturaleza",26

Este modelo de comunicación silencia e invisibiliza todos los conocimientos del campesinado, lo que en términos de Bourdieu podríamos denominar el ejercicio de la violencia simbólica, al imponer una visión del mundo, de las categorías cognitivas, de los roles sociales, y de las estructuras mentales (Bourdieu, 1972). Pero, si es que se va a llevar a cabo una reforma agraria, es ineludible la necesidad de reformar el modo de producción de conocimientos para trabajar con la naturaleza.

"He ahí, en el proceso de reforma agraria, el quehacer fundamental del agrónomo: más que un técnico, frio y distante, es un educador que se compromete y se inserta, con los campesinos en la transformación, como sujeto, con otros sujetos." (ob. Cit. pág. 71)

Revalorando la dimensión cultural de donde se interviene, Freire construye un modelo superador del extensionismo. Frente a este esquema de intervención antidialoguista, emerge en su obra el diálogo para una educación liberadora, la comunicación para el humanismo verdadero, que permite vivenciar el diálogo. "Ser dialógico es no invadir, es no manipular, es

26 Freire, Paulo. ¿Extensión o Comunicación? La concientización del medio rural.Siglo XXI Editores. 1973 
no imponer consignas. Ser dialógico es empeñarse en la transformación, constante de la realidad" (ob. cit. pág 46)

Haciendo un contrapunto con la concepción biográfica y lineal de la historia, como evolución hacia etapas de madurez, y contestando los estigmas que sufrieron los saberes populares y las sociedades no modernas, en las teorías del desarrollo, Freire propone construir un nuevo modelo de relación técnico-campesino profundamente enraizado en las condiciones existenciales de los campesinos, de su visión cultural, de sus creencias, partiendo "del nivel en que se encuentran, y no de aquel, que el agrónomo juzga deberían estar” (ob.cit. pág. 103)

Por último propongo valorar la forma en que Freire entiende a la producción de conocimientos, inaugurando un constructivismo social. Como pedagogo, podríamos ubicarlo en relación con el modelo constructivista (Vigotsky), pues en su obra queda claro que el conocimiento se construye; pero logra ampliar este enfoque, al resignificar y ubicar el aprender-haciendo como proceso colectivo. Se construye conocimiento auténtico y liberador necesariamente con otros. "No hay pensamiento aislado, así como no hay hombre aislado" (ob. cit. pág 74) En esta epistémica social, la comunicación es necesaria, pues cimienta las bases de la producción del sentido, en tanto diálogo problematizador. Bien haríamos en remarcar que en toda su propuesta pedagógica, "la educación" y "la comunicación”, se entrelazan, son arena del mismo costal.

\footnotetext{
"La educación es comunicación, es diálogo, en la medida en que no es la transferencia del saber, sino un encuentro de sujetos interlocutores, que buscan la significación de los significados." (ob. Cit. pág.77)
}

Con Freire, la comunicación rural muta de una propuesta persuasiva de modificación de conductas y conocimientos, de adaptación de la ruralidad latinoamericana a la racionalidad productiva del proyecto de modernización del capitalismo occidental, para ser entendida como un proceso comprometido socialmente, que partiendo del pronunciar entre todos el mundo, los hombres pueden empezar el camino de transformarlo. La comunicación es el componente de un proyecto de humanización para todos, un movimiento revolucionario.

Detenernos en el mundo del contexto rural, no implica apartar los aportes de otras teorías que pensando desde públicos y audiencias interpeladas de modo masivo, permitieron avanzar a nivel conceptual y direccional en el campo de la comunicación. Por ejemplo, los trabajos que entran en relación con las teorías de la Dependencia (Imperialismo Cultural). Estos 
aportes interactuaron con los pensadores de la comunicación rural y promovieron así nuevas perspectivas de acción e intervención (Pasquali, Beltrán, Marques de Melo, Gutiérrez, Lousa da Fonseca, entre otros.)

Cabe entonces la mención para las teorías críticas de la comunicación, que permitieron desnudar la estructura y contenido de los flujos de información, la concentración internacional de la comunicación (Muraro, Pasquali); develar la producción cultural como mercancía, la racionalidad instrumental de la tecnología, desde donde se busca la reproducción de las ideologías dominantes (Escuela de Francfort); como así también cabe mencionar a los estudios que pensaron la relación cultura-comunicación (Escuela de Birmingham). Teorías que habilitaron la desfragmentación del massmediacentrismo, para ir en busca de una comunicación como producción social del sentido, como hecho cultural. (Martín-Barbero, Mata, García Canclini)

A diferencia de los primeros ejemplos de la comunicación al servicio del "progreso" desarrollados en este trabajo, estas teorías que irrumpen sobre lo establecido, problematizan los contextos sociales latinoamericanos, analizan las lógicas de reproducción de las desigualdades, descifran las tramas de poder y su relación con los medios y soportes masivos de comunicación (Muraro, Pasquali, Mattelart, Wolf, Schmucler). Muchos de los escritores de estos estudios estuvieron comprometidos en lo social y lo político.

Sumando estos aportes propongo ir en búsqueda de otro investigador que mucho tuvo que ver con la comunicación rural, hablamos de Juan Díaz Bordenabe, de Paraguay; quien cumplía con una doble condición profesional: era agrónomo y comunicador. Aunque es difícil igualar un aporte tan sostenido como el de Freire en la comunicación rural, Díaz Bordenave habilita nuevas aristas críticas al quehacer comunicativo en la intervención rural. Al igual que otros investigadores y trabajadores de la comunicación en los años '60, y formados en los posgrados de las universidades norteamericanas, al constatar la teoría importada y la realidad latinoamericana, produjeron un giro crítico en sus enfoques sobre el desarrollo. En su obra “QQué es la Comunicación Rural?” de Díaz Bordenave reconocemos una descripción exhaustiva de cinco modelos de intervención y propuesta de comunicación de persuasión, de extensión y de comunicación existentes en Latinoamérica. Estas son:

El difusionismo: "entiende que el desarrollo ocurre cuando se introducen entre los agricultores nuevas ideas de mayor eficiencia productiva. [...] La campaña se 
convirtió así en el método básico de la información rural difusionista, que consistió en el uso combinado, intenso y concentrado de mensajes y medios en una región limitada, a fin de conseguir que un determinado grupo objetivo adopte su comportamiento deseado"

Modelo de paquetes: "afirma que más que difundir un paquete de técnicas, como lo defiende el modelo difusionista, deberá ser colocado al alcance de cada productor un paquete de servicios"

Modelo de innovación inducida por el mercado: donde "el mecanismo de mercado es definido como el principal factor determinante de la dirección que tomarán las innovaciones agrícolas [...] Si se pretende que el mercado demande la producción de tecnologías más apropiadas y cambios institucionales más relevantes para el desarrollo de la población rural, el sector público tendrá que invertir en la modernización de los sistemas de comercialización y comunicación”.

Modelo de organización/participación: frente a los problemas que viven amplios sectores del espacio rural: las reacciones coinciden en la absoluta y urgente necesidad de modelos de desarrollo rural, orientados hacia el bienestar de la población, y en los cuales ella tenga una importante participación en la toma de decisiones [...] La comunicación se convierte en una fuerte aliada de la promoción de la organización de los agricultores y, una vez lograda, facilita la cohesión de la clase y la expresión de sus aspiraciones, opiniones y demandas".

Modelo de transformación estructural: "la participación organizada de la población rural, que en el modelo anterior era más un instrumento de diálogo para lograr una mayor eficiencia de las medidas oficiales de la política agraria, en este modelo se convierte en un camino de desarrollo de la conciencia crítica y de adquisición de poder, aumentando progresivamente la autonomía decisoria de la población organizada y fortaleciendo su influencia soberana sobre los centros neurálgicos del Estado [...] Las funciones de la comunicación rural adquieren su máxima expresión de diálogo y de participación en esta perspectiva transformadora" (Díaz Bordenave en Prieto Castillo, 1994) ${ }^{27}$

En su texto Introducción a la Comunicación Rural, Daniel Prieto Castillo advierte que vivimos un proceso en donde no se ha agotado ninguno de las cinco alternativas. "En efecto, hay instituciones centradas todavía en el difusionismo, en tanto que otras se mueven en la innovación inducida por el mercado o en intentos de transformación estructural"28

Si Freire fue y es, para muchos extensionistas y comunicadores rurales un aporte difícil de llevar a la práctica, "poco operacionalizable”, Díaz Bordenave es un instructor metódico. A

27 Prieto Castillo, Daniel Una introducción a la comunicación rural. Ediciones INTA. Buenos Aires. 1994. pág. 14

28 Prieto Castillo, Daniel Una introducción a la comunicación rural. Ediciones INTA. Buenos Aires. 1994. pág. 14 
lo largo de toda su obra, Díaz Bordenave desanda e incurre su aporte en guías de pasos. Este aspecto más esquemático, lo hizo más conocido en los servicios de extensión rural de Argentina.

En sintonía con su debilidad por diseñar y conocer estructuras operativas de intervención educativa-comunicacional en lo rural, se encuentra y adopta el esquema del arco de Maguerez $^{29}$. Esta fórmula de trabajo la conoce cuando en los años `70, el educador rural francés, Charles Maguerez, capacita a los técnicos agrarios de extensión de Brasil. El método busca mediar entre el saber científico y el saber popular, intentando una educación problematizadora de cinco etapas ${ }^{30}$, i) la observación de la realidad, para partir de experiencias vividas con respecto al problema planteado, ii) los puntos clave a desarrollar, acordados entre todos los participantes, iii) el momento de teorización, donde se analiza la estructura y las causas del problema, iv) el diseño de las hipótesis de solución; v) y por último su aplicación a la realidad. Momentos todos de un espacio de encuentro entre productores rurales y técnicos agrarios.

Por último, en lo que respecta a este período de reformulación y crítica de las bases de la comunicación en ámbitos rurales, es necesario recordar la obra del sociólogo Joao Bosco Pinto, sus reflexiones ${ }^{31}$ y prácticas sobre la educación de adultos y la organización campesina, desde donde trabaja y propone la "investigación participante"32 como método de concientización rural, dando entidad a la comunicación como pedagogía del cambio. ${ }^{33}$

Los proyectos de comunicación alternativa, popular, dialógica cuando estaban

29 Maguerez, Charles. Análise do sistema paulista de assistencia a agricultura. Campinas, Relatorio de Assistencia prestada à Cordenadoria de Assitencia Técnica Integral (CATI), 1970.

30 Díaz Bordenave, Juan. El método del arco, una forma de hacer educación problematizadora. Edición Decisio Educación Pupular. 2005

31 Bosco Pinto, Joao: "Extensión o educación": una disyuntiva crítica, Instituto Interamericano de Ciencias Agrícolas Zona de las Antillas: Santo Domingo, 1977

Educación Liberadora, dimensión teórica y metodológica. Ediciones Búsqueda. Buenos Aires. 1976.

32 Junto a Fals Borda (Colombia) son considerados los pioneros de la investigación acción participativa en Latinoamérica.

33 Atendiendo lo implícitamente sesgado que todo trayecto tiene, y reconociendo los aportes no trabajados en este recorrido, cabe por lo menos mencionar los realizados en este período por Francisco Gutiérrez, Rosa María Alfaro, María Cristina Mata, Fernando Reyes Mata, Mario Kaplún; como también resaltar los trabajos del comunicador boliviano Luis Ramiro Beltrán, qué en su extensa obra logra historizar y aportar los estudios de la comunicación latinoamericanos relacionados a las prácticas y críticas del desarrollo. En ella Beltrán busca promover el encuentro entre las diversas prácticas, corrientes y conceptualizaciones que surgieron a partir de la crítica del modelo difusor en Latinoaemrica. 
emergiendo y reconociéndose con fuerza, vieron amenazada su expansión con el abrupto surgimiento de gobiernos militares en el continente. Este proceso dictatorial, fragmentó estas experiencias, desarmó muchos proyectos e instancias de comunicación participativa, y las obligó, a las que pudieron mantenerse pese a todo, a sobrevivir en la clandestinidad.

\section{Después del silencio}

Las teorías de la comunicación en Latinoamérica, entrados los años '80 logran enfocar el trabajo desde lo cultural como arena de disputa del sentido, dejando así de lado la tensión desarrollo-dependencia, y por ende la extensión como modelo de intervención y comunicación. Desatendida la opción extensión o comunicación, muchos proyectos rurales, y con el mismo espíritu modernizador que dio origen a esta práctica de intervención del desarrollo, incorporaron técnicas y dinámicas participativas y de "educación popular", tan sólo para hacer más digerible y eficaz la adopción de nuevas tecnologías científicas, vaciando así de contenido transformador el concepto de "participación"34. Emergen aquí las publicaciones tendientes a reducir la comunicación a técnicas y procedimientos de fácil uso para el trabajo de intervención, promovidas por las agencias de cooperación y de financiación multinacional.

La comunicación rural en los últimos años no logró avanzar como joven disciplina, en el debate difusión-comunicación, ni planteó nuevos desafíos teóricos relevantes. A mi entender, hay varios aportes valorables, pero que no conforman una propuesta sólida de nuevos modos de hacer-pensar la comunicación en lo rural. Tal vez una iniciativa a destacar de estos últimos años, que provee reflexividad sobre las estrategias de intervención en la ruralidad, son los trabajos del profesor Jorge Huergo; quién retomando los postulados de Freire consigue acercar la perspectiva cultural a los procesos de extensión y comunicación rural. Define a la cultura en tanto conjunto de estrategias para vivir, en tanto campo de lucha por el significado de la experiencia, de la vida y del mundo; y propone así, un nuevo enfoque del trabajo de extensión que debe partir de una investigación y reconocimiento del mundo cultural rural. ${ }^{35}$

Los años venideros, a partir de la implementación del neoliberalismo, a mediados de los

34 Esto se desarrolla en el Componente II.

35 Huergo, Jorge Desafíos a la extensión desde la perspectiva cultural. Revista Dialoguemos. Ediciones INTA. 2004 
‘70 por gobiernos militares en Latinoamérica, signó un espacio de vacío y desfragmentación de las propuestas críticas de una comunicación rural popular.

\section{Neoliberalismo, Agronegocio y Ciencia. Tramas de una acumulación por desposesión}

Propongo ahondar en el proceso de implementación del paradigma neoliberal en la Argentina a través de tres ejes: neoliberalismo, agronegocio y ciencia; prestando especial atención a la reestructuración del mundo rural, y los sistemas e institutos científico-técnicos abocados a ella; para de esta manera describir y conocer los postulados socio-históricos que transformaron el quehacer comunicacional del INTA en los últimos 30 años.

El descifrar y analizar los paradigmas, matrices y enfoques que operan y atraviesan las prácticas, decisiones y discursos en el territorio desde donde trabajo, es un paso primordial para lograr cualquier intervención e investigación social. Dar cuenta de un diagnóstico crítico e integral, en tanto cultural, socio-histórico y económico-político, es apostar a la construcción de un conocimiento ampliado, relacional y estratégico para la toma de decisiones y la planificación de procesos comunicacionales.

\section{Neoliberalismo}

Con la crisis de los Estados Promotores y del desarrollismo nacional, profundizada en 1973 a partir de la suba del precio del petróleo mundial, insumo vital para el esquema del capitalismo nacional industrial, por parte de la OPEP (Organización de Países Exportadores de Petróleo), se inaugura la era de políticas neoliberales. Hablamos de neoliberalismo en tanto paradigma macroeconómico, en tanto modelo societal, que emerge y se impone como única respuesta posible a la crisis de acumulación del capital de los '70.

Sus inicios teóricos se ubican después de la segunda guerra mundial en Europa y 
Estados Unidos, ${ }^{36}$ y surge como respuesta teórica y política contra la intervención del Estado en las decisiones macroeconómicas, y en otras órdenes sociales y políticas. Criticando los postulados del capitalismo nacional productivo, se construyó la idea de un Estado que en esencia era contrapuesto a la libertad económica y política de una nación. Esta reestructuración del orden global, fue impulsada e impuesta por los organismos multilaterales de crédito agrupados en el Consenso de Washington, el Fondo Monetario Internacional (FMI), la Organización Mundial del Comercio, y el Banco Mundial; que a través del endeudamiento público que los países contraían con los organismos, éstos encontraban los mecanismos para orientar, cuando no, disciplinar sus políticas nacionales y dietas presupuestarias.

El neoliberalismo fue el paradigma de reposición, que venía a solucionar los problemas de la recesión e inflación que vivían los países latinoamericanos en 1970. El mismo, partía de la base del libre mercado, sin actuación del Estado. El Estado debía focalizar en su capacidad de control de las políticas monetarias, disminuyendo su intervención en lo económico gradualmente, a la vez que su inversión social. El Estado delegaría la mayoría de las funciones y roles que supo tener, exceptuando la tarea del uso de la fuerza coercitiva, su función de policía.

El actor protagonista que fue conformándose en este período y que disputó el esquema de poder mundial, fue la empresa multinacional, logrando equiparar su poder con el de los estados dominantes, cuando no, lo superó. Los estados neoliberales acomodaron sus leyes de inversión y regulación a favor de despejar cualquier obstáculo que impidiese el libre ingreso de los actores económicos transnacionales financieros. La apertura de la economía desde la baja de restricciones arancelarias e impositivas a las importaciones y a los flujos de capital financiero, fue la medida que permitió la expansión de los agentes del capital trasnacional.

Entre otros ejes relevantes de este proyecto, se dieron la ejecución de regulaciones y políticas monetarias restrictivas, la disciplina presupuestaria, las reformas impositivas regresivas, la flexibilización y precariedad laboral, y la privatización de bienes públicos y sociales. Promocionando el desmantelamiento de las políticas estatales del pleno empleo, el sindicato como eje de peso en la tensión trabajo -capital, fue la organización a comprimir en

36 Podemos ubicar los orígenes teóricos del neoliberalismo en la obra Camino de Servidumbre de Friedrich Hayek, escrito en 1944. 
estos años.(Anderson, 1997) $)^{37}$

El historiador de origen inglés, Perry Anderson da cuenta de dos fases sucesivas de políticas neoliberales en Latinoamérica. La primera llevada a cabo por el terrorismo de Estado, las dictaduras conservadoras, y la segunda fase en períodos de democracia, donde no era necesaria ya la implementación del modelo por la fuerza, sino que se postulaba frente a la presión y amenaza constante de la hiperinflación. Podemos decir que el primer laboratorio de experimentación del neoliberalismo fue en Latinoamérica, más precisamente en Chile, bajo la dictadura de Pinochet en 1973.

En Argentina podemos ubicar el surgimiento del neoliberalismo en el gobierno militar instaurado en 1976 autodenominado Proceso de Reorganización Nacional. Desarticulando y diezmando todo movimiento social y obrero, se liberó el mercado y facilitó el ingreso del capital financiero como ordenador económico al país. Se promovió la importación frente al consumo interno autónomo, desestabilizando el parque industrial que quedaba del "capitalismo de estado". La deuda externa se incrementó para cubrir los déficits públicos y de las empresas privadas. Coincido con algunos autores que por la tradición que nuestro país tenía en tanto un Estado presente en la economía, en las políticas sociales, fue sólo posible la implementación de las medidas neoliberales a través del terrorismo de Estado, que reprimió, persiguió y desapareció a los referentes y militantes sociales. Por esos años se acuñó una frase que guió todo el espíritu de las políticas públicas: "Achicar el estado es agrandar la Nación”.

La segunda fase de profundización del modelo neoliberal se da bajo gobiernos democráticos, a partir de principios de los '80, donde se llevó a cabo una reforma del Estado, y todo fue medido en su eficacia económica y tasa de ganancia. En este esquema el Estado debía regirse en el principio de subsidiariedad, en tanto actuar e intervenir en los casos de extrema pobreza, o donde los logros del mercado no lograban penetrar. Fue durante la democracia donde se expandió el modelo a través de las privatizaciones de las funciones, empresas, bienes y servicios de origen públicos. El Ministro de obras públicas, Roberto Dromi, quien se autodefinía como el "gerente de las privatizaciones", en casa de gobierno una tarde de 1989, anunciaba junto al presidente de la nación Carlos Menem, y su vicepresidente Eduardo

37 Anderson, Perry "Neoliberalismo: un balance provisorio", en Sader, Emir, gentili La trama del neoliberalismo. Mercado, crisis y exclusión social (Buenos Aires: Oficina de publicaciones del CBC-UBA) $1^{a}$ edición. Pág. 15-27. 1997 
Duhalde los ejes de la reforma del estado:

"El gobierno de la nación argentina cumplimenta esta noche siete cabalísticas privatizaciones, siete sectores estratégicos del quehacer nacional. Encaramos las privatizaciones de la televisión, de los teléfonos, de instalar el sistema de peaje, de instalar la concesión vial o la concesión ferroviaria, también de privatizar las radios, el de incorporar por supuesto la privatización de empresa estatal de la aeronavegación. Nosotros hemos ideado el Decálogo Menemista de la reforma del estado, el mandamiento uno dice así: nada de lo que deba ser estatal permanecerá en manos del estado"

Y así fue, la Argentina llevó a cabo el proceso más intenso del modelo del neoliberalismo de toda América Latina, y fue expuesto por sus ideólogos como el ejemplo a seguir en todas partes del planeta. En esos años '90 se privatizaron los teléfonos, los canales de televisión abierta, las radios AM y FM, el correo, la aerolínea de bandera nacional (Aerolíneas Argentinas), los aeropuertos, los servicios ferroviarios, la petrolera YPF (Yacimientos Petrolíferos Fiscales), el gas natural, la electricidad, el agua potable, el espectro radioeléctrico, dos siderurgias, la concesión de caminos (surgimiento de peajes), el Mercado de Hacienda de Liniers y la seguridad social previsional.

La dictadura argentina a través de sus mecanismos represivos, y sus valores societales logra desmantelar las organizaciones libres del pueblo, diezma el movimiento sindical popular, desarma la articulación del espacio público, quebrando lazos sociales establecidos. Con el advenimiento de la democracia, y entrados los años '90 el individualismo ontológico es el paradigma cultural promovido.

"La influencia de un paradigma individual-competitivo muestra el pasaje de un modelo cultural vinculado a lo público estatal de solidaridades nacionales hacia otro vinculado al mercado, a la sociedad civil y competencia. La amplia socialización de valores individualistas, narcisistas, en el seno de la sociedad de consumo y el impacto desmovilizador de la crisis desplazan el centro de atención ideológico del ámbito público al privado y de la acción colectiva al espacio de la privacidad" (García Delgado, 1994: 62)

Vemos emerger la estigmatización del mundo de la política, en tanto ineficiente y corrupto, frente a la iniciativa privada que aparece "como la esfera de la eficiencia, la probidad

38 García Delgado, Daniel. Estado y Sociedad. Tesis Norma. Buenos Aires 1994, pág. 62 
y la austeridad" (Borón, 1999) ${ }^{39}$ Este etnocentrismo se expande a través de las lógicas del consumo neoliberal. La identificación social, ya no se da en el sentido de pertenencia cultural o social, sino que opera en términos de los consumos. Los lazos comunitarios se van debilitando, los espacios de encuentro e interacción social mercantilizando. El profesor y activista cultural Karlos Santamaría diagnostica que las relaciones personales han ido desapareciendo y las mismas han sido sustraídas, en gran parte por relaciones económicas" 40 Podemos decir que toda esfera social, cultural, identitaria sufre el reduccionismo económico. Harvey sostiene que se ha producido "la mercantilización de las formas culturales, las historias y la creatividad intelectual" (Harvey, 2004) ${ }^{41}$.

Esta etapa del capitalismo mundial es conocida como globalización, una interrelación económica, primordialmente financiera, que logra una escala mundial de libre acceso a los mercados. La globalización es la disolución de las fronteras económicas a favor del capital trasnacional que interviene y ordena los mercados nacionales y regionales. El economista egipcio Samir Amin, hace uso del término "mundialización”, para descubrir lo que se pretende ocultar tras él, y así descifrar las lógicas de expansión del capitalismo y sus dimensiones imperialistas de su despliegue a las que refiere el término. Imperialismo y mundialización aparecen en tanto sinónimos del esquema neoliberal que reestructuró el mapa económico y de poder a nivel global, demandando el ingreso de los países periféricos a través del ajuste estructural. A la vez el mercado de capitales, avanza por sobre el mercado de productos, promoviendo la financiarización especulativa de las economías y el endeudamiento público, generando así una nueva división desigual internacional del trabajo.

En su texto, Capitalismo, Imperialismo, Mundialización, Samir Amin sugiere que las tendencias de la evolución del capitalismo contemporáneo, se articulan en torno al refuerzo de lo que ha llamado los "cinco monopolios" que caracterizan a la mundialización polarizante del imperialismo contemporáneo:

i) El monopolio de las nuevas tecnologías.

ii) El control de los flujos financieros a escala mundial.

iii) El control del acceso a los recursos naturales del planeta.

39 Boron, Atilio. "La sociedad civil después del diluvio neoliberal”, en La trama del neoliberalismo. Mercado Crisis y exclusión social, Sader y Gentilli. Clacso-Eudeba. Buenos Aires 1999, pág. 55.

40 Santamaría, Karlos (s/f): "El concepto de fetiche", en El Diario Vasco.

41 Harvey, David El nuevo imperialismo AKAL. Madrid. 2004 pág. 114 
iv) El control de los medios de comunicación.

v) El monopolio de las armas de destrucción masiva. (Samir Amin, 2001) ${ }^{42}$

Al proceso que Marx denominó como acumulación originaria o primitiva, David Harvey, geógrafo y teórico social, lo piensa en el capitalismo contemporáneo como la “acumulación por desposesión”. Los mecanismos de esta acumulación incluyen:

\footnotetext{
"la mercantilización y privatización de la tierra y la expulsión forzosa de las poblaciones campesinas;la conversión de diversas formas de derechos de propiedad -común, colectiva, estatal, etc.- en derechos de propiedad exclusivos; la supresión del derecho a los bienes comunes; la transformación de la fuerza de trabajo en mercancía y la supresión de formas de producción y consumo alternativas; los procesos coloniales, neocoloniales e imperiales de apropiación de activos ,incluyendo los recursos naturales." ${ }^{, 43}$
}

Como así también hallamos a la destrucción de activos a través de la inflación, la promoción del endeudamiento, el fraude corporativo, la propiedad intelectual. Harvey resalta el principal esfuerzo de acumulación por desposesión de estos últimos años, refiere a los llevados a cabo por los fondos especulativos de cobertura y otras grandes instituciones del capital financiero. Este proceso global, es definido por el autor como el nuevo imperialismo.

\section{Agronegocio}

El impulso neoliberal implicó la reestructuración del agro latinoamericano, promoviendo el agronegocio como esquema de rentabilidad. Este modelo del agronegocio, o como también ha sido llamado modelo de sojización, es la política agraria privilegiada del modelo neoliberal argentino. Esquema que se fue imponiendo a mediados de los '70, con regulaciones a favor del ingreso de capital trasnacional en la economía nacional, y la persecución a los dirigentes populares de las ligas agrarias, como primeros pasos. En sintonía con lo argumentado, podemos reparar que fue desde el seno de la Sociedad Rural (organismo que agrupa a los actores concentrados del agro y la ganadería argentina), que salió el ministro

42 Amin, Samir “Capitalismo, imperialismo, mundialización”, en Seoane, Taddei, Resistencias mundiales. De Seattle a Porto Alegre (Buenos Aires: CLACSO), pp 15-29. 2001

43 Harvey, David El nuevo imperialismo AKAL. Madrid. 2004 pág. 113 
de economía y principal ideólogo del esquema neoliberal de la dictadura, José Alfredo Martínez de Hoz.

Fue en los '90 que se profundizó este modelo de producción rural, donde se desreguló la actividad de la carne, los granos y el azúcar, y se autorizó el uso de los paquetes tecnológicos de semillas y materiales transgénicos. El ingreso del capital financiero, fue más agresivo y logró postularse como el actor dinamizador y organizador de la economía agraria. Entre los mecanismos de actuación del capital financiero se encuentran los pools de siembra, que se establecieron en Argentina en esta segunda fase de consolidación del modelo neoliberal. El sistema "pool" (colecta) se basa en lograr un fondo común de inversión para alquilar grandes extensiones de campo, sembrar plantaciones cuyos granos tengan un alto precio internacional, aplicar tecnología genética (semilla-fumigación-fertilizantes), para después dividir las ganancias de acuerdo a la inversión.

La agricultura promovida por este esquema de negocio financiero refuerza el monocultivo de cereales y oleaginosas industriales ${ }^{44}$, y su colocación con escaso o ningún valor agregado en el mercado internacional de valores. Así los fondos de especulación decidían que sembrar de acuerdo a la fluctuación internacional del valor de los granos. A través de paquetes tecnológicos producidos mayoritariamente por empresas trasnacionales, se logra una ampliación de la frontera agrícola argentina, habilitando nuevas tierras en el país, donde hasta hace poco era imposible pensar en una siembra.

El paquete tecnológico, comprende el desarrollo genético de nuevas variedades de semilla, nuevas tecnologías de siembra, agroquímicos "eficientes" para la protección de los cultivos y nuevas maquinarias de cosecha a gran escala. La idea que subyace es maximizar la producción de granos y cereales por hectárea, y lograr que los cultivos tengan un comportamiento uniforme, para ajustar y acelerar los tiempos de crecimiento. Este desarrollo tecnológico fue producido y comercializado por empresas de capital trasnacional como Cargill y Monsanto ${ }^{45}$. Sus productos abarcan todo el proceso de producción de granos, desde la

44 Los principales cultivos expandidos estos años fueron: la soja, el girasol, el sorgo, el trigo, y el maíz.

45 Monsanto es la empresa de agronegocios más grande del mundo, presente en 46 países, controla el 20 por ciento del mercado mundial de semillas transgénicas y es líder en la venta de agrotóxicos. En sus 108 años de existencia impulsó el uso del PCB (elemento cancerígeno utilizado en transformadores eléctricos), fue proveedor en la guerra de Vietnam del químico "agente naranja" (utilizado por las tropas estadounidenses para arrasar el territorio enemigo) y cuenta con un centenar de denuncias por afectar el ambiente y la salud de campesinos e indígenas. (Darío Aranda. Periodismo y denuncia. Página 12. Diálogos Lunes 30 de marzo 
preparación del suelo hasta la cosecha, generando así una dependencia tecnológica por parte de quienes la adquieren.

Los productos que comercializan estas corporaciones, son de uso conjunto y simultáneo, de ahí que se conforma como paquete tecnológico. Uno no puede comprar un solo producto de la cadena, pues modifica el rendimiento del cultivo y sus resultados. El núcleo duro del paquete está en las semillas modificadas genéticamente para resistir nuevas agresiones climáticas, y en los agroquímicos (herbicidas, pesticidas, fertilizantes) que actúan para potenciar estas plantas. Todo cultivo toma del suelo donde se sembró, ciertos nutrientes para lograr su crecimiento, y toda vegetación y planta que va creciendo a su costado compiten por este alimento con él. Estas "malezas" dificultan el potencial de crecimiento del cultivo, por lo cual es necesario eliminarlas para obtener mejores resultados productivos. Las corporaciones lograron transformar las semillas para que sean resistentes a un específico herbicida que ellas mismas producen. De ahí, que las plantas de semilla transgénica pueden resistir al herbicida químico, mientras que las "malezas" de su alrededor mueren con la aplicación del herbicida. Con lo cual en este esquema de grandes extensiones de un solo cultivo, es más rentable la aplicación de este mecanismo, vía fumigación aérea, que el realizar las antiguas labores mecánicas y manuales de "desmalezamiento".

El circuito virtuoso de excedentes de estas corporaciones se da en tanto la venta del paquete tecnológico íntegro (semillas, agroquímicos), y el patentamiento de estos materiales, que impone un consumo continuo para con la tecnología. Amparándose en los derechos de propiedad intelectual $\left(\right.$ Tripps $^{46}$ ) de los materiales genéticos, y reclamando una seguridad biológica, estas corporaciones vienen desarrollando estudios e investigaciones para lograr restringir el uso de semillas modificadas genéticamente. Tal es la investigación en avance de una tecnología GURT (Genetic Use Restriction Technology ${ }^{47}$ ) o “Terminator”, como es coloquialmente denominada, que se está desarrollando desde los años '90 principalmente en Estados Unidos, y aunque aún no se comercializa, varias organizaciones y movimientos sociales están alertando sobre esta posibilidad; pues esta tecnología en proceso, a grandes rasgos, busca alterar genéticamente las semillas, para que de las plantas generadas desde esas

\footnotetext{
de 2009)

46 Acuerdo sobre los Aspectos de los Derechos de Propiedad Intelectual Relacionados con el Comercio.

47 acrónimo inglés de Grupo de Tecnologías de Restricción de Uso
} 
semillas, no se puedan obtener nuevas semillas para la próxima siembra (como sí se hace en el sistema tradicional agricultor); o que las semillas que broten sean estériles; o no sean más inmunes al agroquímico vendido.

Este paradigma del agro, permitió en Argentina una profundización en la concentración de la tenencia de la tierra en pocas manos, ya que la diferencia de rentabilidad entre pequeños y medianos productores con los pools de siembra, los fondos de inversión o los históricos terratenientes fue abrupta. La rentabilidad del esquema se basa también, en la reducción de los costos de producción ya que al reindustrializar los procesos agrarios a través de los componentes tecnológicos, mecánicos (maquinarías de gran escala), se necesitan menos trabajadores rurales para más hectáreas.

Con este "avance" tecnológico, se aumentó considerablemente la cantidad de tierras cultivables y cultivadas, reemplazando varios emprendimientos de ganadería, lechería, y cosechas tradicionales. Las zonas que antes eran asumidas por sus calidades de suelo y sus componentes climáticos como no habilitadas para la agricultura intensiva, con estas nuevas tecnologías lograron incorporarse en este esquema agrario. La frontera agrícola se expandió en el territorio nacional.

Después de 30 años de aplicación, podemos reconocer que el modelo del agronegocio del capital trasnacional, produjo más fragmentación social, profundizando las desigualdades en el mundo rural. La precarización laboral, la falta de empleo, la deserción rural, los problemas de salud humana y animal ocasionados por el uso de agroquímicos, la degradación del suelo a causa del uso intensivo desde monocultivos, la depredación del medio ambiente y los bienes naturales comunes, son consecuencias directas del modelo trasnacional agrario.

Qué es lo que se va a producir en el país ya no responde a una planificación estatal o de emprendimientos privados nacionales sino, que es decidido por los agentes económicos de capital trasnacional en referencia con el precio internacional de los granos y su valoración en el mercado de capitales. Así, este modelo desarticuló y reestructuró al agro argentino, poniendo en crisis de oferta y precio la producción de materias primas para el sustento alimentario del mercado interno. Muchos movimientos sociales y autores coinciden en que el modelo del agronegocio, se contrapone a una propuesta de soberanía alimentaria (entre ellos $\mathrm{MCNI}^{48}$ ).

48 Movimiento Nacional Campesino Indígena. 
Dando cuenta de que la mayoría de las producciones son planificadas para ser colocadas en los mercados internacionales, y que las empresas nacionales de agro-alimentos fueron en su mayoría compradas y fusionadas por grandes corporaciones durante estos últimos años, la soberanía alimentaria se vio debilitada. La expulsión de campesinos y campesinas, y la deserción de muchas familias rurales afectaron a la producción de frutas, verduras, y carne para los mercados locales y regionales. Con lo cual, el sistema de producción y consumo interno de alimentos en estos años, se vio empobrecido y dependiente del sector financiero internacional. Si la soberanía alimentaria implica la autonomía para planificar y decidir sobre qué se va a sembrar y producir, teniendo en cuenta el bienestar de la población, el mercado interno, el cuidado de los bienes naturales comunes, como principal atención, el agronegocio saltea estas cuestiones nacionales, y se enfoca en la rentabilidad financiera.

\footnotetext{
"La reciente depredación de los bienes ambientales globales (tierra, aire, agua) y la proliferación de la degradación ambiental, que impide cualquier cosa menos los modos capital-intensivos de producción agrícola, han resultado de la total transformación de la naturaleza en mercancía.” (Harvey. op.cit. Pág 114)
}

\section{Ciencia}

A mediados de los años 70, con el surgimiento de políticas neolibeales, la ciencia y la tecnología tuvieron su reorientación en lo que se denominó la Revolución Científico Tecnológica (Argumedo, 2005 ${ }^{49}$ ), también considerada como la segunda revolución científico técnica, por quienes asumen como primera, a la revolución industrial. Esta plataforma científica fue uno de los ejes para instaurar un nuevo orden mundial, de hegemonía estadounidense, tras la crisis de los países de la órbita soviética, y la salida del modelo industrial. Esta ruptura de paradigma, permite el desarrollo de nuevas tecnologías de información, que convergirán para constituir una nueva matriz tecnológica-productiva, capaz de reemplazar gran parte de la mano de obra asalariada, de aumentar fuertemente la producción, reduciendo así los costos de

49 Alcira Argumedo. Crisis de las Ciencias Sociales de la Argentina en Crisis. Prometeo Libros. Buenos Aires 2005. 
manufactura y triplicando las ganancias. Algunos autores hablan de una nueva etapa societal, a la que llaman sociedad de la información y/o del conocimiento, donde el saber es una de las fuerzas claves y estructurantes de producción (Castellls, 2001 ${ }^{50}$ ).

Si bien ninguna rama científica quedó afuera de este proceso de mercantilización y fragmentación del conocimiento, podemos argumentar que fueron y son pilares de esta matriz las ciencias de la biología molecular-genética, con sus "nuevos materiales", y las ciencias de la información (transmisión y procesamiento de datos en tiempos descendientes). Los avances se vieron orientados desde la geopolítica (la carrera espacial y armamentística), desde el reordenamiento del mercado internacional tras la crisis del petróleo (telecomunicaciones, informática), y la baja de los costos de producción (incorporación de robótica, electrónica, biogenética, en la fabricación de productos de consumo masivo).

Hay una combinación en el modelo tecno-económico de la revolución microelectrónica de Estados Unidos y el modelo flexible de organización y gestión originado en Japón.(Araya, $2000)^{51}$ Se da así una transición de la producción masiva, “inflexible y homogénea (del fordismo), a esquemas productivos flexibles - en términos de productos y calificación de mano de obra- orientados a segmentos específicos de la demanda (toyotismo)" (Bisang, 1995) ${ }^{52}$

Podemos dar cuenta de esta transformación en nuestro país, al prestar atención a la academia y el auge de las universidades privadas, y la mercantilización de los conocimientos en las universidades públicas. Se fortalece y expande el imperativo financiero de corporativización de las estructuras de los sistemas e institutos científico-técnico. Una cantidad notable de funciones estratégicas de investigación pública, pasaron a ser gestionadas por empresas privadas. Y en aquellos estamentos que resistieron la privatización, no pudieron evitar los avances de la ciencia corporativizada. La ciencia al servicio del capitalismo trasnacional se sostiene en un conocimiento que es mercancía, y a la vez insumo básico para la reproducción del capital en el contexto de mundialización.

50 Castells, Manuel. La Era de la Información. Vol. II: El poder de la identidad. México, Distrito Federal: Siglo XXI Editores. 2001

51 Araya, José Maria Julio. La revolución Científico-Tecnológica. Claves para su comprensión y formas porsibles de afrontar sus efectos. En Ecos de Grado y Posgrado

52 Bisang, Roberto. Libremercado, intervenciones estatales e instituciones de ciencia y técnica en la Argentina: apuntes para una discusión. Redes, Vol. 2, Núm. 3, abril, 1995, pp. 13-58 Universidad Nacional de Quilmes 
En cuanto lo que veníamos desarrollando en este trabajo sobre la imposición a la fuerza del neoliberalismo, y el reordenamiento agrario que implicó, cabe mencionar la mutación de los fundamentos y supuestos teóricos en las facultades e institutos de ciencia y técnica agraria, tanto públicos, tal el caso del INTA (Instituto Nacional de Tecnología Agropecuaria).

Como desarrollaremos en el siguiente apartado, durante la última dictadura militar, el INTA fue intervenido, desfinanciado, sufrió los mecanismos de represión, y sus lineamientos se vieron modificados. Muchos integrantes del Instituto fueron cesanteados, otros, forzados al exilio, y algunos sufrieron la desaparición forzada. Se promovió la relación con los actores concentrados del agro, dejando de lado el trabajo con comunidades rurales. La relación entre los aspecto sociales, culturales y económicos del mundo rural se apartaron de los estudios y prácticas del personal profesional del Instituto. Toda alternativa al modelo de reprimarización del agro, y de un INTA al servicio de capitales concentrados fue silenciada. La investigación se focalizó en el desarrollo de tecnologías para la agricultura pampeana de exportación, y en la generación y transferencia de paquetes tecnológicos de los cultivos claves. (Gárgano, 2010) ${ }^{53}$

En el segundo momento de intensificación del modelo neoliberal (Anderson, op.cit. 1997), en la década de los '90, el INTA mantuvo su estatuto público, pero transfirió la mayoría de los avances científico-técnicos a las corporaciones privadas. Algunas organizaciones patronales agropecuarias promovieron la privatización del INTA, pero esta mala noticia quedó en el intento, aunque se reconoce que faltó poco para ello. Durante estos años el INTA vio disminuir su presupuesto drásticamente, y hubo muy pocos, casi ningún ingreso de profesionales y técnicos a su planta permanente. Gran parte del material genético estratégico que el INTA venía desarrollando desde sus inicios, fueron cedidos a empresas trasnacionales (como Monsanto y Nidera); a las que se les permitió, el acceso irrestricto a los archivos del Instituto. (Lapolla citado por Verbitsky, 2009) ${ }^{54}$ Las semillas modificadas genéticamente, producto de la investigación pública, eran comercializadas por actores privados de capital trasnacional, concentrando la oferta de semillas en el país.

Es en esta época, donde la gran mayoría de las facultades de agronomía, privadas y públicas, perfilaron sus componentes de investigación para adaptar el modelo del agronegocio,

53 Gárgano, Cecilia La reorganización de las agendas de investigación y extensión del Instituto Nacional de Tecnología Agropecuaria (INTA) durante la última dictadura militar (1976-1983). Ponencia. En Esocite 2010 Jornadas Latinoamericanas de Estudios Sociales de la Ciencia y la Tecnología. Buenos Aires. 2010 54 Lampolla, Alberto en Verbitsky El Predador, Página 12. 2009. 
y ampliar sus fronteras cultivables. Muchas de estas facultades hicieron contratos con empresas multinacionales en sus áreas de desarrollo e investigación científica. Entre tantos convenios podemos citar a modo de ejemplo, el llevado a cabo por la Universidad de Lomas de Zamora y una empresa multinacional de material transgenético. En el mismo documento se estipula el:

\begin{abstract}
"Convenio marco de Colaboración Técnica y Científica celebrado entre "MONSANTO ARGENTINA SOCIEDAD ANÓNIMA INDUSTRIAL Y COMERCIAL", y la Facultad de Ciencias Agrarias de esta Universidad Nacional. [...]Que de común acuerdo, La Facultad y Monsanto adoptarán programas de coordinación y cooperación para la ejecución conjunta, o a pedido de una de las partes, de estudios y/o proyectos de investigación en áreas o temas comunes. [...] IV Facilitar el intercambio de información científica y técnica de interés para ambas partes. V Co-participar en acciones que contribuyan a la promoción de la investigación científica y tecnológica."(Resolución 182-07 UNZ)
\end{abstract}

La mercantilización del sistema científico técnico nacional, se puede observar en el auge y cantidad de posgrados en la temática del agronegocio que dictan numerosas unidades académicas a lo largo del país.

Por último, cabe hacer referencia en este capítulo a cómo el paradigma neoliberal atravesó los estudios sociales. Las ciencias sociales vieron emerger estudios donde se promovía un reduccionismo económico en sus investigaciones, abriendo nuevas propuestas de management, marketing y gestión del conocimiento. Se puso énfasis en trabajos e investigaciones de las infraestructuras de información y comunicación al servicio de la eficiencia empresarial. Fue la empresa, como unidad organizacional y comunicacional, el objeto de análisis sociales, en donde se focalizó al individuo en su capacidad de consumo; así como también se profundizó la especialización y parcialización de los estudios sociales (Argumedo 2005, op.cit. Pág. 69), produciendo un distanciamiento entre la producción de conocimiento y los procesos socio-culturales en donde se formulan.

\footnotetext{
"Uno de los instrumentos más típicos de distorsión y encubrimiento de las realidades sociales ha sido el aislamiento de los hechos, eludiendo su vertebración en encuadres más amplios que muchas veces tienden a reformular sustancialmente el diagnóstico de una situación dada. No por casualidad las
}

55 Resolución №182-07 de la Universidad Nacional de Lomas de Zamora. Publicada en Los secretos de la universidad pública. Períodico MU. Cooperativa La Vaca. Buenos Aires. Marzo 2009 
vertientes de origen liberal son las que más enfatizan la parcialización en el análisis de los problemas históricos, económicos, políticos y sociales, negando la posibilidad científica de abordarlos desde una perspectiva en conjunto." ${ }^{56}$

Ignacio Ramonet, periodista español y director del movimiento ATTAC (Asociación por la Tasación de las Transacciones Financieras y por la Ayuda a los Ciudadanos) en una editorial de Le Monde Diplomatique ${ }^{57}$, apela y resignifica la idea de "pensamiento único", como la ideología dominante del neoliberalismo, que buscaba neutralizar todo postulado crítico, desprestigiando toda discusión ideológica y académica; pues un único pensamiento aceptable, y éste era el que derivaba del economicismo neoliberal.

“QQué es el pensamiento único? La traducción a términos ideológicos de pretensión universal de los intereses de un conjunto de fuerzas económicas, en especial las del capital internacional."(Chomsky, Ramonet. 1995) ${ }^{58}$

Se promociona así, la disociación en las ciencias sociales de los procesos económicos y la esfera política, promoviendo estudios, de ingeniería formal democrática, de ciudadanía, de formas y calidad institucional. Aquí surgen "las teorías de la transición democrática", que a partir de los 90`, coparon a las ciencias políticas en Latinoamérica. Este enfoque se basa en el análisis institucional, y postula a las democracias de los países dominantes como el modelo a imitar. Este enfoque otorga validez universal a una concepción simplificada de la democracia y el espacio público, a partir de una perspectiva liberal-democrática basada en la primacía de la libertad individual y la igualdad político-jurídica. (Burchart, 2008) $)^{59}$

\section{3- Neoliberalismo, comunicación y extensión. De la dictadura a la situación actual.}

56 Alcira Argumedo. Crisis de las Ciencias Sociales de la Argentina en Crisis. Prometeo Libros. Buenos Aires 2005.

57 Ramonet, Ignacio. La pensée unique. Editorial. Le Monde Diplomatique, 1995

58 Chomski, Noam; Ramonet, Ignacio. Como nos venden la moto. Información, poder y concentración de medios. Barcelona: Icaria. 1995. p.52.

59 Häns-Júrgen Burchart Desigualdad y Democracia Revista NUEVA SOCIEDAD No 215, mayo-junio de 2008, pág 80 . 
Como hemos visto en esta tesis, el modelo del "desarrollo" dio origen a los servicios de extensión rural y a la comunicación rural en Latinoamérica, y su primer impronta y trayecto estuvo marcada por el difusionismo. La divulgación de innovaciones fue el paradigma que gestó los estudios, prácticas y metodologías de la comunicación rural. Para llevar a cabo la tecnificación y adaptación del mundo rural argentino se constituyó el INTA, que respondía a los postulados de la Alianza para el Progreso. En los años '70, emergió un enfoque crítico hacia las políticas del desarrollo en América Latina, este enfoque atravesó todas las disciplinas sociales, políticas y económicas. Cuando estaba emergiendo y constituyéndose en contraposición al paradigma difusionista, fue censurado y acallado por las dictaduras militares. Dentro del INTA hubo un espacio para el modelo crítico dentro de la institución, que no logró conformarse y sostenerse por estas razones. Un grupo de extensionistas puso en relieve la estructura social del agro y sus desigualdades, promoviendo nuevos actores para disputar el modelo agrario vigente. Los extensionistas de mayor edad recuerdan algunos trabajos de extensión a nivel comunitario y popular, donde muchos de estas intervenciones buscaron acercarse a los aportes de Freire; como también se incorporaron a otras prácticas de extensión elementos de la teoría de la concientización, de la comunicación dialógica y de educación popular.

"El reconocimiento social con el que contaban los técnicos y extensionistas por parte de las comunidades rurales, estaba ligado con su fuerte presencia territorial. El contacto directo con las condiciones de existencia de las poblaciones rurales promovía que se instalara dentro de la tarea extensionista la reflexión en torno de qué transformaciones eran necesarias para el agro argentino." (Gárgano, 2010) ${ }^{60}$

Hubo espacios institucionales en donde se avanzó y profundizó esta mirada integral del mundo rural, (entre ellos la EPG -Escuela para Graduados de Ciencias agropecuarias- y los Programas de Estudios Económicos y Sociales) que buscaba reorientar la finalidad de las

60 Gárgano, Cecilia. La reorganización de las agendas de investigación y extensión del Instituto Nacional de Tecnología Agropecuaria (INTA) durante la última dictadura militar argentina (1976-1983). Buenos Aires. 2010 
investigaciones en función del bienestar conjunto de la comunidad rural, descartando los enfoques fragmentarios y disciplinares, y se proponía que "las tareas científico-técnicas no se divorciaran de la realidad social" (Gárgano. op.cit 2010). En el INTA, un grupo no menor acompañó y gestó proyectos y líneas de investigación, en consonancia con las teorías críticas del modelo desarrollista surgidas en ese momento.

Dos años antes que la Dictadura interrumpa el proceso constitucional, varios técnicos del INTA habían participado en el asesoramiento de las políticas agrarias del gobierno de Cámpora. Entre las políticas y medidas más destacadas de este período presidencial se encuentran: la suspensión de juicios y desalojo de tierras (ley $\mathrm{N}^{\mathrm{o}}$ 20.5618), de defensa forestal (Ley 20.531), la ley de fomento agrario que otorgaba créditos para la compra de tierras y herramientas a los arrendatarios y aparceros (ley. 20.543), la creación y ampliación de funciones de la Junta Nacional de Carnes (JNC) y la Junta Nacional de Granos (JNG), desde donde el Estado comenzó a intervenir en la producción, circulación y comercialización interna y externa de la carne, los granos y sus productos derivados (ley № 20.535/ ley 20.573). (Makler,2006) ${ }^{61}$ Dentro de las colaboraciones más significativas por parte de algunos profesionales del INTA se plasmaron en lo que respecta el uso y tenencia de la tierra, en el Impuesto a la Renta Normal Potencial de la Tierra (IRNPT), promulgada y sancionada en 1974 (Ley. 20.538) y en la redacción del proyecto de "Ley Agraria". El conjunto de estas medidas adoptadas por el gobierno de Cámpora, encontraron resistencias y críticas por parte de las asociaciones patronales del campo, la Sociedad Rural Argentina (SRA), y la Confederación de Asociaciones Rurales de Buenos Aires y La Pampa (CARBAP). La "Ley Agraria” quedó en proyecto, y con el advenimiento de los gobiernos autoritarios las medidas más estructurales aquí descriptas, fueron derogadas y el plantel del INTA que promocionó y participó de la construcción de estos proyectos, fue desmantelado. Con el golpe de Estado del '76, el Instituto fue intervenido militarmente, y comenzó un proceso de persecución y desaparición de los profesionales que postulaban, o estaban implicados en analizar y trabajar desde una mirada estructural de la economía y los problemas sociales. Esta intervención estuvo determinada por los postulados del neoliberalismo, donde se focalizó desde el INTA el trabajo con productores medianos y grandes en las zonas más rentables del país, buscando maximizar la producción de

61 Carlos Makler, Las corporaciones agropecuarias ante la política agraria peronista (1973-1974) Graciano, Gutiérrez en El agro en cuestión. Discursos, Políticas y Corporaciones en la Argentina, 1870-20. Prometeo Libros. Buenos Aires.2006 
granos para la exportación.

"El análisis de los sistemas de tenencia y propiedad de los recursos naturales, los relevamientos del estado de la fuerza de trabajo en el sector, el desequilibrio regional, fueron reemplazados por el estudio de "microproblemas" ligados con la administración rural y el 'comportamiento' empresarial' (supuestamente) necesario para modernizar el agro.” (Gárgano. op.cit. 2010)

Como hemos argumentado en el capítulo anterior, el INTA sufrió a partir de aquí un profundo y sostenido proceso de mercantilización y fragmentación de sus conocimientos y estrategias, abandonando los trabajos y estudios de las distintas problemáticas rurales, para hacer foco en los productores más aptos para el nuevo modelo del paquete tecnológico. Se focalizó el trabajo de generación y extensión de tecnología para los cultivos claves en la zona más "productiva" y "eficiente" del agro argentino, la llamada pampa húmeda (Que comprende Buenos Aires, gran parte de Córdoba, gran parte de Santa Fe,y gran parte de Entre Ríos). Los técnicos de extensión tuvieron que cambiar su destinatario, de la familia rural, pasar a los productores competitivos.

\footnotetext{
"Para la extensión se definió un nuevo papel, la transferencia de tecnología a los grandes productores capitalizados, signado por un discurso que buscó fomentar la "capacidad empresarial" y se alejó del contacto directo con las comunidades rurales y sus problemáticas. El rol del extensionista, que antes era "el médico clínico local, que estaba asentado en cada pueblo", fue redefinido drásticamente. Pasó de ser "el agrónomo de terreno" instalado en la comunidad, a ser el asesor técnico de los grandes terratenientes."(op.cit. Gárgano. 2010)
}

Con el advenimiento de la segunda fase de implementación del neoliberalismo en Argentina, se profundizaron estos elementos, y se atendió desde los servicios de extensión primordialmente a los grandes y medianos productores, fragmentando distintos proyectos e intervenciones hacia distintos sectores rurales.

Algunos autores logran describir al período en términos de "privatización de la extensión" (Alemany, Trujillo), pero si bien entiendo que se estuvo cerca de esa opción Argentina, a diferencia de otros países del planeta, no privatizó los servicios de extensión agraria. La extensión rural continuó en la órbita pública, con una drástica reducción presupuestaria (se cerraron agencias de extensión), y una desvalorización de sus posibilidades 
institucionales. De una función integral, social y productiva, por parte del extensionista para con las comunidades rurales, se fue conformando, con el ingreso de la privatización del saber científico, un perfil tecnocrático capaz de colaborar con grandes emprendimientos productivos.

Para reemplazar estos déficits provocados en la desinversión de las áreas de extensión se recurrió a las tecnologías masivas de comunicación e información, como estrategia fuerte de difusión de paquetes tecnológicos.

\begin{abstract}
Este proceso se ve fortalecido por el desarrollo de la informática y las tecnologías de la información que han determinado que el sector privado comience a interesarse por el mercado de la información transformando la información tecnológica agraria en una mercancía con valor económico. [...] La mercantilización de la información sería el proceso final de modernización de la agricultura, transformada ya en un eslabón integrado y subordinado al complejo agroalimentario. (Alemany, 2008) ${ }^{62}$
\end{abstract}

El enfoque difusionista, que tuvo su interpelación crítica en el Instituto en los '70, volvió a resurgir como dispositivo de transferencia de conocimientos. Este enfoque sufrió revisiones y ajustes para lograr una mayor eficacia, partiendo de la idea que la interacción es necesaria para la efectiva adaptación de tecnología, en tanto nos permite conocer y caracterizar los públicos destinatarios que reciben la información técnica, logrando dirigirles un mensaje que los interpele directamente, según sus necesidades. En este momento los estudios de comunicación fueron atravesados por el enfoque administrativo, que proponía los ejes y conceptos del management y el marketing. Con el avance del desarrollo de tecnologías de información y comunicación, la centralización y supervisión de funciones, promovida durante estos años dentro del INTA, se vio fortalecida.

El INTA comenzó a experimentar a lo largo de este período una creciente tensión y división de sus dos áreas estructurales Investigación y Extensión. Esta fragmentación obedeció a la idea de parcializar la realidad en unidades desconectadas, de estudiar distintos elementos por separado, sin relación entre ellos; de promover una intensa especialización en la investigación y oferta de resultados. En ambas áreas se dio así, hacia adentro este proceso de segmentación.

62 Alemany, Carlos "Volvió la extensión y se armó la discusión" en Cimadevilla, Thornton Grises de la Extensión, la Comunicación y el Desarrollo. Ediciones INTA 2008. 
Los proyectos y postulados institucionales de la comunicación a partir de los $90^{\circ}$

Propongo detenernos en el documento que reunió y organizó los postulados y directrices de la comunicación en el INTA a partir de los años 90, segunda fase de consolidación de políticas neoliberales en Argentina: el Documento de Comunicación Institucional, escrito por el núcleo central de los profesionales y agentes del área de comunicación. En él, se definen y describen las tres áreas funcionales de trabajo de la comunicación institucional, en donde se "producirán los instrumentos mediáticos"63.

“ Área Logística: Prensa institucional y fotografía

Centralización de información

Archivo y publicaciones

Área Producción: Radio

Televisión y Video

Gráfica

Área Creativa: Eventos

Imagen.” (Doc. Inst.- 1997. op.cit)

La comunicación dialógica, no tiene lugar en la programación institucional, en donde todo se orienta desde un enfoque difusionista. En el texto se asocia el quehacer comunicacional en tanto centralizar contenidos, información, para difundirlos a través de distintos medios y soportes. El enfoque instrumental funcionalista de la comunicación nunca abandonó las prácticas y proyectos del INTA, en los '90 se fortaleció con nuevas propuestas. Entre las novedades, surge en estos años, la idea de construir y fortalecer la Imagen, en tanto marca imagen, imagen corporativa, o imagen identidad institucional. Se busca entonces con

63 Brandes, E; Bontempo, M; Cazón, C; Chapay, M; Corneo, J.G; Matusevich, M; Puig, A; Ciencia, C; Barreto, M.L.; Vecchi, J.L. Documento de Comunicación Institucional. Ediciones INTA. Buenos Aires 1997. 
herramientas de marketing y management, "adecuar la imagen institucional a lo que el INTA está llamado a ser." (Doc. Inst.- 1997. op.cit) En dicho documento se operativiza cómo llevar a cabo esta estrategia,

\footnotetext{
“-Diseño, realización y distribución de una red de carteles indicativos de la presencia del INTA en cada ciudad donde exista una unidad. En el cartel dominará la frase EL INTA ESTA, el logo oficial y la identificación y dirección de la unidad.

-Regalos institucionales para compromisos varios.

-Diseño y realización de un set de CARTAS TECNOLOGICAS del INTA con la propuesta básica de que el INTA pone sus cartas sobre la mesa, el INTA no deja nada librado al azar. Las cartas servirán como regalo institucional, campaña educativa y paneles para un stand del INTA"((Doc. Inst.- 1997. op.cit))
}

El enfoque de la imagen institucional, de instalar una identidad positiva del INTA, lógica que se expandió en el neoliberalismo desde el ámbito privado a algunos sectores públicos, sigue vigente en el Instituto. Es necesario recordar que en estos años, la formación de profesionales de comunicación y los estudios de comunicación en Latinoamérica, se vio orientada por un enfoque administrativo, haciendo base en los "comunicadores institucionales y su inserción en la perspectiva de la instrumentalidad de la comunicación como eje del diseño de imagen y del marketing de las corporaciones en Argentina." (Baccin, 2011) ${ }^{64}$

Dentro de las funciones que el documento instituye para el Equipo de Comunicaciones encontramos las de: "Caracterizar las audiencias, fortalecer la imagen institucional, realizar sondeos de opinión y marketing institucional como herramientas para estructurar correctamente los mensajes" (op.cit. 1997). Divide y recorta a la comunicación en "interna” y "externa", asociando en ambas la idea de homogeneizar para comunicar; en la comunicación externa a través de la construcción de "un solo mensaje, emitido por voces múltiples y respetando las peculiaridades de las distintas audiencias" (Doc. Inst.- 1997. op.cit) Para la comunicación interna postula que:

\footnotetext{
"Sirve no solo para transferir información y entendimiento entre las personas y los grupos sino también para homogeneizar el comportamiento del grupo, base para lograr una cooperación continuada. La eficacia de funcionamiento y la subsistencia de cualquier organización dependen de lo bien que actúen sus
}

64 Cristina Baccin, La Comunicación Institucional, UNICEN 2011 
canales de comunicación.”(Doc. Inst.- 1997. op.cit)

El documento institucional reconociendo a la comunicación como un componente fuerte de la extensión y la transferencia de tecnología, describe los objetivos de la institución, entre ellos el de "apuntar al mejoramiento de la competitividad de las empresas en los mercados." En sintonía con la idea de difusión de innovaciones de Rogers, anteriormente analizada, el documento reafirma el objetivo del INTA en tanto promotor y animador del cambio tecnológico.

"La nueva estrategia de desarrollo del país requiere un modelo de generación y transferencia de tecnología público-privado muy dinámico y fuertemente ligado a la demanda, en el que la comunicación se transforma en un componente estratégico en la promoción del cambio y la canalización de la demanda y oferta de tecnología" (Doc. Inst.- 1997. op.cit)

Aparece en el documento que instrumenta la comunicación en el INTA, una referencia exhaustiva y detallada a las "audiencias", que son agrupadas según sus características socioeconómicas diferenciales, y divididas en dos grandes grupos: Internos y Externos. A ambos grupos se le adjudican subdivisiones, creo oportuno transcribir este texto:

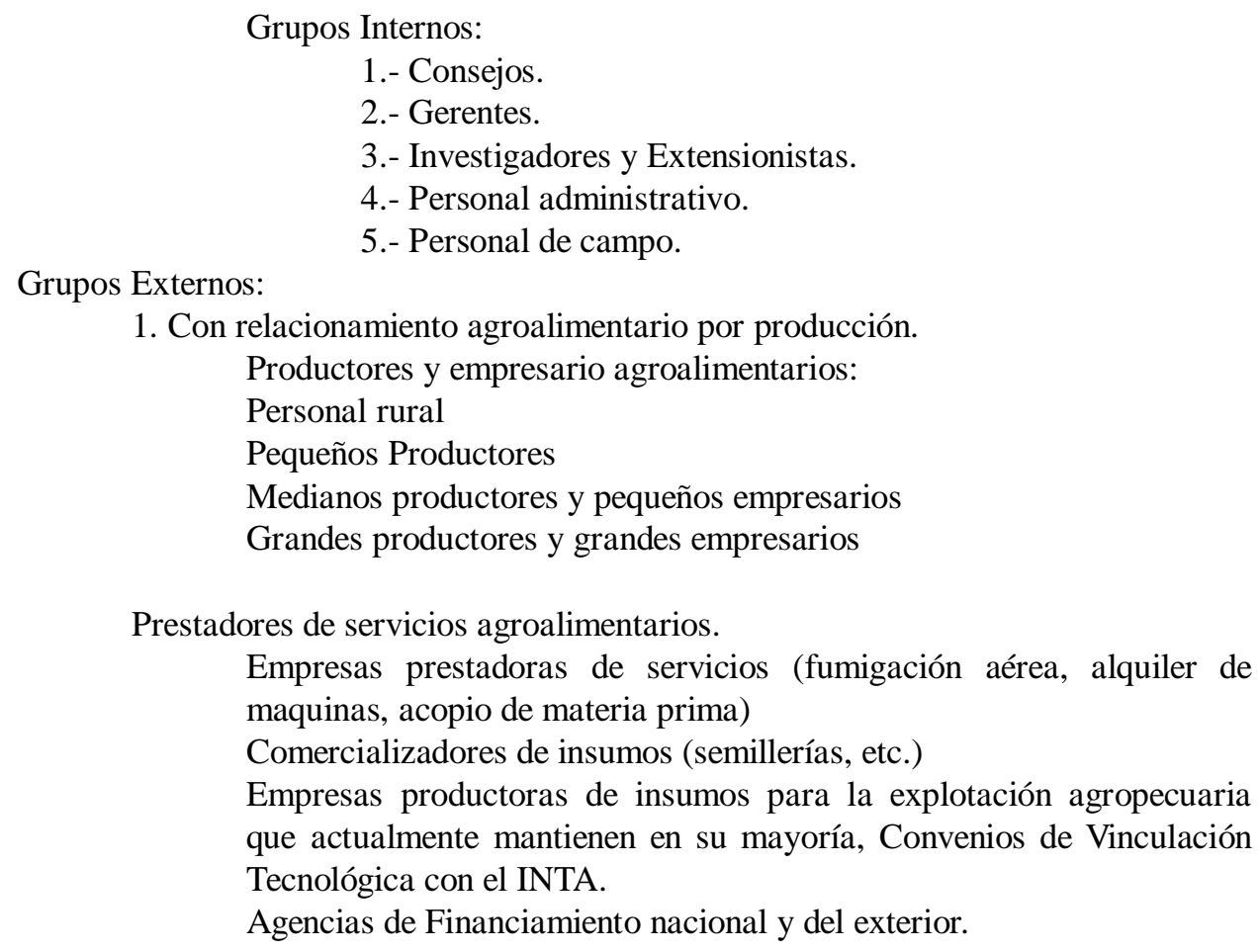

1. Con relacionamiento agroalimentario por producción. Productores y empresario agroalimentarios:

Prestadores de servicios agroalimentarios.

Empresas prestadoras de servicios (fumigación aérea, alquiler de maquinas, acopio de materia prima)

Comercializadores de insumos (semillerías, etc.)

Empresas productoras de insumos para la explotación agropecuaria que actualmente mantienen en su mayoría, Convenios de Vinculación Tecnológica con el INTA.

Agencias de Financiamiento nacional y del exterior. 
2. Con relacionamiento agroalimentario por consumo.

Dentro de este gran grupo incluiremos todos los públicos consumidores, teniendo en cuenta que no todos son iguales ya que algunos, además de su rol social de consumidor, tienen una función social diferenciada (legisladores, maestros, etc.). Por ello, a su vez, los dividimos en varios ítems con el propósito de organizar procesos comunicacionales dirigidos. [...] Son:

Maestros y docentes en general

Familias, como células del consumo

Niños en edad escolar

Estudiantes secundarios y universitarios

Legisladores y funcionarios

Entidades relacionadas con el consumidor.

[...] Cabe destacar que en todos los casos habrá que tener en cuenta los cortes transversales por niveles socioeconómicos.” (Doc. Inst.- 1997. op.cit).

Apelar al "rol social del consumidor", a las familias como células de consumo, es reducir el potencial social, transformador de las personas; al pasar de sujetos en tanto ciudadanos de derechos, a sujetos ciudadanos consumidores. Continuando con esta lógica del economicismo que aparece en esta diferenciación de los sujetos audiencia, podemos relacionar con otro documento de amplia difusión institucional de esos años, donde se describía a la comunicación en tanto "la relación con los clientes internos y externos." 65

\section{Segmentación de estrategias, diferenciación de destinatarios.}

En estos años '90, se experimentó en el INTA, una fragmentación de los conocimientos y disociación de los proyectos en sus dos áreas principales, el Área de Investigación y el Área de Extensión Rural, que sufrieron también esta parcialización hacia adentro. Con respecto al servicio de Extensión, se llevó a cabo una segmentación de los destinatarios, que fueron agrupados por características económicas y abordados por estrategias focalizadas. Si bien en la primera fase de implementación de políticas neoliberales el servicio de Extensión se orientó como asesor técnico de medianos y grandes productores, en los años '90 se institucionaliza esta separación de los actores rurales en relación con su "productividad" (tenencia de tierra, cantidad de hectáreas, herramientas de trabajo, insumos agrícolas, acceso a los mercados,

65 Institucional. Comunicación. Página web www.inta.gov.ar (1995-2006) Ediciones INTA 
capacidad productiva.). Estos distintos grupos conformados por el INTA, en su potencial "económico", recibieron distintos proyectos de intervención, diferentes estrategias de abordaje e interpelación.

"El INTA definió que daría respuestas a las demandas tecnológicas de 5 grandes audiencias institucionales. Ellas eran: los productores minifundistas, la pequeña y mediana empresa rural, la mediana y gran empresa, la agroindustria y los sectores carenciados con insuficiencia alimentaria." 66

Así desplegó en estos años, distintas modalidades de intervención según el destinario. Para el gran productor, y las empresas más importantes en tamaño de producción y comercialización de insumos, podemos a bien decir que fue el Área de Investigación y los Proyectos de Vinculación Tecnológica la gran estrategia de intervención y relación con ellos. Pues en este área se expandió el desarrollo, adaptación y validación de distintos elementos y paquetes tecnológicos para brindar soluciones efectivas y mejoramiento en la productividad a los cultivares principales, y de mejor precio internacional. Fue éste área, priorizada a nivel presupuestario y financiero por parte de las autoridades del Instituto, desde donde se profundizó la estrategia de mercantilización del conocimiento a través de un proceso de transferencia de los saberes técnicos producidos por el INTA, hacia el sector privado, de grandes empresas agrarias, y de capital financiero trasnacional. Este conocimiento se transformó intensamente en estos años, en una mercancía de alto valor.

Como hemos señalado el Área de Extensión fue reducida, y orientó distintos proyectos, que dividieron el mapa socio-rural. Estos proyectos estaban centralizados en la Gerencia de Transferencia y Extensión, donde se los supervisaba y aprobaba. Para el mediano productor se creó el programa Cambio Rural (1993), que reunía a productores de igual o parecida escala productiva y designaba a un técnico que acompañaba el proceso de tecnificación. (Cada 10 productores se designaba un técnico). Para los pequeños productores se creó el Programa Minifundio (1987), dirigido a productores "con escasez de recursos naturales y económicos, parcelas pequeñas en función del núcleo familiar, tenencia precaria de la tierra", y baja remuneración de la mano de obra familiar (INTA, 2007 ${ }^{67}$ ). Cada 40

66 Torres, C y Nocetti, J (1994) en Alemany, carlos. Apuntes para la construcción de los preríodos históricos de la Extensión Rural del INTA. En Thornton, Cimadevilla. La Extensión Rural en Debate. Ediciones INTA. Buenos Aires 2003.

67 INTA, Programa Minifundio. Ediciones INTA. 2007. 
productores se designaba un técnico. Otro programa muy conocido, surgido en los años `90 en articulación con la Secretaría de Desarrollo Social de la Nación es el Prohuerta; dirigido a sectores vulnerables de la población con necesidades básicas insatisfechas. El programa promueve el desarrollo de huertas y pequeñas granjas para el autoconsumo familiar, buscando reducir la indigencia. ${ }^{68}$

Como hemos visto en la estructuración de audiencias que propone el Documento de Comunicación Institucional, el Instituto construye como destinatarios: a grandes empresas, grandes productores, medianos productores, pequeños productores, y personas en extrema pobreza, y les dirige a cada uno un proyecto a su "medida". Este mecanismo fue hegemónico en las políticas públicas desde los años 90 , la política focalizada ${ }^{69}$, a distintos actores de la sociedad, distintas políticas para fortalecerlos. La desigualdad se corre del plano de análisis, se naturaliza. Que haya pobreza, pequeños y grandes productores, no es una realidad posible de articular, de relacionar como devenir de causalidades; pues esta realidad es parcializada, desconectada entre sí para potenciar su productividad. Podemos observar que en este esquema subyace una vez más la teoría modernista, en tanto un desarrollo "madurativo", de pequeños a grandes, sin asumir el porqué de la distancia entre los productores grandes y los productores pequeños. Distancia también profundizada e institucionalizada desde el ámbito público en tanto una diferenciación de políticas, estrategias de intervención y recursos destinados a cada sector.

Es así que en ambos casos, (en los Proyectos de Extensión, como en el Documento de Comunicación) se incurre en un reduccionismo económico, despojando todos los componentes de una sociedad a favor de un relato económico productivista, en perspectiva de entender todo el contexto en la capacidad de acumulación de la renta.

"Una consecuencia del economicismo (aunque no sólo de ello) es la desatención de los aspectos sociales, morales, culturales y políticos de problemas sociales

68 La mayoría de los trabajadores de estos programas fueron contratados, y recién ingresaron a la planta del INTA en el 2007.

69 Se dice que una política es focalizada cuando está dirigida a un grupo específico que es portador de alguna característica determinada. El gasto público se direcciona hacia un subgrupo particular de los ciudadanos de la comunidad; más específicamente, se intenta llegar con el gasto público sólo a una población caracterizada por una situación muy particular. (Esperanza, María. De que políticas hablamos cuando hablamos de políticas universales. Artículo Publicado en blog arte política en 2009.) 
tales como la degradación ambiental, la guerra, el desempleo crónico, la desigualdad en los ingresos, la salud pública, el analfabetismo y el abismo Norte-Sur.," ${ }^{70}$

Los actores del mundo rural, que no entraban dentro de las unidades económicas prósperas del modelo de producción intensiva, fueron dejados de lado y recibieron políticas y proyectos focalizados (Prohuerta). Como hemos visto el paradigma neoliberal impone una reducción de los instrumentos públicos a favor de una apertura de la economía a capitales trasnacionales, destinando a los que no logran entrar en el círculo virtuoso de los beneficios del libre mercado, políticas de complementariedad, de subsidiariedad y de asistencia social. La agricultura "no viable" o el "residuo resistente a la modernización" es un problema que debe ser abordado como una problemática social, no productiva y de crecimiento(Alemany, 2008). ${ }^{71}$

\begin{abstract}
"La agricultura todavía no modernizada en realidad era un emergente del ineluctable proceso de "descampesinización" que tarde o temprano se iba a completar en los países latinoamericanos y, por ese motivo, esta problemática debía ser cada vez más atendida por el componente de "ayuda social" y contención que el Estado necesita impulsar como parte de sus funciones de legitimación política, pero no integrada a la problemática del crecimiento de la agricultura y el desarrollo rural. La evidencia demuestra que el modelo privatista neoliberal se articuló con su componente asistencialista con el objetivo de contener a los "caídos del sistema", expulsados por el ajuste estructural." (Alemany, 2008 op.cit)
\end{abstract}

Mientras que para los actores "dinámicos" de la economía rural, el Instituto transfiere servicios de alta complejidad, paquetes tecnológicos, asesoramiento en gestión empresarial, para los sectores más vulnerados se les proveen capacitación y materiales para armar una huerta orgánica, y pequeñas granjas, para ayudar a reducir la indigencia en esta población. Este proyecto entra en el paradigma de las políticas sociales de "alivio a la pobreza" que promovidas por los organismos internacionales de crédito, como el Banco Interamericano de Desarrollo y Banco Mundial, guiaron el diseño de las políticas en la década del 90.

“Ahora bien, me refiero a ellas como políticas de alivio a la pobreza puesto

70 Bunge, M. Filosofía política. Barcelona, Gedisa

71 Alemany, Carlos "Volvió la extensión y se armó la discusión" en Cimadevilla, Thornton Grises de la Extensión, la Comunicación y el Desarrollo. Ediciones INTA 2008. 
que entiendo que, en los programas de ajuste estructural, las políticas sociales quedan reducidas a acciones que pretenden ayudar a "los pobres" de manera temporal, neutralizando los costos sociales y políticos del ajuste. La naturaleza y el alcance de las medidas se direccionan hacia las consecuencias de la pobreza sin afectar sus causas, a paliar, a aliviar a la pobreza, no a su eliminación." ${ }^{72}$

Quienes quedaron fuera de estas caracterizaciones del Instituto, son los actores organizados de la ruralidad, como los movimientos campesinos y las comunidades aborígenes; que en sí nunca tuvieron una relación activa con el INTA. Los programas de extensión, buscaban formar "grupos" de varios productores de igual capacidad, para llevar adelante la asistencia técnica, aprovechando así, los “escasos" recursos profesionales y técnicos en territorio. Esta concepción de grupos y participación, lejos está de lo planteado a principios de los años `70 en cuanto organización para la transformación de las relaciones injustas.

En estos últimos años hubo escasas y débiles propuestas tanto metodológicas, como teóricas que intentaron pensar a la comunicación rural desde otras bases; pero hasta hoy no han logrado conformarse como otra mirada, frente al enfoque hegemónico de la difusión; y algunas ideas acercándose a esta lógica de divulgación perdieron fuerza y argumento. Para completar una mirada actual sobre cómo se entiende a la comunicación en el INTA, es oportuno mencionar dos instancias estructurales y programáticas actuales de dicha organización: a) en la Gerencia central de Comunicaciones, se describen los perfiles y disciplinas de los profesionales que diseñan e implementan la política comunicacional, reconociendo que con los aportes del periodismo, la lengua, la comunicación social, el diseño gráfico, el marketing y sistemas, estos profesionales forman un equipo que "diseña el mensaje institucional y lo difunde por diferentes medios" (Gerencia de Comunicaciones, 2011 ${ }^{73}$ ) . Entre estos medios y soportes se eligen a los "folletos, carteles, boletines de noticias, sitio web, ediciones INTA, videos, exposiciones, etc.” (op.cit. 2011). b) En el informe de circulación institucional, El Aporte Estratégico/ Plan de Mediano Plazo, elaborado por la Gerencia de Comunicaciones en 2009 , se reconoce como desafío y necesidad para los próximos años, la tarea de "ayudar con metodologías y propuestas para que la comunicación sea un instrumento

72 Gutiérrez, Thais. La construcción transnacional de la idea de políticas de alivio a la pobreza y de sus aplicaciones. En Daniel Mato (coord.), Políticas de economía, ambiente y sociedad en tiempos de globalización. Caracas: Facultad de Ciencias Económicas y Sociales, Universidad Central de Venezuela, pp. 191-209. (2005)

73 Gerencia de Comunicaciones. En Institucional. Ediciones INTA página web. 2011. 
efectivo del proceso de innovación. ${ }^{74 "}$ Con estas postulaciones, y con lo anteriormente argumentado es difícil dar por superado al enfoque difusionista, instrumental de la comunicación, en el INTA. Pues una vez más se vuelve a la idea y propuesta de extender, transferir, divulgar, en donde aparece el Instituto como un único actor emisor que decide, diseña y articula un mensaje para transmitirlo a sus públicos.

Podríamos decir que el INTA ha tenido claramente dos propuestas organizadas de comunicación a lo largo de su trayecto, el difusionismo y la comunicación dialógica; la primera logró actualizarse y sostenerse durante todo el trayecto del INTA; y la otra en cambio, quedó desmantelada cuando comenzaba a articularse como proyecto posible, en el devenir de la implementación autoritaria y hegemónica del neoliberalismo. Reconociendo entonces la impronta difusionista estructurante en los enfoques de comunicación actualmente trabajados en el Instituto, entre ellos: la imagen-marca institucional, y la transferencia de paquetes tecnológicos a públicos diferenciados, podemos reconocer que a lo largo de su historia, tanto en el Área de Extensión, como en las unidades programáticas de Comunicación, el modelo difusionista fue el paradigma instituido del INTA.

Podemos a través de lo expuesto, indicar que el conocimiento, en estos últimos tiempos de desarrollo del neoliberalismo, ha sido potenciado como mercancía y recurso estratégico del sistema de mundialización; que esta reestructuración científico-técnica atravesó todas las dimensiones económicas, sociales, políticas y culturales de la Argentina; que el mundo rural y las unidades académicas y científicas abocadas a él, sufrieron intensos embates del modelo de financiarización programada; que éste es el diagnóstico desde donde hay que partir hacia nuevas forma de construir conocimiento, aunque sea a veces muy pesado de digerir. Este mapeo es punto de referencia ineludible para realizar investigaciones sociales profundas, necesarias, que logrén descifrar desde el reconocimiento de los paradigmas sociales y matrices culturales que imperan en nuestras sociedades, un nuevo horizonte civilizatorio.... para reconciliar el espejo con los rostros humanos.

74 Delgado, Gabriel. Informe Plan Mediano Plazo. Documento Interno. INTA. 2009 
"En términos educativos, esto representa que, son cada vez más, las bases de la mercadotecnia las que gobiernan la orientación y la acción de las instituciones culturales y comunicativas de nuestras naciones y de la región; y no las directrices del desarrollo social y espiritual de nuestras comunidades. Es decir, la modernización neoliberal básicamente ha reducido el proyecto comunicativo y cultural del Estado y de la sociedad a fortalecer y expandir las relaciones de mercado en nuestras comunidades; y no a ampliar y reforzar los procesos culturales más abiertos, democráticos y participativos que durante tanto tiempo han demandado los grandes sectores básicos de nuestros territorios." (Madrid, Javier. La investigación de la comunicación en tiempos neoliberales. de. Razón y Palabra. 1998.)

COMPONENTE II De instrumentos neoliberales, y resignificaciones alternativas.

\section{Neoliberalismo, Participación social y Pobreza}

Propongo enriquecer y profundizar el análisis que venimos desarrollando, sobre políticas públicas y extensión técnica en el modelo neoliberal, desde la deconstrucción de una de las nociones más difundidas en este período. Uno de los conceptos que atraviesa a la gran mayoría de los proyectos de intervención técnica territorial es el de "participación". Y si bien, el término fue y es utilizado de diverso modo en distintos contextos, podemos resaltar que su concepción ligada a transformación, deviene de las teorías y políticas desarrollistas anteriormente analizadas. En estas propuestas la "participación" cumple su rol en tanto 
"facilita" el cambio buscado, hace más eficiente la "adaptación” del desarrollo. Es así que nos encontramos con una definición de la participación entendida como dispositivo, mecanismo para generar consenso en los beneficiarios con respecto a los proyectos, las agencias y los agentes de intervención. Este enfoque instrumental

“...reduce su contenido a aspectos metodológicos y técnicos, donde la participación es algo por conseguirse en los proyectos para hacer posible los fines del mismo. En esta medida, pareciera que la participación de la población es una concesión de los proyectos de desarrollo y no un derecho legítimo de las poblaciones." (León, 2008 ${ }^{75}$ )

Esta conceptualización impulsada por el esquema neoliberal, fue funcional para activar políticas de descentralización y ajuste en Latinoamérica, ya que entre sus influencias y aplicaciones, la "participación" estuvo y permanece asociada a las políticas dirigidas hacia la "pobreza". Y, es este término "pobreza", que fue mutando su concepción mediante la implementación del neoliberalismo, el que guarda una relación implícita con el modelo de la "participación". De aquella idea del desarrollismo, en que una población era pobre pues mantenía una relación ineficiente, un modo de vida arcaico con el mundo, a partir de los años $80^{\prime}$ se comienza a resignificar el contenido de la "pobreza", por parte de los organismos trasnacionales técnicos y de financiación, el Banco Mundial, el Banco Interamericano de Desarrollo, y el Programa para el Desarrollo de Naciones Unidas (PNUD) ${ }^{76}$. Se construye un discurso nuevo que destaca las buenas "aptitudes" y fuertes "capacidades" de los pobres para revertir su situación. Es en esta reinvención de la noción "participación” y "pobreza” donde se construye la idea de que estas poblaciones son las únicas habilitadas para destrabar su propia historia marginal.

"Por ello también, aunque la causa de la pobreza es considerada una consecuencia de incapacidades personales de los propios pobres para competir en el mercado y no el producto de la desigualdad de oportunidades, se comienzan a valorar otras capacidades que aparecen funcionales a una nueva forma autogestionada de regular la pobreza. Aquí la participación de los propios pobres

75 Reflexiones sobre el concepto de participación. Rosario León. En "Bosques, Árboles y Comunidades Rurales". Revista No 25. Cochabamba, Bolivia. 2008.

76 "En esta década se gestó la estrategia de "alivio a la pobreza del Banco Mundial, "la nueva agenda social" del Banco Interamericano de Desarrollo y el Desarrollo Humano del PNU, lo que genéricamente se denomina la estrategia de "lucha contra la pobreza". " Álvarez Leguizamón. 
en su sobrevivencia es un objetivo primordial” (Álvarez, $2008^{77}$ )

Los pobres son nombrados en tanto "trabajadores", “cooperativos entre sî", "honestos", "austeros", "propositivos", "creativos", "resilentes" entre otras aptitudes, que van construyendo la idea de que ellos tienen "resto" para alcanzar por sí mismos el bienestar. Emergen así, además de la "participación social", concepciones nuevas como el "autodesarrollo", "auto-gestión comunitaria"; construcciones semánticas y propuestas políticas que invisibilizan las tramas de poder, esas causas profundas que determinan un estado de vulnerabilidad social; a la vez que promocionan la descentralización de las obligaciones y funciones públicas esenciales de un Estado, desatendiendo así, los legítimos derechos sociales, económicos y culturales de todas las personas. Recordemos que uno de los pilares del modelo neoliberal, y que fue aplicado obedientemente por los gobiernos latinoamericanos en los '90, es la prioridad de reducir el "gasto" social del Estado.

Esta referencia al "auto" proyecto, el "auto" cuidado, la "auto" realización, postula por un lado que los pobres poseen una suma de habilidades para emprender su transformación, pero también deja en claro que son esas competencias, las únicas que pueden lograrlo; pues "auto" en esta conceptualización neoliberal de la participación social de la pobreza, refiere a lo que es propio, a lo que se hace por sí mismos, pero también, y sobre todo a la idea de "solos". La participación social en el neoliberalismo se transforma así, en una estrategia autoresponzabilizante de los sujetos con respecto a su situación de pobreza.

\footnotetext{
"De esto se deduce que todos estos sujetos deben ser asistidos no a través de la Administración y los solícitos expertos que les proporcionaban ayuda y subsidios, sino a través de su propio compromiso con un conjunto de programas destinados a su reconstrucción ética en cuanto activos ciudadanos programas que tratan de equipararlos con las destrezas y aprendizajes de autopromoción, de aconsejarlos para que recuperen su sentido de auto-valor y autoestima, programas destinados a capacitarlos para que puedan asumir su legítimo puesto en cuanto sujetos auto actualizados y exigentes de una democracia liberal "avanzada"” (Rose, 1997)
}

Uno de los documentos emblemáticos que describe y define la cuestión de la

77 Álvarez Leguizamón, Sonia. "El Discurso de la Participación en las políticas sociales de "lucha contra la pobreza", contradicciones y ambivalencias." Sonia Álvarez Edición Consejo de Investigación de la Universidad Nacional de Salta. Argentina. 2008.

78 Rose, Nikolas . "El gobierno en las democracias liberales "avanzadas": del liberalismo al neoliberalismo”. En Archipiélago: Cuadernos Crítica De La Cultura. (1997). 
participación en su enfoque instrumental-desarrollista, es "80 Herramientas para el desarrollo participativo" de Frans Geilfus, que fue editado en el Salvador en 1997. Este libro se realizó desde el aporte de la agencia de financiación internacional y cooperación técnica, GTZ (Deutsche Gesellschaft für Technische Zusammenarbeit - Agencia Alemana de Cooperación Técnica), y el IICA (Instituto Interamericano de Cooperación para la Agricultura) perteneciente a la OEA (Organización de Estados Americanos). El texto-manual produce una exhaustiva descripción de lo que entiende por participación, y es referida principalmente a un contexto rural. Las herramientas y métodos de la "participación" son dirigidas con la intención de que sean apropiadas por los agentes técnicos de los diferentes servicios de extensión en Latinoamérica. Dentro de sus propuestas, presenta una versión del esquema conceptual: "la escalera de la participación ${ }^{79}$ "; en donde detalla una suma de etapas evolutivas que la participación tiene dentro de un "grupo" ${ }^{~} 80$. Esta linealidad acumulativa, y "grados de madurez" por los cuales se promueve avanzar, refieren directamente a la concepción de "etapas del crecimiento" de las teorías del desarrollo que hemos descripto anteriormente en esta tesis. Geilfus parte de este cuadro explicativo, para dar cuenta de cómo es posible "pasar gradualmente, de una pasividad casi completa (ser beneficiario) al control de su propio proceso (ser actor del auto-desarrollo)"

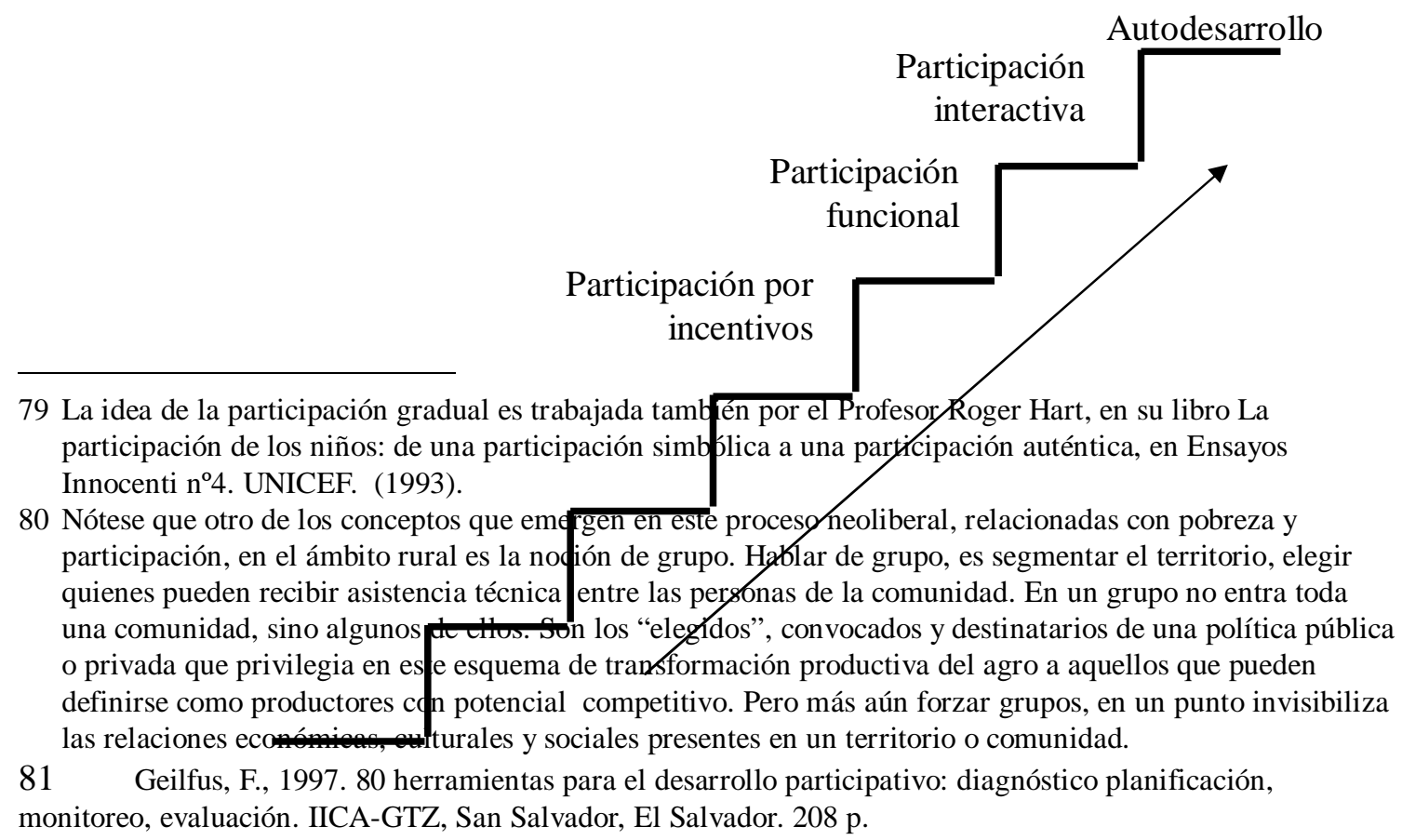




\section{Participación por}

consulta

Suministro de información

Pasividad

La escalera de participación (Frans Geilfus, 1997)

Pasividad: las personas cuando se les informa; no tienen ninguna incidencia en las decisiones y la implementación del proyecto

Suministro de información: las personas participan respondiendo a encuestas; no tiene posibilidad de influir ni siquiera en el uso de que se va a dar a la información

Participación por consulta: las personas son consultadas por agentes externos que escuchan su punto de vista; esto sin tener incidencia sobre las decisiones que se tomarán a raíz de dichas consultas

Participación por incentivos: las personas participan proveyendo principalmente trabajo u otros recursos (tierra para ensayos) a cambio de ciertos incentivos (herramientas, alimentos, etc.); el proyecto requiere su participación, sin embargo las personas no tienen incidencia directa en las decisiones

Participación funcional: las personas participan formando grupos de trabajo para responder a objetivos predeterminados por el proyecto. No tienen incidencia sobre la formulación, pero se los toma en cuenta en el monitoreo y el ajuste de actividades

Participación interactiva: los grupos locales organizados participación en la formulación, implementación y evaluación del proyecto; esto implica procesos de enseñanza y aprendizaje sistemáticos y estructurados, y la toma de control en forma progresiva del proyecto

Auto-desarrollo: los grupos locales organizados toman iniciativas sin esperar intervenciones externas; las intervenciones se hacen en forma de asesoría y como socios. $^{82}$

El crecimiento de la acumulación de más participación, parte desde una lejanía de incidencias y va "subiendo" las distintas etapas hasta alcanzar el auto-desarrollo, donde la

82 Geilfus, F., 1997. 80 herramientas para el desarrollo participativo: diagnóstico planificación, monitoreo, evaluación. IICA-GTZ, San Salvador, El Salvador. 208 p. 
iniciativa es de los grupos locales que "sin esperar intervenciones externas", léase políticas, programas y recursos del Estado, esa población desfavorecida va en busca de su "autodesarrollo". Se plasma nuevamente la máxima de que en la marginalidad, está la matriz de la auto-producción de mejores condiciones de vida. Podemos argumentar que entre las tantas aptitudes "encontradas", asignadas, o promovidas en la pobreza, aparece la capacidad de no aguardar más ayuda externa, la de "confiar" y "encomendarse" a ellos mismos, en tanto dejan de ser pasivos-pacientes, para mutar en agentes activos del cambio.

Retomemos el caso que venimos trabajando, el INTA, para continuar analizando las transformaciones que sufrió la intervención territorial pública a lo largo de estos años de neoliberalismo. Rastreando las concepciones y proyectos impulsados con especial referencia a "la participación", podemos sostener que hay un enfoque instrumental sobre este término que vuelve a regular un servicio de extensión al servicio de un "crecimiento económico" orientado. En el año 1994, Jorge Muani y Luis Bonetto, integrantes de la Unidad de Coordinación de Cambio Rural del Instituto, editaron "La participación como método". Este documento proponía sentar las bases de la extensión de los '90, y fue utilizado para la capacitación de los agentes de extensión de todo el país. En éste, se define como referencia estratégica de la institución, y sostenida desde el trabajo de sus extensionistas, la de "propiciar que los productores sean sujetos de su propia transformación social" (Muani, Bonetto. 1994) ${ }^{83}$. El texto reafirma un reduccionismo económico, antes descripto, que opera en las estrategias neoliberales del Instituto, en tanto focaliza en el cambio productivo, en la empresa agraria, organizando como principales destinatarios a "productores empresariales"; y es así cómo define a los métodos participativos en su capacidad de "posibilitarle al productor conducir y ser protagonista de su propia transformación empresarial." (Muani, Bonetto. 1994) ${ }^{84}$

Más cerca del uso racional de los recursos, del ajuste de los programas estatales, y al servicio de la reducción de la planta profesional de agentes públicos, el programa de extensión Cambio Rural promueve la participación de los destinatarios en grupos de productores, para

83 Muani, J. y Bonetto, L. A. (1994). La participación como método. Programa Cambio Rural. Gerencia de Extensión. INTA. [On line]. (consulta 10-10-2007).

84 Idem. 
recibir la asistencia técnica. ${ }^{85}$ El texto en cuestión, en su simple lógica de definir y asentar bases conceptuales, en su didáctica narrativa, se cuestiona entre varios temas, dos definiciones que vale resaltar:

“Qué es un grupo de productores?

Es un conjunto de productores que interactúan con la ayuda de un profesional de las Ciencias Agropecuarias, con el objetivo común de desarrollar sus empresas y evolucionar como empresarios" (Muani, Bonetto. 1994)

“QQué es la participación?

Participación es el compromiso que asume un individuo o un grupo en una actividad determinada" (Muani, Bonetto. 1994) ${ }^{87}$

Es interesante notar que se permite pensar a "la participación" de un modo pragmático individual, como compromiso con una acción definida. Y si algo que parecía sólido en la concepción de la participación, en cuanto "otros" interactuando, se despeja así la duda, interpelando al sujeto económico que se reúne con otros, tan sólo para recibir la ayuda profesional para su empresa. No se plantea ni planifica en ninguna línea del texto, la interacción entre los miembros del grupo, el potencial organizativo, o algún trabajo mancomunado. El grupo es entendido como un dispositivo, un mecanismo para logra hacer más "eficiente" la intervención; como también se lo diseña como un espacio en donde una suma determinada de individuos, con similares características económicas, reciben información y capacitación que les permite fortalecer, cada uno por sí, el desarrollo de cada emprendimiento.

"La metodología grupal es una herramienta excelente para identificar y resolver problemas. En esencia la actividad del grupo debe posibilitarle al productor identificar los puntos débiles de su empresa; afianzar sus fortalezas y aprovechar las oportunidades que puede visualizar en el entorno. [...] El grupo constituye un soporte importante para

85 La asistencia es desarrollada por un asesor privado (tercerizado) que es a la vez coordinado por un agente permanente del INTA. Cada agente coordinador de Cambio Rural, tiene varios asesores privados con varios grupos. Los primeros dos años de la participación del asesor privado en los grupos, son financiados por el Instituto, al cabo de este tiempo, los productores deben hacer frente a estos costos.

86 Idem.

87 Idem. 
la toma de decisiones empresariales porque sostiene al individuo, le ofrece un ámbito de reflexión sobre las ventajas y desventajas de las alternativas y lo acompañan en la ejecución y mantenimiento de la decisión"(Muani, Bonetto. 1994) ${ }^{88}$

Podemos resumir que para el texto-manual, “La Participación como Método” el acto de "participar" es estar en un grupo individualmente velando cada uno los propios intereses de sus empresas. Esta concepción economicista, e instrumental de la "participación" y el "grupo", como métodos y herramientas, es funcional al objetivo de acelerar el cambio productivo en la ruralidad argentina.

\begin{abstract}
"Los métodos participativos constituyen un camino más seguro para consolidar la transformación económica y social que exige el contexto actual. En otros términos se debe comenzar por transformar la forma de pensar la empresa, de encarar el proceso productivo, de darle significación a la información de mercados, de plantearse nuevas formas empresariales, o áreas de actividad.”(Muani, Bonetto. 1994)
\end{abstract}

Por último, es imposible eludir, cuando se trata de dar cuenta de las concepciones que cruzaron los proyectos de abordaje social, entre ellas la "participación", el texto de Robirosa, Caldarelli y Lapalma, "Turbulencia y Planificación Social Lineamientos metodológicos de gestión de proyectos sociales desde el Estado”, publicado en España en 1989, y reeditado en argentina por $\mathrm{UNICEF}^{89}$ en 1996. En el texto se repite a mi entender el esquema lineal anteriormente descripto, del pasar por distintos "niveles", en cuanto describen los tres modelos de participación:

"Formar parte, en el sentido de pertenecer, ser integrante. (información) Tener parte, en el desempeño de las acciones adaptativas. Los participantes pueden opinar sobre asuntos (opinión)

Tomar parte, entendido como influir a partir de la acción. Los participantes pueden decidir sobre sus propios asuntos. (toma de decisiones)." (Robirosa y otros. 1996) ${ }^{90}$

El texto presenta en gran parte de su trayecto, una ambivalencia en cuanto el potencial

88 Idem.

89 United Nation's International Children's Emergency Fund. En español Fondo Internacional de Emergencia de las Naciones Unidas para la Infancia.

90 Robirosa Mario; Caldarelli Graciela; Lapalma Antonio. Caleti, Sergio. Turbulencia y Planificación Social. UNICEF. Siglo XXI Ediciones. Buenos Aires (1996). 
del concepto estudiado. En algunos párrafos aparece en tanto una simple escalada de la pasividad a la participación, donde la planificación debe apelar a ésta para generar interés, y compromiso de las personas con los proyectos en ejecución; y por otros tramos se lee una mirada política del concepto, cuando logra distinguir la acción individual de la acción colectiva, exponiendo a la participación como proceso de desarrollo de la conciencia crítica y la adquisición del poder. El trabajo postula que la participación social busca promover distintas capacidades culturales y competencias críticas que aportan a conocer la situación actual en relación a sus raíces la transformación social, entre ellas:

\begin{abstract}
"La capacidad reflexiva sobre los hechos, sobre las causas y consecuencias de los problemas de la vida cotidiana; capacidad de crear y recrear no solamente objetos materiales, sino también y fundamentalmente nuevas formas de vida, de convivencia social y de organización social que ayuden a superar los desequilibrios existentes." (Robirosa en Barrientos) ${ }^{91}$
\end{abstract}

Esta resignificación o apertura del término entra en relación con lo trabajado por León en su texto "Reflexiones sobre el concepto de participación" donde desarma el enfoque instrumental de la participación; así como también resalta una otra connotación ética del concepto que "reconoce el derecho legítimo de las poblaciones a planificar y ejecutar sus planes de vida y desarrollo, y recupera la dimensión política de los procesos participativos al introducir el tema del poder en el análisis" ${ }^{92}$.

Podemos argumentar después de lo descripto que si bien "la participación", sufrió en estos años algunas pocas resignificaciones en ciertos contextos con acepciones ampliadas de lo social, en Latinoamérica prevalece instituida en la actualidad, y en la mayoría de los organismos no gubernamentales, trasnacionales, en los institutos y políticas públicas, la esencia de la primera delimitación conceptual (heredada de las teorías modernizadoras del desarrollo), en su reorientación por parte del neoliberalismo. Por eso creo oportuno, que para saltear el cliché que al concepto amenaza, al que nos vemos constantemente expuestos en cada momento

91 Barrientos, Mario “La participación. Algunas precisiones conceptuales”. En La Extensión Rural, Facultad de Ciencias Agrarias. Universidad de Córdoba. 2005

92 Leon, Rosario. Reflexiones sobre el concepto de participación. En "Bosques, Árboles y Comunidades Rurales". Revista No 25. Cochabamba, Bolivia. 2008. 
de nuestra carrera profesional en políticas públicas, es necesario detallar este recorrido de su significación cristalizada; para así construir, o citar una otra orientación de la misma, como también abrir la posibilidad de recurrir a otros términos que refieran más crítica y ampliamente al potencial de los procesos colectivos de transformación social. Será bueno emprender el encuentro y análisis de esas otras nociones que amplían la mirada sobre las instancias de fortalecimiento y democratización de los lazos sociales, pues

"La vida, involucrarse, apostar, formar parte es mucho más que la suma o el conjunto de dimensiones analíticas de la categoría de participación.” (Álvarez, 2008) ${ }^{93}$

"Así es como concebimos el trabajo del agrónomo-educador. Trabajo en el cual se debe buscar, en diálogo con los campesinos, conocer la realidad, para mejor transformarla con ellos."

(Freire, 1973)

\section{Repensar las ciencias sociales, rearmar una comunicación social}

93 Álvarez Leguizamón, Sonia. "El Discurso de la Participación en las políticas sociales de "lucha contra la pobreza”, contradicciones y ambivalencias.” Sonia Álvarez Edición Consejo de Investigación de la Universidad Nacional de Salta. Argentina. 2008. 
Venimos profundizando en este trabajo un análisis exhaustivo y profundo de las propuestas teóricas y los proyectos de intervención territorial y comunicación, instituidas en Latinoamérica, desde la implementación del "camino al desarrollo", propuesto en los años 50. Hemos realizado este trayecto prestando especial atención a la relación de estos procesos de comunicación con las orientaciones político-económicas que operan en ellas (neoliberalismo). También se han problematizado estos análisis, referenciándonos en un Instituto nacional vinculado con la ciencia y la tecnología agraria, como es el INTA, pues entre muchas razones, coincide su creación con la puesta en marcha de las políticas de la Alianza para el Progreso y la modernización productiva del país. Es después de lo elaborado que podemos comenzar a plantear si es posible pensar los procesos de intervención territorial desde otras aproximaciones a la conceptualización y la práctica de la comunicación social, que partan desde otras aspiraciones sociales, y con un enfoque decididamente ampliado sobre lo público.

\footnotetext{
"El terreno del discurso social, el terreno de la cultura, y la comunicación es, consecuentemente, terreno de modelación social, y por ende, terreno de disputas, negociaciones, conflictos y acuerdos del orden del sentido. Reconocer lo que hegemoniza ese campo no impide proponer alternativas, emprender el camino del cuestionamiento." (Mata, María Cristina. Nociones para pensar la comunicación y la cultura masiva. La Crujía. 1990.)
}

Elijo comenzar este trayecto de pensar propuestas, construir prácticas alternativas de abordaje socio-territorial desde la comunicación social, haciendo referencia en primera instancia a la crisis que sufren las ciencias sociales expandida durante el proceso neoliberal en Latinoamérica. Al cuestionar el modelo de ciencia, estaremos describiendo desde un nuevo lugar, el enfoque de intervención territorial que se organiza y orienta alrededor de ella. Es importante plantear y definir la dinámica de la ciencia social, para develar ese nuestro lugar desde donde hablamos y trabajamos: profesionales de las ciencias sociales diseñando, evaluando y ejecutando políticas públicas.

En los últimos años, en nuestra región se profundizó un esquema de investigación y hacer ciencia social que hizo pie en los círculos académicos de formación profesional, tal como en los organismos e instrumentos de planificación social. Como hemos apuntado anteriormente esta ciencia social estuvo orientada desde un reduccionismo económico, desde una promoción de los estudios de mercado y consumo. La matriz neoliberal de las ciencias sociales se piensa al 
servicio, del corrimiento de las obligaciones y funciones de lo público-estatal como ordenador social, de la privatización de la asistencia social, de los estudios que derivan en planes y proyectos focalizados; y de una lógica de segmentación de las investigaciones, donde se descarta las variables de poder, las relaciones macro-micro, y la historicidad de la situación latinoamericana. Se evidencia aún más el distanciamiento y la incapacidad por parte de estas ciencias sociales para interpretar el contexto mediato y estructural de nuestras sociedades latinoamericanas; generando así, una seria dificultad de las mismas, en producir y formular alternativas a favor de la transformación de la realidad. Aclaremos que cuando analizamos el hacer ciencias sociales en este trabajo, estamos haciendo referencia sobre los modos más institucionalizados, y hegemónicos, descartando así los intentos y proyectos que se posicionaron e intentan desde otro paradigma.

Varios autores y pensadores vienen planteando esta debilidad de las ciencias sociales para interpelar los problemas profundos del continente, entre ellos se encuentra la profesora Alcira Argumedo, que en su texto "Crisis de las Ciencias Sociales de la argentina en Crisis", remarca;

"La crisis de las Ciencias Sociales y Humanas, vinculada con sus extremas parcializaciones y el distanciamiento entre la elaboración teórica y los procesos socio-históricos [...]

La endeble formación de los cientistas sociales - salvo los especialistas- en historia de Argentina y América Latina, que lleva a eludir la vigencia del pasado en problemas de actualidad..."94

Atravesando los diversos cuestionamientos y planteos hechos al modo de proceder de los estudios sociales en estos últimos tiempos, se rescata en la mayoría de ellos, una crítica al modo de producción de conocimientos, a la racionalidad que orienta al modelo de ciencia social dominante. Es una racionalidad, que desacredita la territorialidad del pensamiento, la reducción de las experiencias a esquemas conceptuales que recortan sus sentidos y anulan su potencial y riqueza transformadora. Es este "desajuste", el que denuncia Hugo Zemelman, sociólogo y epistemólogo al dar cuenta que

94 Argumedo, Alcira. Crisis de las Ciencias Sociales de la Argentina en Crisis. Prometeo Libros. Buenos Aires 2005. 
"La realidad que enfrentamos, la realidad socio histórica, tiene múltiples significados. No es una realidad clara, inequívoca, con una significación cristalina y a la cual se le pueda abordar sencillamente construyendo teorías o conceptos. No es así por diversas razones, las cuales forman parte del debate que hoy día se da en el ámbito académico sobre el problema que afecta a las ciencias sociales, y que yo resumiría en un concepto: el desajuste, el desfase que existe entre muchos corporas teóricos y la realidad.[...]

Otro valioso aporte a destacar es el que produce el profesor, investigador y militante popular, Boaventura Sousa Santos, quien describe esta dificultad de las ciencias sociales en la medida que legitiman un desperdicio de la experiencia, al invisibilizar, y desacreditar las prácticas alternativas y los movimientos emergentes. Estos postulados son trabajados en sus textos "Renovar la teoría crítica y reinventar la emancipación social”96, y "La Crítica de la razón indolente”97, en donde el autor propone una revisión epistemológica de las ciencias sociales imperantes. Entre otros destacables argumentos, Santos sostiene que las teorías de las ciencias sociales fueron desarrolladas mayoritariamente en unos pocos países del hemisferio norte, y así fueron replicadas en el sur, produciendo una teoría ciega que no refiere a las problemáticas del sur, sino a las necesidades y proyectos del norte. Las ciencias sociales así entendidas colaboran en la reproducción de las desigualdades norte-sur, y se sostienen según Santos con una "racionalidad indolente", en tanto se presenta como única, exclusiva.

Uno de los ejes de esta transformación epistémica, radica en superar, la estructuración de una ciencia desde un objeto de estudio, que en nuestro caso, sería la sociedad. Objeto de estudio que fue promulgado como tal, para ser pasible de análisis exhaustivos, de ser medido con exactitud y a partir de parámetros formales; pues la ciencia cuenta con un instrumental técnico para mapear el objeto de estudio (la sociedad) y estructurar modificaciones en ella. Este aporte técnico se basa en una serie de dispositivos que se presentan como eficaces y lógicos, por demás "neutros" y asépticos de toda opinión, ideología o subjetividad, como sí ella, la ciencia social, pudiese separarse de la propuesta y paradigma político-económico que la gestó y la fueron modelando a medida de su avance. La ciencia se erige como algo incuestionable, como única racionalidad aceptable, borrando sus condicionamientos socio-

95 Zemelman, Hugo, Pensar teórico y pensar epistémico: los retos de las ciencias sociales latinoamericanas, Instituto Pensamiento y Cultura en América Latina, México. 2008.

96 Boaventura de Sousa Santos; "Renovar la teoría crítica y reinventar la emancipación social." Encuentro en Buenos Aires. CLACSO. Buenos Aires, 2006.

97 Santos, Boaventura de Sousa 2003. Crítica a la razón indolente. Contra el desperdicio de la experiencia (Bilbao: Desclee de Brouwer). 
históricos. La ciencia como proyecto del positivismo euro céntrico y expandida para el progreso del capitalismo, fue diseñada y revisada al servicio y medida del sostenimiento y crecimiento de las economías de los actores del mundo moderno.

Pensando, si es posible esto, una transformación de la ciencia social, se busca abandonar la idea de la sociedad, sus instituciones y sus organizaciones, como objetos de estudio; pues en una ciencia disidente, hay que descartar la distancia propuesta entre sujeto conocedor y objeto interrogado. Todos los sujetos somos atravesados por las condiciones socio-históricas, interpelados por los discursos instituidos, convocados por los sentidos sociales en disputa, es imposible pensar una exterioridad o abstracción total, de la dinámica que nos permite ser.

Se descarta, en estas nuevas formulaciones, la posibilidad de pensar en objetos de estudio; y en cambio va emergiendo la idea de la construcción de conocimientos desde una relación sujetos- sujetos, todos investigando sobre la realidad. Las ciencias sociales, y en nuestro espacio, las ciencias de la comunicación social, buscan desde estas revisiones plantear la necesidad de construir relaciones de producción de conocimiento a partir de la relación sujeto-sujeto reflexionando críticamente sobre las problemáticas de la realidad. Se descarta desde aquí la búsqueda de realidades objetivas, de conductas medibles; y se orienta a la apertura de posibles horizontes de sentido para nuestras sociedades Es aquí donde nos avocamos no ya a la búsqueda de realidades objetivas, sino a la apertura de "horizontes posibles de sentido para nuestras sociedades que poseen la potencia de configurar prácticas" (Salazar, 2009).

Una comunicación social alternativa, ofrece el diálogo como espacio privilegiado de la tensión, relación e interacción "sujeto-sujeto", para compartir y cuestionar desde las experiencias subjetivas, los sentidos que le damos a las prácticas sociales.

\footnotetext{
"Ver al otro como objeto de investigación, supone un intento denegado de dominación en el que se deja de ver el régimen de afecciones recíprocas que caracteriza el intercambio con quienes participan en nuestras investigaciones respondiendo a nuestras interrogantes, es decir, se olvida que reaccionamos frente al otro desde nuestra propia subjetividad, que entramos en una relación en donde cada movimiento forma parte de una compleja dinámica de intercambios y estrategias que desbordan al objeto de investigación, tales como la seducción, el control, la resistencia, el rechazo, la comprensión, la
} 
acogida, etc." 98

El pedagogo Paulo Freire, nos invita a comprender al conocimiento como una creación que sólo puede darse desde una relación entre sujetos, pues entiende que no hay pensamiento aislado, como tampoco existe hombre aislado, y postula que hay acción cognitiva sólo si hay interacción comunicativa.

"Por lo tanto, la función gnoseológica no puede quedar reducida a simples relaciones de sujeto cognoscente, con el objeto cognoscible. Sin la relación comunicativa entre sujetos cognoscentes, en torno a un objeto cognoscible, desaparecería el acto cognitivo". 99

Sostiene que la educación como práctica de la libertad, es sobre todo y antes que todo, "una situación verdaderamente gnoseológica", donde el educador como el educando desarrollan una búsqueda conjunta del conocimiento. Reconstruyendo el modelo de intervenciones técnicas agrarias, Freire postula que "la educación es comunicación, es diálogo, en la medida en que no es la transferencia del saber, sino un encuentro de sujetos interlocutores, que buscan la significación de los significados" (Freire, 1973) En esta mirada, el acto de conocer en tanto sujetos coparticipando en la producción de saberes sobre la realidad, tiene como principal finalidad ineludible la transformación de ésta.

\section{Comunicación e Intervención}

Pensar a la comunicación más allá del conjunto de dispositivos tecnológicos de persuasión, del enfoque instrumental, es entenderla como una dimensión constitutiva de lo social, es apreciarla como práctica social conformada por relaciones intersubjetivas, es habilitar a pensar "lo comunicacional" existente en todos los procesos sociales, en su dinámica cultural, política, organizacional, comunitaria. Dimensión cultural en tanto los procesos comunicacionales auspician constantemente la producción de sentidos, e interactúan entre sí en una disputa simbólica, muchas veces desigual; dimensión política entendiendo que toda

98 Salazar, C. (2009). El sujeto no es un objeto de investigación. Versión corregida y ampliada del trabajo presentado en las XV Jornadas de investigación. Cuarto encuentro de investigadores en Psicología 99 Freire, Paulo. ¿Extensión o Comunicación? La concientización del medio rural. Siglo XXI Editores. 1973. 
propuesta del hacer comunicacional, sin importar su escala de llegada, produce o reproduce un modelo de circulación de poder; Organizacional y comunitaria, porque abandona al sujeto como individuo en sí mismo, para convocar a aquellos actores colectivos que resisten los embates neoliberales, y trascienden sus acciones a la comunidad.

\footnotetext{
"Pensar los procesos de comunicación desde ahí, desde la cultura significa dejar de pensarlos desde las disciplinas y desde los medios. Significa romper con la seguridad que proporcionaba la reducción de la problemática de comunicación a las de tecnologías." (Martín Barbero, 1987) ${ }^{100}$
}

Podemos adscribir a una perspectiva sociocultural emergente de la investigación en comunicación en Latinoamérica. En esta matriz, Raúl Fuentes Navarro propone partir de la cotidianeidad, de la acción comunicativa y constitutiva del ser en la vida social, que cimiente las bases para la superación de la concepción predominante instrumental. (Fuentes Navarro, $1999^{101}$ )

\footnotetext{
"Son los procesos comunicacionales que ocurren en momentos y lugares en que se configuran, producen e intercambian sentidos, se conforman modos de percepción, se reflexionan las experiencias y se generan estrategias" ( Rincón, 2005. $)^{102}$
}

En este trabajo hemos analizado críticamente el andamiaje socio-histórico de los dispositivos de la modernización, recorriendo sus prácticas y discursos hegemónicos en los últimos 60 años en Latinoamérica. Estos instrumentos técnicos: extensión, difusión, innovación, desarrollo, participación, pueden agruparse bajo la noción de intervención social. La "funcionalidad" operativa del término intervención social, institucionalizado en el proyecto de la modernidad, se instauró como el mecanismo para corregir los problemas y desvíos sociales de lo que no entraba en la lógica de la racionalidad imperante. Refiere a un conjunto de discursos y prácticas, ejecutadas por "agentes técnicos" para introducir modificaciones en

100 Martín Barbero, Jesús; De los medios a las mediaciones, de. G. Gilli, Barcelona, 1987.

101 Fuentes Navarro, Raúl. La investigación de la comunicación en América Latina: condiciones y perspectivas para el siglo XXI. Diálogos de la Comunicación N 56, FELAFACS, Lima, 1999.

102 Rincón García, Luis Antonio. Un acercamiento a los procesos comunicacionales en la comunidad indígena tzotzil de Zinacantán, en Zona Altos de Chiapas, México. Tesis de Maestría. Facultad de Periodismo y Comunicación Social. Maestría en Planificación y Gestión de Procesos Comunicacionales. 2005 . 
las situaciones que entienden como problemáticas. La intervención social como propuesta de abordaje territorial, implica un núcleo exterior que decide actuar en un espacio socialmente delimitado, para cambiar aquello que entiende como "atraso" y amenaza al desarrollo y el crecimiento económico. En esta concepción del término se prefigura una relación entre interventores e intervenidos, donde los primeros tienen capacidad y margen de acción, y los segundos son receptores de los beneficios de su modelación social.

Hay otras nociones para pensar los procesos de abordaje social, que aparentan partir de una visión heterogénea y distinta del que propone la modernidad, aunque también son en esencia funcionales a este paradigma dominante, mediación social, ingeniería social, asistencia social. La conceptualización de intervención sigue vigente en los ámbitos académicos, y en los organismos e instituciones de políticas públicas; y si bien a lo largo de estos años se intentó más de una vez su resignificación, el término continúa ligado a un modelo asimétrico. Propongo entonces ir superando el esquema de interacción desigual, dirigista y vertical entre agentes y asistidos que postula la intervención social, para adscribir y desarrollar otras posibilidades de acercamiento a los procesos sociales, donde emerja una relación más comprometida y decididamente democrática para con las causas, miradas y decisiones populares. La comunicación social puede pensarse como una alternativa desde el trabajo comunitario.

\section{Planificación y Comunicación}

La planificación como concepto de estrategias para reordenar y gobernar la sociedad surgió con la modernidad occidental europea; y en Latinoamérica fue expandida y reinventada desde la implementación de la Alianza para el Progreso, y estuvo fundamentalmente difundida desde la CEPAL (Comisión Económica para América Latina, perteneciente a las Naciones Unidas), en tanto el dispositivo técnico para ordenar y llevar a cabo, de manera direccionada la transformación productiva del mundo subdesarrollado. Es Arturo Escobar, antropólogo colombiano, quien comienza a revisar críticamente al instrumento "planificación" que el 
"desarrollo" exige, argumentando que ninguna otra noción ha resultado tan dañina para Latinoamérica, y a la vez tan poco revisada y cuestionada (Escobar, 1992). ${ }^{103}$ El subdesarrollo, o el tercer mundo, es moldeado mediante la planificación para transformarla en una sociedad moderna.

"Se confiaba en que, casi que por fiat tecnológico y económico y gracias a algo llamado planificación, de la noche a la mañana milenarias y complejas culturas se convirtieran en clones de los racionales occidentales de los países considerados económicamente avanzados." (Escobar, 2007) ${ }^{104}$

Este término no se diferencia mucho de las funcionalidades y operaciones de los otros instrumentos, como la comunicación rural, la intervención, que hemos desarrollado en esta tesis. Desde esta metodología se implantó la fuerte imposición de organizar todas las dimensiones sociales al servicio del "plan de crecimiento económico", que todos los países debían adscribir para recibir ayuda financiera de los organismos multilaterales de crédito, "por lo que la planificación era un prerrequisito para obtener los recursos prometidos que iban a garantizar el "desarrollo"”. (Llaguno Thomas, 2010) ${ }^{105}$

En los años sesenta se abren una importante cantidad de oficinas técnicas de planificación nacional en Latinoamérica, aparecen un sin número de publicaciones sobre el tema, y se promueve la formación de un vasto grupo de técnicos en planificación y programación, muchos de ellos pertenecientes a las ciencias sociales, que pasaron a ser "funcionarios de planificación".

"El desarrollo debe cumplirse con la contribución de las ciencias sociales (teorías, metodologías, técnicas, más y mejor conocimiento de las realidades específicas, formulación de alternativas realmente racionales y viables); por el Estado; por el advenimiento o la consolidación de un orden democrático y por el uso de la planificación" (Kaplan, 1991$)^{106}$

La planificación se presenta desde el cálculo racional y su capacidad de previsión, como

103 Escobar, Arturo. La invención del Tercer Mundo. Construcción y deconstrucción del desarrollo. Editorial Norma. 1996.

104 Idem.

105 Thomas Llaguno, Esteban "Prolegómenos de colonialidad en América Latina. La planificación y la Alianza para el Progreso (1961-1965)” Ed. Rebelión.org 2010.

106 Kaplan Mario, La Planificación Latinoamericana: Concepciones y experiencias. Boletín Mexicano de Derecho Comparado, vol. XXIV, num. sep - dic. 1991. 
una técnica de control social, capaz de reorganizar las actividades económicas y así la transformación productiva. Pues el organismo u Instituto que ejerce planificación en este contexto, es aquel que puede medir, evaluar y así administrar la realidad. Con respecto a esto, Escobar se pregunta si es posible "administrar" la realidad.

Los conceptos de planificación y administración (gestión, gerencia) implican la creencia de que el cambio social puede impulsarse y dirigirse, producirse a voluntad. Los expertos en desarrollo siempre han acariciado la idea de que los países pobres pueden moverse con mayor o menor celeridad a lo largo de la senda del progreso mediante la planeación. (Escobar, 1996) ${ }^{107}$

La planificación así entendida, reproduce un modelo centralizado y vertical de toma de decisiones de los agentes del desarrollo hacia los subdesarrollados; también promueve la concepción lineal de la historia en tanto progreso, en tanto escalones de madurez. Y aunque algunas planeaciones se orientaron a una cuestión participativa, en la mayoría de ellas se ejecutó esta modalidad para lograr consenso en las políticas.

Si bien, el término sufrió algunas críticas y fue releído en diferentes contextos, en Latinoamérica no pudo escapar de su orientación de racionalización de la vida social, determinación de las "buenas” prácticas y saberes, organización económica, y direccionalidad única, euro céntrica y acumulativa hacia el bienestar. Esta perspectiva, continuó desprestigiando aquellos "otros" saberes; esos diversos modos de reproducción de la vida y de organización alternativa social presentes en Latinoamérica, que pasaron a ser arcaicos, irracionales e imprevisibles.

Se nos abre aquí, una cuestión clave para la presente tesis, o intentamos resignificar la planificación como instancia para el trabajo comunitario, o abandonamos este trayecto para ir en búsqueda de otras propuestas conceptuales. A diferencia de los otros dispositivos que utilizó el desarrollismo en Latinoamérica, propongo intentar, después de descifrado su proposición en el contexto socio-histórico de su origen y desarrollo, reconstruir un otro paradigma de la planificación desde una mirada comunicacional. Para esto creo oportuno construir y agrupar algunos horizontes deseables, propuestas para ir orientando nuestra

107 Escobar, Arturo. La invención del Tercer Mundo. Construcción y deconstrucción del desarrollo. Editorial Norma. 1996. 
práctica de los trabajadores de la comunicación comunitaria en el ámbito de la política pública.

En primer lugar, repensar una planificación desde las prácticas comunicacionales, es plantearla como un espacio de socialización, un encuentro donde se fomenta la circulación de las distintas voces, opiniones y decisiones, sobre la realidad en la cual se desenvuelve la comunidad, y así poder ampliar esta mirada. También es válido proponer, como desarrollaremos después, que todo proyecto que se oriente a una concepción social de los procesos de comunicación conlleva dos componentes ineludibles: el educativo y el político. (Cardoso, 2000 ${ }^{108}$ )

Es a partir de la desfragmentación de la única voz del que dirige un proceso de planificación, del resurgimiento de lo polifónico como horizonte, la multiplicidad de enunciadores, donde lo comunicacional, en su instancia democratizadora desata un proceso que promueve la de-construcción y construcción de nuevos sentidos, que podrán derivarnos a nuevas realidades. En el plano de lo compartido desde la mirada comunicacional, la propuesta de diálogo y la toma de la palabra, se hacen iniciáticas para abordar de modo colectivo aquellos problemas comunes. La planificación en este sentido del fomentar, multiplicar y ampliar espacios de reflexión conjunta, reúne esfuerzos para validar la voz propia de los actores involucrados en el proceso. La toma de la palabra, como acto inaugural de una comunicación transformadora que habilita, el "yo me nombro, yo nombro (descifro) al mundo, yo decido", para entrar desde ahí en relación y tensión con aquello "que me nombra, que me cierra una mirada del mundo, y lo(s) que decide(n) por mi”. Voz propia, "yo", que se acerca desde una propuesta de comunicación a sumarse con otros "yo", conformando un espacio social propio en un "nosotros", como instancia de aquello común que contiene y construye una identidad, un otro modo de habitar el mundo. Es entonces el proceso dialógico el que va fortaleciendo esa voz colectiva, en tanto "nosotros nos nombramos, nosotros nombramos al mundo, nosotros empezamos a decidir", para comenzar a transformar las relaciones de poder, de sentidos "incuestionables". Voz, palabra y decisión, espacios íntimos de una genuina comunicación para la transformación.

Hemos asistido en los últimos años a distintos enfoques de planificación, que si bien disímiles en origen y diversos en sus propuestas políticas, mantienen la idea de la planificación

108 Cardoso, Nelson. La Comunicación Comunitaria. Bibliografía Modulo 1. Taller Cuatrimestral de Comunicación Comunitaria. 2000. 
como conjunto de momentos que buscan cerrar, decidir un futuro, y ordenar pasos para traccionar la realidad a ese horizonte cristalizado. Y si bien, el futuro es parte de cualquier proceso de transformación, cierta obstinación con los pasos, "lo ordenado" y sus órdenes, ciegan gran parte del proceso, quitando creatividad y posibilidades de enriquecimiento continuo. Cuestiono muchos de estos esquemas pues no concibo cómo lograr fuerza-energía colectiva alentar la creatividad, cuando el proceso está sellado y hecho en consignas.

Planificar desde la concepción que venimos armando, tiene que ver más con abrir espacios, desatar procesos cooperativos, y promover la imaginación popular, antes que ordenar momentos matemáticos y lógicos, homogenizar objetivos rígidos y medir resultados. Una planificación des-planificada, desandada desde un proceso continuo de "acción - reflexión", donde amplía los márgenes de reinterpretación, reorientación, para habilitar un proceso más espontáneo, que respete el aprendizaje colectivo, y las temporalidades del compartir; pues el universo de las prácticas y sentidos de lo colectivo, es un proceso vivo, de constantes reinvenciones.

"Es preciso que el educando vaya descubriendo la relación dinámica, fuerte, viva, entre palabra y acción, entre palabra-acción-reflexión. [...] Obrar, hablar, conocer, estarían juntos." (Freire, 1985)

Entonces, antes que la conformación de objetivos, construcción de indicadores y marco-lógicos, es oportuno habilitar el ingenio de las personas, dar lo mejor de nuestra creatividad social, para ampliar espacios de comunicación, del decir, del nombrar, del preguntarse.

Podemos así, adscribir a la propuesta de Freire, que dando cuenta de los métodos hegemónicos de educación formal, encuentra una constante "castración" de la curiosidad, donde se debilita y suprime la posibilidad de cuestionar, indagar. Propone para esta dificultad, caminar hacia una pedagogía de la pregunta, que habilite una exploración.

\footnotetext{
“Insisto en que la educación, en general, es una educación de respuestas, en
}

109 Freire, Paulo. "Hacia una pedagogía de la pregunta. Conversaciones con Antonio Faúndez". Ediciones La Aurora. Suiza. 1985. 
lugar de ser una educación de preguntas. Una educación de preguntas es la única educación creativa y apta para estimular la capacidad humana de asombrarse, de responder a su asombro y resolver sus verdaderos problemas esenciales, existenciales, y el propio conocimiento." (Freire, $1985^{110}$ )

La pregunta en un ámbito de comunicación entre pares, habilita la reflexión crítica de la realidad, la indagación de las causas que determinan la situación actual local, conformándose así en un proceso educativo y político. Educativo pues al confeccionar desde las propuestas y miradas de un conjunto de personas, el aprendizaje colectivo sobre la realidad se enriquece y se hace más intenso. Político en tanto busca, aún cuando parta de situaciones muy pequeñas, comenzar a quebrar y tensionar las relaciones materiales, de poder y culturales que conllevan a su situación de pobreza. Esta experiencia subjetiva y colectiva de comunicación se inaugura desde una mirada detenida sobre los problemas comunitarios, pasa a una reflexión en búsqueda de las causas primeras de esa situación, para después con esta construcción crítica, poder accionar desde ese aquí y ahora de los involucrados, nuevos trayectos, movilizaciones, medidas de fuerza.

En esta concepción que adherimos e impulsamos desde esta tesis, el profesional de la ciencia de la comunicación, ya no es una externalidad al proceso, sino que trae a la mesa de trabajo su experiencia subjetiva, que aunque nutrida y certificada en otros ámbitos, promueve relacionarse con las experiencias y saberes de los actores en donde se trabaja, para poder nutrir trayectos compartidos. Compromiso social de los trabajadores de las ciencias sociales en las comunidades, para poner a disposición sus posibilidades y aptitudes reflexivas al servicio del fortalecimiento de los lazos sociales y comunitarios, los cuales lo incluyen. Es entonces ineludible mencionar esta vocación militante del que aspira caminar hacia una ciencia social alternativa, decisión que puede nacer de entender, conocer y resignarse a mantener las estructuras y dispositivos que operan en el sostenimiento de las desigualdades latinoamericanas.

110 Freire, Paulo. "Hacia una pedagogía de la pregunta. Conversaciones con Antonio Faúndez". Ediciones La Aurora. Suiza. 1985. 
Llegado a este punto, podemos coincidir que una propuesta de una comunicación ampliada promotora de procesos comunitarios, se da en tanto los sujetos del territorio y el trabajador comunitario conforman un equipo de trabajo, en donde son hacedores de reflexiones, de debates, que impulsan un proceso colectivo de elaboración de conocimiento crítico, que les permite situarse y accionar desde otro lugar frente a las problemáticas comunes. Pero no "accionar" en el sentido de auto-responsabilidad de los actores sociales en hacerse cargo de su vulnerabilidad social, como vimos en el modelo de autogestión y participación del neoliberalismo, donde se invisibilizan las causas estructurales de la pobreza; sino más bien, en sintonía con una comunicación disidente que genere y potencie espacios y proyectos de edificación cooperativa de una trama de sentido socio-cultural, que dispute educativa y políticamente saberes, espacios de poder, de decisión, y proyectos.

Retomando, por último los aportes del profesor Sousa Santos, en su recorrido crítico sobre las ciencias sociales modernas y sus consecuencias planetarias, en donde alienta a producir un pensamiento alternativo de las alternativas sociales que emergen; y para este trayecto de acercarse, acompañar y fortalecer estos procesos insurgentes, que asoman por fuera del "desarrollo", diseña algunas pistas metodológicas para facilitar este encuentro. Desarrolla así, dos inicativas como posibilidad de emprender una ciencia disidente, para emprender un nuevo conocimiento, y poder dialogar con lo que quedó al margen de la modernidad, aquellas culturas, organizaciones y movimientos que resistieron, se tensionaron, y quedaron por fuera del mundo único del desarrollo; estas son: la Sociología de las Ausencias y la Sociología de las Emergencias. Ambas metodologías se complementan, en tanto la primera se orienta a visibilizar y adentrarse a aquello que la modernidad no iluminó y descartó, mientras que la segunda promueve fortalecer y proyectar a las nuevas experiencias que están surgiendo en el contexto neoliberal para que crezcan.

\footnotetext{
"La sociología de las Ausencias es un procedimiento transgresivo, una sociología insurgente para intentar mostrar que lo que no existe es producido activamente como no existente, como una alternativa no creíble, como una alternativa descartable, invisible a la realidad hegemónica del mundo." (pág. 23)
}

“La sociología de las Emergencias produce experiencias posibles, que no están 
dadas porque no existen alternativas para ello, pero son posibles y ya existen como emergencia." (pág. 31)

Es así que una planificación planteada desde una comunicación genuina y con horizontes políticos de transformación, rescata estos dos movimientos epistémicos, en tanto hacer una sociología de las ausencias, es encontrar, reconocer y valorar esa cantidad de perspectivas de habitar el mundo que no entran en el paquete del capitalismo; como a la vez emprender una sociología de las emergencias, es involucrarse en el entramado social de las nuevas realidades por llegar. 
COMPONENTE III

Formosa, postales en proceso.

A orillas del agronegocio, donde la vida...

Venimos desarrollando críticamente los postulados ideológicos y socio-históricos que sostuvieron y sostienen el sistema de extensión, y su propuesta de comunicación rural; ambas como parte de las políticas públicas agrarias en Argentina. Este desarrollo lo hemos enriquecido deteniéndonos en el Instituto público rural, INTA, que es el de mayor magnitud y considerado el más importante en Latinoamérica en cuestiones de investigación y extensión agraria.

También hemos desandado los instrumentos del desarrollismo y su propuesta en el neoliberalismo, pudiendo así descartar y resignificar entre estos conceptos, para pensar un abordaje comunitario desde otros paradigmas sociales. Es momento de intentar ver más de cerca, cómo articulan estas conceptualizaciones y propuestas institucionalizadas y emergentes desde la unidad INTA que ocupo como trabajador (en INTA Formosa).

Este apartado guarda entre otras, dos intenciones; primero poder dar cuenta de algunos procesos sociales comunitarios que escapan a la lógica empresarial del agronegocio en Formosa y a su vez la tensionan; descifrando cómo estos sujetos no entran dentro de los destinatarios de las políticas del INTA. Este recorrido y acercamiento a los procesos sociales y prácticas comunitarias parten desde un enfoque en construcción de lo comunicacional-social del trabajo en territorio rural.

Propongo por último, al final de este apartado, y a partir de la sistematización de los encuentros con las experiencias sociales, poder construir unas líneas de acción a promocionar y llevar a cabo a partir del proceso de comunicación de la presente tesis, para instaurar una relación entre el INTA Formosa, y los actores colectivos del territorio.

Para llevar a cabo un trabajo de cercanías es necesario dar cuenta del contexto mediato de la situación territorial en la que se encuentra nuestra búsqueda. Es por eso que contextualizaremos desde Formosa. 


\section{Formosa}

Durante los años 2006 hasta el 2009 tuve la posibilidad de trabajar en la provincia de Formosa, en el noroeste de la república argentina, en el INTA. La provincia de Formosa, linda con la provincia de Salta y Chaco, a la vez que gran parte de su frontera es el límite entre la Argentina y el Paraguay. Por el norte de la provincia pasa el Trópico de Capricornio, ubicándola en el ecosistema sub-tropical. Dos ríos delimitan sus coordenadas geográficas en el norte, el río Pilcomayo y en el sur, el Río Bermejo. Comprendida dentro de una de las regiones geográficas más grandes del cono sur, el Gran $\mathrm{Chaco}^{111}$, Formosa es considerada como parte predominante del Chaco Central, ubicado entre el Chaco Boreal y el Chaco Austral. La región del Chaco se extiende por parte de los actuales territorios del norte de Argentina, Bolivia, Brasil, Paraguay, y entre los ríos Paraguay y Paraná y el altiplano andino. ${ }^{112}$ El Gran Chaco a diferencia de la zona pampeana del centro del país se caracteriza por la presencia de importantes bosques, selvas y parques, con predominio de especies de madera dura con suelos con elevadas concentraciones de sal. ${ }^{113}$ Es una de las regiones con mayor biodiversidad en el mundo (REDAF, 2009 ${ }^{114}$ ). En cuanto a las temperaturas en gran parte de la provincia de Formosa, en los meses de verano puede ascender a 55 grados.

Dividida en departamentos, la provincia de Formosa cuenta según estimaciones públicas con 527.895 habitantes (INDEC, 2010) ${ }^{115}$. Sus 9 departamentos son Bermejo, Formosa, Laishi, Matacos, Patiño, Pilagás, Pilcomayo, Pirané, Ramón Lista. A la vez dentro de estos departamentos se ubican alrededor de 30 municipios, 10 comisiones de fomento y 18 juntas vecinales provinciales.

\footnotetext{
111 Chaco, del quechua chaku, zona de cacería.

112 "Gran Chaco" en Wikipedia. 2012.

113 Idem.

114 Informe Ejecutivo "Conflictos de Tierra y Medioambiente en la región del Chaco-Argentino" Red Agroforestal Chaco Argentina (REDAF). 2009.

115 Instituto Nacional de Estadísticas y Censo. 2010.
} 


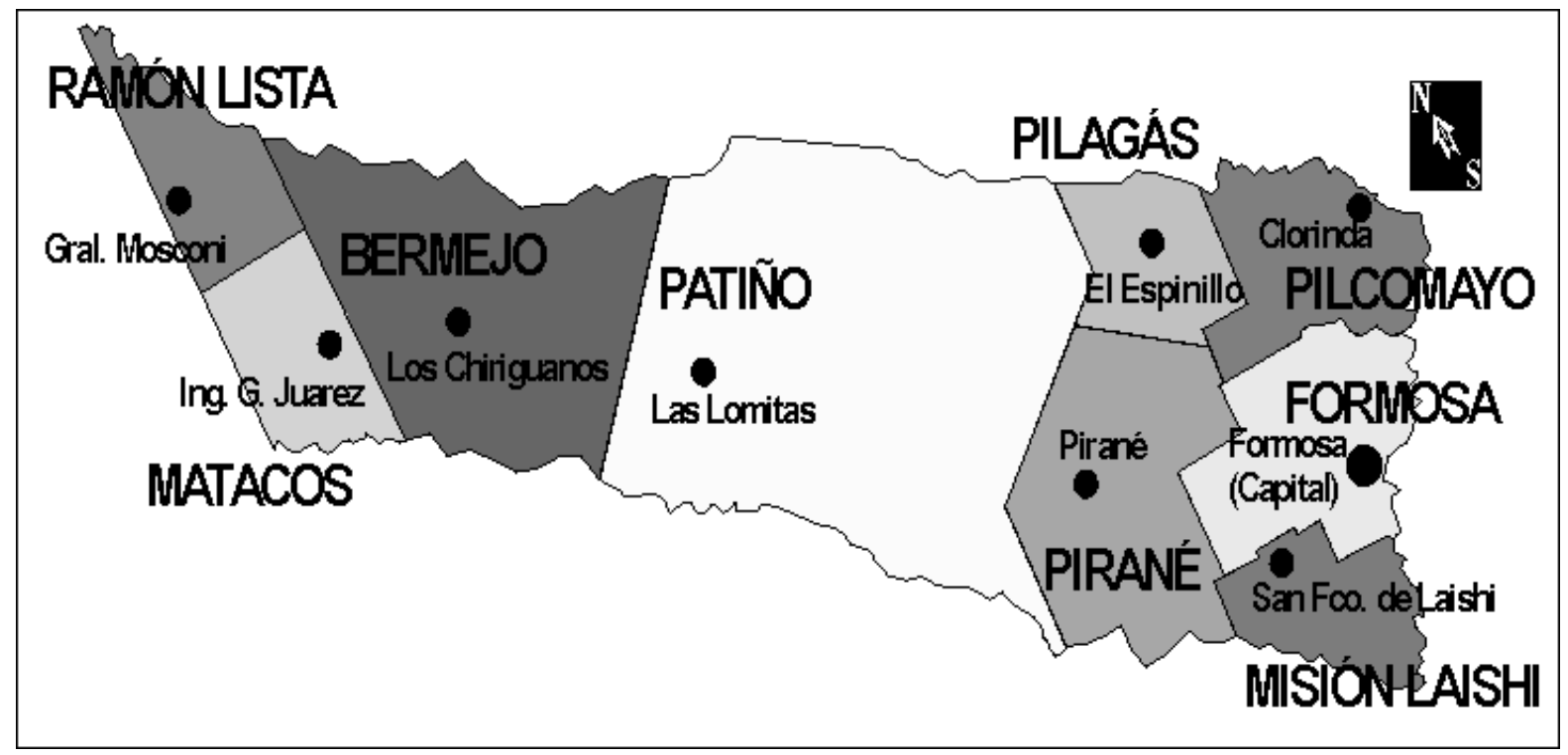

Para caracterizar la provincia en tanto su clima, suelos y producciones agropecuarias actuales, podríamos decir que el oeste presenta un clima agresivamente árido, de pocas lluvias y gran sequía, donde actualmente se lleva una actividad económica precaria, mayormente dominada por ganado caprino y bovino. Las temperaturas varían mucho durante el día y la noche, esta es la zona más pobre de la provincia. En el centro encontramos un clima menos hostil que en el oeste, donde se suceden mayores precipitaciones, la actividad principal es la agricultura de algodón, trigo, soja y hortalizas; también posee emprendimientos ganaderos. En el Este, encontramos la mayor densidad poblacional y condiciones climáticas más tropicales, dando lugar a una producción económica de frutas tropicales, de algodón y de mandioca. Por sus características geográficas las tierras son elegidas para realizar ganadería bovina. Vale aclarar que en toda la provincia se produce algodón, y es el cultivo más tradicional de la provincia, aunque ahora comenzó a ser remplazado por el cultivo de la soja y el trigo.

La provincia cuenta con una importante presencia de población aborigen, principalmente habitan tres etnias, en el oeste viven los Wichis, en el centro norte los Pilagá, y en el este y sur-este se ubica el pueblo Toba Qom. En cuanto a la población rural, según datos estadísticos del Censo Nacional Agropecuario, para el 2002, hay alrededor de $50 \%$ de "unidades" campesinas, por sobre el total de explotaciones agropecuarias. ${ }^{116}$ 
Varias investigaciones, resoluciones de organismos internacionales de medición y disciplinamiento de la pobreza, al igual que los centros de estadística pública nacional, coinciden en posicionar a Formosa como la provincia más pobre de argentina. Y esto se deduce desde su alta tasa de mortalidad infantil, su grado de analfabetismo, la situación precaria en cuestiones de hábitat (pocas viviendas, en mal estado; esto deriva en hacinamiento y problemas de salud), políticas sociales mal gestionadas y utilizadas bajo mecanismos de selección no universal o focalizadas, cuenta con un sistema de salud deteriorado e inapropiado, un alto nivel de desempleo y empleo informal, políticas municipales y provinciales de estrategia clientelar que promueven la vulnerabilidad social. Además sus vías de comunicación están en mal estado, y parecen inexistentes en muchas zonas rurales.

La provincia de Formosa en tanto su ruralidad presenta un deterioro y ausencia de servicios básicos, tiene una llegada escasa de políticas públicas. Está sustentada en una economía a base de extracción de materias primas (oleaginosas, cereales, madera, carne) con nulo valor agregado, con un tipo de empleo informal y en condiciones serviles. Presenta un serio avance en la concentración y expropiación de tierras, por parte de los nuevos actores del modelo agro-industrial, generando una masiva deforestación de bosques nativos, para la instalación de cultivos a gran escala. Es así la llegada del modelo del agro-negocio, que se viene dando a lo largo de estos años un sostenido ascenso de la soja transgénica, como también sucesivos intentos técnicos y de maquinarias para poder industrializar la cosecha de algodón, que tradicionalmente fue y es hecha a mano hombre. Este proceso genera un deterioro en las economías de los poblados rurales, pues ya se necesitan menos trabajadores por hectáreas. La expropiación de los bienes comunes naturales (bosques, selvas, especies animales) a través de la depredación de los bosques originarios para agricultura intensiva, conforma una destrucción de los sistemas ecológicos y una re-estructuración social. ${ }^{117}$

En consonancia con lo planteado anteriormente, existe una precariedad en la tenencia de la tierra, por parte de los campesinos y productores rurales de baja escala, que sufren

117 D. Dominguez, P. Lapegna y P. Sabatino, “Agriculturas en tensión en Colonia Loma Senés” en Giarracca, Teubal "El campo argentino en la encrucijada. Estrategias y resistencias sociales, ecos en la ciudad”. Alianza Editorial. 2005.

Vinuesa, Juan Diagnóstico Integral Oeste Formoseño. Ediciones INTA. 2007. Chiarulli, Simón, Machado, Soto, Vigil, "Cambiando de rumbo. Reflexiones sobre desarrollo sustentable de las familias de pequeños productores rurales argentinos”. INCUPO FUNDAPAZ Be.Pe. Red Agroforestal Chaco Argentina SUR. 2005

Informe Ejecutivo "Conflictos de Tierra y Medioambiente en la región del ChacoArgentino" Red Agroforestal Chaco Argentina (REDAF). 2009.

INDEC Instituto Nacional de Estadísticas y Censos. 2010. 
desalojos, presiones de ventas a bajo precio, promoviendo así un desarraigo rural y una inmigración a los cordones de pobreza de los centros urbanos. ${ }^{118}$

\section{EI INTA de Formosa}

La región formoseña, acompañó el desarrollo algodonero de la provincia del Chaco de los años '1930 y '1940. En la zona centro sur de Formosa se ubicaron distintas industrias desmotadoras ${ }^{119}$, logrando generar una activación económica productiva. Fue en esta región donde el Estado comenzó, desde sus áreas y secretarías agropecuarias a establecer chacras experimentales, investigaciones, para mejorar el rendimiento de este cultivo. El 24 de febrero de 1939 se inaugura una chacra experimental en El Colorado, perteneciente a la Junta Nacional del Algodón, donde se creó una desmotadora oficial. Años después en 1946 se separó a la Chacra Experimental de la desmotadora oficial; este último continuó bajo la Junta Nacional del Algodón, en tanto la Chacra Experimental, ahora ya como Estación Experimental, pasó a la órbita del entonces Ministerio de Agricultura y Ganadería de la Nación.” (Schaller, Alberto $2007^{120}$ ) Al crearse el INTA en 1956 la Estación Experimental pasa a formar parte de este Instituto.

Desde su creación fue abocada a la tarea de producción, adaptación y rendimiento de cultivos agrarios. También fue dedicando sus trabajos a la ganadería bovina y caprina. Fueron conformando su planta profesional, distintas personas provenientes de diversos puntos del país, especializados en cuestiones agro-pecuarias.

118 En cuanto a la marginalidad estructural, la vulnerabilidad social de Formosa, puedo agregar una cuestión desde el aspecto simbólico. En mi experiencia cotidiana, pude observar una invisibilización con respecto a la presencia que tiene la provincia de Formosa en mis relaciones personales y profesionales de Buenos Aires. Cuando vivía en Formosa, cada tres meses viajaba a Buenos Aires para encontrarme con mi gente querida; es ahí donde se repetía una extraña confusión, nadie daba en el blanco, nadie, todos me preguntaban cómo andan las cosas por "Mendoza", "Misiones", o "Chaco". Esto se repetía en todas las intervenciones hacía mí, y después de haber vivido tres años en la provincia de Formosa, es hasta el día de hoy que mis amigos familiares, compañeros de trabajo cometen este equívoco. Por eso desde esta mirada personal puedo dar cuenta de la invisibilidad que opera sobre la provincia de Formosa, como una arista más de su precariedad.

119 Desmotadora: industrias que trabajan separando rápidamente las fibras del algodón cosechado, de las vainas y las semillas, acopiando así la materia prima.

120 Schaller, Alberto. "Aniversario de la Estación Experimental "El Colorado" del INTA". Ediciones INTA. El Colorado, Formosa, 2007. 
Entre las muchas miradas de análisis que podemos atender sobre el INTA, podemos decir que tiene una desigual distribución de sus recursos profesionales y materiales en el territorio nacional. La Unidad de El Colorado, tiene designada cómo área de influencia la provincia de Formosa y el departamento Gral. San Martín de la provincia del Chaco. Tiene así adjudicada el 47\% del territorio total que conforman Chaco y Formosa, pero tan sólo tiene una Unidad Estación Experimental Agropecuaria, mientras que en el Chaco hay 3 Experimentales para esa provincia. Además a nivel nacional podemos notar que la provincia de Buenos Aires posee un total de 12 Estaciones Experimentales, teniendo en cuenta también que es donde se ubican los institutos de investigación más importantes del INTA. Esto viene a consonancia con la estructuración histórica del país, donde se privilegio la política agropecuaria en los centros de más alta producción, no en aquellos con escaso "progreso" e "inmadurez productiva". Frente a esta situación, el trabajo es mucho y los recursos pocos, generando así proyectos focalizados, que no pueden tener un trabajo más integral.

La Estación Experimental Agropecuaria (EEA) El Colorado del INTA posee dos grandes áreas de trabajo: Investigación y Extensión (como todas las unidades EEA del INTA) En el predio central ubicado en la ciudad de El Colorado, se ubican los ensayos y los laboratorios del área de investigación. El área de Extensión trabaja con distintas unidades de extensión (agencias y oficinas) ubicadas en distintas localidades del área de influencia. Aquí aparece una desigualdad interna, ya que en el oeste de la provincia donde la vulnerabilidad social es más profunda, hay menor institucionalidad operativa, en cambio en el centro-este se ubican la mayoría de las agencias y proyectos de extensión. En cada unidad de extensión hay por lo menos un integrante profesional agropecuario, que "articula" los proyectos regionales y nacionales del INTA en la localidad. La EEA El Colorado del INTA posee 10 unidades de extensión, 6 agencias de extensión rural (Formosa, Laguna Blanca, Güemes, Ibarreta, El Colorado, Gral. San Martin), y 4 oficinas de desarrollo rural (Pirané, Pampa del Indio, Las Lomitas, Ingeniero Juárez). Dentro de la Coordinación del área de extensión, se ubica el Grupo de Comunicación y Capacitación, desde donde trabajo mi beca. Este área ha sufrido los vaivenes antes analizados en cuanto a comunicación rural, extensión, e intervención. 


\section{3.:Otro sujeto destinatario es posible en el INTA Formosa?}

Como hemos analizado en los componentes anteriores el INTA diferencia y construye tipos de destinatarios según su escala productiva; a éstos los agrupa para hacer llegar la asistencia técnica profesional. Evidente es que además de suprimir aspectos y convocar actores sociales desde su capacidad empresaria, deja de lado a otros actores de peso en el mundo de la ruralidad. Entre esas ausencias se encuentran las organizaciones populares, los movimientos sociales, sujeto colectivo que no es abordado como tal por la política pública agraria del INTA. $^{121}$

Dentro de los programas que el INTA de Formosa dispone tanto en investigación y extensión ninguno está dirigido a las organizaciones sociales presentes en el medio rural del área de influencia. El programa que articula, más por vocación social de los profesionales que por mandato institucional es el Pro-Huerta, que es originariamente destinado a personas con necesidades básicas insatisfechas. El INTA dispone de una cantidad de recursos para investigaciones, profesionales desarrollando ensayos y productos para sostener el modelo del agronegocio, como hemos dado cuenta anteriormente.

Con esto quiero descifrar que el INTA apoya, sostiene y reproduce las condiciones del modelo del agro-negocio y deja como política de subsidiariedad a un programa con escasa dimensión presupuestaria y posibilidad de acción (Pro-huerta). Los trabajadores de Pro-huerta de Formosa han estado más de 10 años bajo régimen informal de contrato laboral, por fuera de la planta del INTA, y sufren además el estigma de ser considerados como técnicos de segunda escala, por detrás de los técnicos investigadores, pues trabajan para el "chiquitaje" 122 , o "pobrerio rural".

Un nuevo interlocutor puede emerger como destinatario de la "llegada" de las políticas agrarias del INTA. Ya no un sujeto preformado desde el Instituto y bajo un reduccionismo

121 Que a diferencia de la estructura de destinatarios que conforma el INTA, como en el caso de Programa Cambio rural, donde agrupa a productores de mismas condiciones; estas organizaciones ya están convocadas anteriormente a cualquier intervención estatal, y poseen dinámicas propias, no consignadas por un agente exterior.

122 Refiere despectivamente a la escala de producción de esos pobladores. 
economicista, en tanto productor, empresario agrario, sino un actor colectivo socialproductivo ya conformado, las organizaciones comunitarias y los movimientos sociales. Es así que intentaremos dar cuenta de algunos de ellos, para después trazar algunas líneas de reflexión y también de acción para trabajar comunitariamente en pos de fortalecer y acercar las políticas públicas al servicio de los colectivos sociales en zonas peri-urbanas y rurales.

Lo que a continuación se presenta son una suma de relatos de experiencias que tuve la oportunidad de visitar, pasar tiempo con, conocer, buscar y acercarme en mi estadía en Formosa. He seleccionado algunas entre varias a los fines dinámicos de este trabajo. Los modos de acercamiento fueron visitas en territorio, entrevistas semi-estructuradas, y talleres de reflexión dialógica y participativos.

La idea es ir pensando cómo conformar una relación entre estos actores colectivos y la beca para promocionar y producir instancias de trabajo comunicacional con ellas, fortaleciendo así la trama comunitaria de las zonas rurales y periurbanas de Formosa.

\section{Ferias Francas}

Las ferias francas son una estrategia y organización que cuentan los campesinos y los agricultores de pequeña escala para poder hacer frente al despojo del mercado por sobre sus productos y economía de baja escala. Los campesinos en el esquema de distribución, quedan en una posición asimétrica para poder obtener un precio justo, quedando además por fuera de las ganancias que la distribución genera. De esta manera los mismos productos que son trabajados por ellos, son llevados a un espacio común en el centro de la ciudad o frente a la plaza del pueblo, dos veces por semana a la mañana creando así una Feria Franca. Entre las distintas ofertas encontramos: vegetales, frutas, hortalizas, legumbres, semillas, panificados, plantas, plantines, productos lácteos, dulces, conservas, licores, miel y derivados, artesanías, carne, comidas hechas, y textiles.

Es interesante notar que los productos elaborados en la zona son consumidos en la misma zona, promoviendo así el empleo rural y la presencia de nuevas dinámicas en el territorio. Muchos de los feriantes conforman un grupo sólido, dialógico y democrático en el ámbito laboral, donde desde este potencial organizativo logran gestionar y conseguir resoluciones municipales, uso de espacios públicos, construcción de puestos, sanitarios en la 
feria, entre otras cosas. Entre los mismos feriantes es habitual que exista el trueque, intercambiando distintos productos sin intermediación del dinero.

Las Ferias Francas crecieron en Misiones, pero prontamente se replicaron en todo el país. Es en el noreste argentino donde más expansión han tenido. Por lo que he recorrido puedo dar cuenta que en la Provincia de Formosa, las Ferias se fueron expandiendo a través de conocer otra experiencia en otro lugar. También son algunas derivadas de los años del trueque de la crisis del 2001. Muchos feriantes están de acuerdo en resaltar las buenas relaciones que se generan en la feria, "somos como una familia, hay mucha confianza",123

En la provincia de Formosa existen 13 ferias francas. La mayoría ya consiguió la personería jurídica y el armado de su estatuto.

\begin{tabular}{|l|l|}
\hline \multicolumn{1}{|c|}{ Feria } & \multicolumn{1}{c|}{ Localidad } \\
\hline Feria Franca El Espinillo & El Espinillo \\
\hline Feria Franca Belgrano & Pirané \\
\hline Feria Franca Pirané & Pirané \\
\hline Feria Franca El Colorado & El Colorado \\
\hline Feria Franca Las Lomitas & Las Lomitas \\
\hline Feria Franca Gral. Manuel Belgrano & Gral. Manuel Belgrano \\
\hline $\begin{array}{l}\text { Feria Franca de pequeños productores } \\
\text { Paiperos }\end{array}$ & Villa Dos Trece \\
\hline Feria Franca Villafañe & Villafañe \\
\hline Feria Franca Clorinda & Clorinda \\
\hline Feria Barrio La Paz & Formosa \\
\hline Feria Barrio Eva Perón & Garabí \\
\hline Feria Franca Palo Santo & Palo Santo \\
\hline Feria Franca Misión Tacaaglé & Misión Tacaaglé \\
\hline
\end{tabular}

El espacio que recrean las ferias francas es una instancia de comunicación, donde el diálogo entre los feriantes y los vecinos, y entre los mismos feriantes, se da de modo fluido, recreando en cada feria un encuentro social. Hacia dentro de la organización se toman decisiones de modo democrático en las reuniones y asambleas correspondientes. La mayoría de las ferias tienen poca relación con el gobierno provincial, pero con el gobierno municipal se hace necesario instaurar un diálogo para gestionar recursos y espacios. Por último vale aclarar que las ferias francas muestran interés de profundizar e inaugurar, según el caso, la articulación 
con el INTA.

\section{Feria de Semillas}

Bajo la defensa y consigna de que las semillas son definitivamente un bien común, se viene realizando a nivel nacional las "ferias de semillas nativas y criollas", con el mismo espíritu cooperativo que las ferias francas anteriormente descriptas. Pero, a diferencia de las ferias francas en este espacio no hay dinero de por medio, pues todo es intercambio, trueque de material.

"Vos me das una semilla tuya, de tu producción, y yo te doy la mía, es intercambio, no las vendemos" $" 124$

"Todos tenemos que tener acceso a la semilla. Es un patrimonio colectivo. Y la venta muchas veces limita a aquellos que tienen menos recursos económicos. En cambio en el intercambio si vos no tenés una semilla podés tener un plantín, o una mermelada, un licor o, un abrazo. Yo te regalo algo y vos me regalas algo, no importa cuánto cuesta.

El intercambio garantiza el acceso a la semilla. Cuando yo era chica, era una cosa común. Después perdimos esto. Fue el proyecto neoliberal que destruyó la cultura de la producción y el intercambio, e instaló la sociedad de consumo muy fuerte. "125

Estas semillas son nativas y criollas, fruto de años de reproducción y siembras cuidadas de forma natural por los campesinos sin el uso de agroquímicos. Este movimiento busca contrarrestar con las banderas de la soberanía alimentaria, la biodiversidad y la economía

124 Entrevista Romina Gonzales. Feriante Feria Nacional de Semillas. INTI.

125 Entrevista a Alicia Alem, Feria Nacional de Semillas. Bs. As. 2011 
solidaria a la propuesta del modelo del agronegocio y su mercado y comercialización de semillas transgénicas y patentadas. Este último modelo torna dependiente a quien compra la semilla, pues debe adquirir el paquete tecnológico a alto costo (semillas, agroquímicos), y por la regulación de patentes debe comprarlo así todos los años.

Varias familias de campesinos y miembros de ferias francas de la provincia de Formosa participan de las Ferias Regionales, y ferias locales de semillas. En la tercera edición de la feria regional de semillas realizada en General San Martin, provincia del Chaco, participaron miembros de la feria franca de El Colorado.

\footnotetext{
"Trajimos semillas de maíz, diferentes tipos de porotos, de café, todo para intercambiar. Pero también preparamos mermeladas de zanahoria, de calabaza, dulce de leche, quesos caseros. Todo producción propia, en familia, sin nada artificial. Hasta la esterilización de los frascos lo hacemos en forma natural, sin ningún producto químico". ${ }^{126}$
}

Fue en el 2009 que se realizó la primer feria de semillas dentro de Formosa, en la localidad de Herradura, donde familias campesinas y pequeños agricultores intercambiaron semillas de batata, melón, maíz, zapallo, poroto, ramas de mandioca.

\section{Salud Comunitaria I}

Durante la crisis del 2001, en la localidad de Ingeniero Juárez, en la provincia de Formosa, un grupo de personas se organizó para elaborar remedios caseros, atendiendo a la emergencia sanitaria que atravesaba el país, donde era sumamente difícil conseguir medicamentos, o incluso poder comprarlos. Es así donde un conjunto de vecinos de la localidad, y con el apoyo de distintos profesionales comprometidos socialmente de distintos programas públicos, comenzaron a elaborar remedios caseros, a partir de la creación y fortalecimiento de una organización, Semillas de Vida. Establecieron no vender los remedios sino que iniciar un trueque, uno se lleva el remedio y ofrece algo.

"Estos remedios no se venden ni se regalan; se "cambian" por algún elemento necesario para su elaboración (plantas, azúcar, alcohol, grasa, etc),

126 Entrevista a Oscar Maimó, campesino miembro de la Feria Franca El Colorado, Formosa. Entrevista hecha y publicada por Jorge Solari, Incupo. 
asegurando de este modo la sostenibilidad de esta propuesta", 127

Tal fue el emprendimiento que desde la crisis antes mencionada, hasta la actualidad los médicos del hospital zonal recetan estos medicamentos a los pobladores. Dos de sus participantes más involucrados dan cuenta de

"el hecho de revalorizar y rescatar saberes populares muy arraigados en nuestra gente y poco reconocidos o invalidados hasta el presente... es un pequeño paso para poder hablar de la salud en manos de la comunidad" 128

\section{Salud Comunitaria II}

La organización Salud para Todos nació en Laguna Yema bajo la necesidad de conseguir una ambulancia para poder hacer los traslados de urgencia al hospital zonal en las Lomitas (100 km de distancia), o hacia el hospital central en Formosa capital que implica más de 300 kilómetros de distancia. Laguna Yema es la localidad cabecera del departamento Bermejo, donde habitan alrededor de 3.000 personas. Es una localidad muy precaria y marginada. Hace un par de años el hospital de la localidad no contaba con equipamiento para atención de emergencias, entonces los yemeños ante un eventual accidente u enfermedad debían trasladarse por sus propios medios a los hospitales centrales.

\footnotetext{
"No teníamos ambulancia en el Hospital, y en ese entonces no había asfalto. Este Hospital no atiende todas las especialidades y tampoco muchas urgencias." 129
}

Entonces la hermana Andrea, misionera de la orden franciscana, comenzó a organizar a los vecinos para empezar a dar respuesta a la problemática de la salud. Así se fueron sumando varias personas, que gestionando y peticionando consiguieron una ambulancia donada por una organización no gubernamental de España. Más tarde y con más donaciones consiguieron un laboratorio para el hospital local, como también un predio y edificación para la sede de la

127 Patricio Sanz, María Inés Cavallero, "Imágenes de una Actividad Solidaria. Elaboración de remedios caseros para la comunidad" Grupo Semilla de Vida, 2003.

$128 \quad$ Idem.

129 Juan Perez, presidente de la asociación Salud Para Todos. Entrevista hecha para esta tesis. 2007. 
organización. Otro aporte es la cuota social que pagan los asociados mensualmente de 5 pesos.

Hoy en día es una asociación civil que cuenta con 100 socios, de los cuales 13 conforman su comisión directiva. Su objetivo es promover el mejoramiento de la salud en la localidad.

\begin{abstract}
"Nuestro objetivo era y sigue siendo la de mejorar el servicio de la salud de la gente más necesitada y subsanar falencias en tema salud. Todos los socios comenzaron a aportar la cuota de colaboración.[...]

En el caso del uso de la ambulancia que es abierto para todos, la organización consigue la plata para pagar el chofer, y hay que buscar quién financia el combustible." 130
\end{abstract}

En el 2007 comienzan con un proyecto con fines productivos para generar trabajo, donde buscan llevar adelante una fábrica de harina de algarroba con la ayuda de una ONG en Buenos Aires. La algarroba es el fruto del árbol del algarrobo, muy presente en la zona. Esta chaucha tiene muchos nutrientes, los aborígenes la consumen, como también es utilizado para el engorde de ganado. El proyecto propone que la chaucha sea recolectada por un grupo de aborígenes y campesinos que la venden a la asociación. Después la asociación se encarga de producir harina, envasarla y comercializarla. En este último punto sinceran tener problemas, y esperan poder articular en algún momento con el INTA.

Otro de los proyectos con respecto a salud social es el Proyecto Botiquín Comunitario, que fundó la hermana Andrea, que es enfermera. Ella da cuenta de que uno de los problemas estructurales es la gran exclusión entendiendo que

\begin{abstract}
"La persona de Yema se siente inferior, es introvertida. Todos los que vienen acá, vienen a explotar pobladores. Quieren organizarlos para sacarles. Nosotros buscamos que la gente de acá pierda su complejo de inferioridad, que sean capaces de hacer una organización por ellos mismos, donde en la Asociación le den integración a los aborígenes." 131
\end{abstract}

Es ahí que propone constantemente la organización como modelo para salir adelante. El proyecto Botiquín Comunitario se asemeja al de Semillas de Vida de Ingeniero Juárez, pues propone conformar remedios originarios para facilitarlos a los que menos pueden comprar

130 Ana Gonzáles en el taller participativo de reflexión organizacional llevado a cabo para esta tesis. 2007.

131 Entrevista Hermana Andrea. 2007. Para los fines de la tesis. 
medicación. Lograron que el Hospital local recete jabones y cremas producidos en este botiquín. También realizan antiparasitarios, cremas medicinales y tinturas.

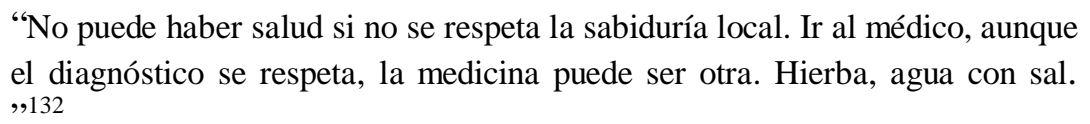

Andrea comparte con alegría que los remedios a base de ruda (planta medicinal y aromática) sirven para combatir los piojos, y se donan a las escuelas de la zona.

Actualmente a la organización le cuesta superar el plantel de personas comprometidas, a la vez aclaran que la comunicación y llegada con todos socios debe ser revisada. Las personas que trabajan en la organización pertenecen a la comisión directiva. Hacia dentro de la comisión las decisiones se toman de modo participativo, y se logra llegar a un consenso antes de implementar la votación. Una vez al año realizan una asamblea para renovar las autoridades, en donde están invitados a participar todos los asociados. No tienen una relación y vínculo sostenido con el gobiernos local y provincial.

\section{Mocafor}

En las localidades de General Belgrano y Misión Tacaglé nace a fines de 1990 el Movimiento Campesino Formoseño (MOCAFOR), en medio de una crisis económica y social profunda. Se consideran herederas de las luchas y resistencias de las Ligas Agrarias, y el Movimiento Agrario Formoseño (MAF). Con respecto a este último movimiento se separaron al entender que son otros los intereses que persiguen. El MOCAFOR se fue organizando a través de distintos grupos zonales de familias de campesinos y aborígenes, muchos de ellos sin experiencia organizativa previa. La iglesia católica con el movimiento tercermundista ayudaron en los primeros momentos a encaminar la cuestión. Más tarde los miembros del MOCAFOR fueron expulsados de la Iglesia Católica, por cuestiones de propuestas de transformación y reclamo. A partir del 2002 comenzó a expandirse la organización al territorio formoseño.

Se organizan de forma autónoma, y tienen asambleas para resolver y planificar los 
proyectos y los reclamos. Se sustentan con el aporte de sus miembros y simpatizantes. "Los que más tienen suelen poner más, pero todos, la mayoría colabora con algo" "133. Sus acontecimientos más importantes son la lucha diaria por la tenencia de la tierra, por frenar el desalojo de campesinos y aborígenes de sus tierras ancestrales, para combatir así el constante desarraigo rural. Se proponen así lograr una economía que sustente al campesino y su familia en la chacra, sin necesidad de vender o irse del campo por falta de oportunidades.

En julio de 2005 el MOCAFOR organizó una gran marcha por tierra, trabajo y democracia desde la Localidad de General Belgrano hasta la ciudad de Formosa para entregar un petitorio a las autoridades provinciales y poder dar a conocer la realidad en la cual están los campesinos y aborígenes. En cada pueblo o localidad donde frenaban, visitaban los barrios más carenciados para interactuar y sumar demandas a la marcha. El recorrido fue intenso y se realizó por las rutas provinciales; implicó alrededor de 300 kilómetros que fueron hechos en 3 semanas. Entre sus motivos para marchar aparecen: la reivindicación de los derechos de los campesinos, para frenar la concentración de tierra en pocas manos, por la devolución de tierras expropiadas a las comunidades indígenas, por más presupuesto en salud y educación pública, para regularizar y limitar las producciones transgénicas, para poder acceder a los servicios básicos en las comunidades rurales, por el precio justo de las producciones campesinas, defensa de los recursos naturales. (Parte MOCAFOR, 2005)

Bajo la consigna Tierra, Trabajo y Democracia, participaron más de 500 personas entre ellos militantes de movimientos sociales, religiosos, de derechos humanos, de pueblos originarios, de organizaciones comunitarias y vecinos que apoyaban la medida. Arribaron el 17 de agosto; sus reclamos hasta el día de hoy no fueron atendidos.

Hace dos años han comenzado con la idea de conformar cooperativas integrales (de compra, de trabajo, de consumo, de producción, de educación) para fortalecer la organización y sus fines. Es así que en la localidad de General Belgrano se encuentra el galpón, sede central de la Cooperativa Coe`yú, que en guaraní significa Amanecer. Están en plena organización de la misma; ya cuentan con maquinaria agrícola que se alquila a los socios a bajo costo para la siembra, y la cosecha. Se muestran entusiasmados con el proyecto y ya comenzaron a realizar una huerta orgánica en el patio de atrás. 
Su definición ideológica no está estructurada desde un marxismo ortodoxo, sino que en su reivindicación campesina y de transformación social se reconocen como "guevaristas cristianos". MOCAFOR mantiene buenas relaciones con otros movimientos campesinos y sociales, compartiendo varios encuentros nacionales. En cuanto al estado provincial no tienen más que una relación de tensión y desatención, con respecto a algunos organismos de la política nacional tienen más llegada para financiar algún proyecto. Es en cuanto a lo provincial que sufren un constante hostigamiento a través de la criminalización de la protesta social. Tienen varios miembros con causas judiciales abiertas.

"Dentro de Formosa estamos cercados, discriminados, perseguidos. Incluso las ONGs y los programas sociales preguntan primero cuál es nuestra relación con el gobernador antes de entablar un diálogo porque saben que si apoyan los emprendimientos del MOCAFOR son perseguidos políticamente." ${ }^{134}$

Por último doy cuenta de una situación que me llamó la atención en los distintos encuentros, y es la predisposición al trabajo que tenía uno de sus miembros entrado en edad, Don Fulgencio Pérez, miembro fundador de MOCAFOR. En una mateada bajo un árbol de mango, Fulgencio me convidó parte de su historia, cuando se dio cuenta que organizarse valía la pena. Cuenta que campo adentro, de donde él es, en una época en la escuela donde mandaba a sus nietos, la directora "hacía su trabajo con la partida del comedor", destinaba la plata a otros fines.

"Ahí nos organizamos todos para encararla, y fue ahí que nos dimos cuenta, que juntos nos podríamos defender los pobres." 135

Aunque lo ven difícil por lo anteriormente expuesto, los dirigentes del MOCAFOR están interesados y demandan asistencia técnica para los campesinos.

134 Entrevista Benigno López por Silvia Biancardi, Encuentro de Jóvenes por la Tierra, 2006

135 Entrevista Fulgencio Pérez, hecha para los fines de esta tesis. 
Una de las iniciativas que pude llevar a cabo durante esos años fue el Proyecto de Acompañamiento Organizacional (PAO), que guardaba como principal objetivo el poder acercarme, conocer y dialogar con actores comunitarios que no entraban en el marco destinatario del productor empresarial, o grupo de productores empresariales que referían los planes más importantes y de mayores recursos destinados del INTA. Al entrar en contacto con los referentes organizacionales me di cuenta de que había un diálogo, un ida y vuelta quebrado hacia dentro de las organizaciones, es así que nació la propuesta de ampliar y desarrollar espacios de comunicación, de reflexión interna hacia dentro de las organizaciones. Otro objetivo que surgió fue el de compartir y hacer circular distintas herramientas organizacionales y comunicacionales a estos actores comunitarios.

Participaron varias organizaciones con distinto grado de compromiso durante el año 2007 y 2009. Para los fines de esta tesis, propongo sistematizar una de ellas, que considero que asumió la idea planteada de un encuentro. Recorreremos entonces un recorte de los aportes y los debates internos llevados a cabo en los encuentros realizados con la Asociación Civil de Criadores de Conejos, Aves y Abejas de Villafañe, ubicado en la localidad de Villafañe del departamento Pirané. ${ }^{136}$

Les propuse en primera instancia a la asociación realizar una reflexión comunicacional de la organización ${ }^{137}$, tomando en cuenta la historia recorrida, el presente y alguna proyección de acción. Se realizaron alrededor de 10 talleres, más otras visitas desestructuradas y de recorrido. Los primeros talleres fueron orientados para lograr un espacio para compartir ideas, objetivos, reflexiones, debates en la organización, y los tres últimos talleres fueron destinados a facilitar herramientas comunicacionales y organizacionales. Es así que el trabajo arrancó con el primer taller "Se hace camino al andar, la historia de nuestra organización." La idea de este taller es la de rescatar entre todos una historia de la Asociación, valorarla, ser críticos y desde ahí mirar el presente. Se necesitó afiches, fibrones para la consigna de que logren dar cuenta de la historia de la organización, por cuáles caminos anduvieron, qué trayectos realizaron.

136 Con la Asociación Civil de Criadores de Conejos, Aves y Abejas de Villafañe, conocí a su referente Gabriel López en uno de los pasillos de la experimental de Formosa, ahí enseguida coordinamos unos encuentros.

137 Para este Proyecto se hechó mano a la metodología del taller dialógico, desde donde se promueve la circulación de la palabra de los participantes para desarrollar una mirada más amplia sobre los asuntos de la organización. 
Surgieron interesantes miradas, por momentos como si hablaran de dos organizaciones distintas.

Vale resaltar que la asociación en cuestión desde el primer taller demostró un alto compromiso de sus miembros para con los encuentros, generando interesantes debates en cada uno de los ítems puesto en la mesa. Es así que fueron entre varios construyendo la historia de la asociación...

\begin{abstract}
"En el 2003 nos hemos juntado un grupo de vecinos, para ver qué podíamos hacer con la parte de cunicultura ${ }^{138}$. En ese momento fue un "boom" la parte de cunicultura. Entonces preguntamos, ¿quién se anima a asociarse, para ver que se puede hacer con la parte de cunicultura? Y ahí salió la asociación. En eso vinimos bien, caminando, desarrollando todo el proceso de organización que nos permitió tener la personería jurídica. En el 2004 tuvimos el mal tino, de involucrarnos con el municipio y empezar a proyectar algunos proyectos Jefes y Jefas de Hogar. Salió uno solo de los que presentamos. A partir de ahí de alguna manera, como no hubo respuesta en eso que hicimos, prácticamente entre 2005 y 2006 los muchachos bajaron los brazos. Pero a partir de la relación con el INTA ${ }^{139}$ empezó a gestarse el tema de la formación de una Feria Franca; hasta ahora se viene trabajando en esto. Arrancamos 55 feriantes y ahora somos 13. Tenemos un bajón total, pero es por la cultura de todos los productores y muchísimas cosas más. Hasta ahora hemos logrado avanzar. Tenemos más proyectos, pero están todos en vía, en camino, pero de a poquito vamos pateando las piedras, vamos zafando... se logró muchas cosas."
\end{abstract}

Ellos dan cuenta de que para estar en una Feria Franca y sostener un puesto se debe tener "vocación de feriante", y "muchos no lo tienen". La organización cuenta con cincuenta personas asociadas, de las cuales participan activamente unas diez. Hoy en día llevan a cabo el Banco Social, herramienta de apoyo a las producciones y emprendimientos locales; también organizan anualmente la Fiesta del Pequeño Productor. No poseen un lugar propio, ni infraestructura alguna, pero la escuela de Educación Superior les presta las aulas para juntarse. Ahí realizan la mayoría de las reuniones y asambleas para la toma democrática de las decisiones y elección de autoridades.

Con respecto a algunos obstáculos que aparecieron en el taller de la historia de la

138 Cunicultura, cría de conejos.

139 Algunas de estas prácticas ha articulado y articula con el Programa Pro-Huerta del INTA, a través de entrega de semillas y capacitación. Esto no contradice a lo que venimos sosteniendo con respecto a que las políticas focalizadas y estratificadas por sector guardan una desigualdad en cuanto presupuesto, equipos técnicos y lugares de decisión institucional. El programa Pro-huerta nace para los sectores más empobrecidos, programa que tiene llegada, pero presenta un techo a nivel alternativa para quebrar la inequitativa estructura rural. Desde este trabajo valoramos estos esfuerzos, y agradecemos la compaña durante las recorridas a varias organizaciones sociales. 
organización reflexionaron...

"Este camino parece un enripiado......los traspiés que estamos teniendo...por falta de comunicación, de integración. De una unión dentro del grupo.... por ahí, lo que nos está faltando un poco más de dinamismo en la parte de comunicación. La dinámica comunicacional creo que por ahí..., hay comunicación pero falta esa dinámica."

Asumiendo la demanda en cuanto a comunicación, en los siguientes encuentros primero estuvimos trabajando la idea del emprender con otros, qué implica organizarse, porqué lo hacíamos: y así surgieron varias respuestas...

“...Organizarse es parte de una necesidad, del ser común, la necesidad de estar compartiendo algo con alguien. Después hay otras necesidades, la económica, de todo tipo.

... La madre de todo esto es la pobreza. La pobreza es lo que nos mueve a tratar de salir en esto, la asociación.

... Pero tenés siempre las piedras en el camino y los obstáculos, que si no se te muere un familiar, que se te enferma el otro, que lo que haces no te alcanza, no te pagan lo que corresponde. Entonces ahí siempre estás pataleando. Yo me pongo de ejemplo con la edad que yo tengo, con el sueldito que tengo no me alcanza. Entonces yo tengo que estar siempre buscando una alternativa, y sola no puedo. En cambio así, asociándome, en una asociación sí. Porque estamos todos, los productos se venden en la feria, o nos vamos a los eventos. Que es una entrada. A parte de una entrada es una distracción. Conozco lugares que a lo mejor, yo sola no podría. En cambio todos juntos nos divertimos, vemos la cara de la gente, vemos el empuje de otra gente.

... Cuando uno ingresa en una organización, se asocia, debe desprenderse de sus intereses personales, los intereses conjuntos de una organización son los que deben primar.

... Y la palabra principal, que es el por qué el yo estoy acá es el conjunto, "el bien común". Creo que todo el mundo podemos. No hay gente que tiene que estar por debajo de uno. Tiene que tener la misma la capacidad de poder llevar un plato de comida al hijo como yo. Y hay cosas que yo me rebelo continuamente, la pobreza no la vamos a eliminar nosotros, pero en nuestro entorno, tenemos que luchar para eliminar la pobreza. Tenemos que luchar para que todos vivan bien, para que todos tengan lo mismo para vivir. Y tenemos que ayudarnos. Eso es lo que a mí me mueve a estar en esta organización.

... Ese es el proyecto de ser compañeros, de ser humildes, de estar juntos, de compartir."

En los siguientes encuentros muchos compañeros reclamaron que los problemas de la organización pasaban por la comunicación y la integración. En eso logramos conformar un taller sobre estos temas, el taller arrancó con la siguiente actividad:

"A través de una "tormenta de Ideas" hacer un acercamiento a: ¿qué 
entendemos por comunicación?

Se puso la palabra COMUNICACIÓN en un afiche en blanco y se pidió a los participantes que digan lo primero que se les venía a la mente. Lo que salía se fue anotado.

Afiche:

\begin{tabular}{|l|l|l|}
\hline Ida y vuelta & Coherencia & Lealtad \\
Fluida & Motivación & Inteligencia \\
Metodología (formas de cómo & Veracidad & Doble Compromiso \\
hacer las cosas) & Verdad & Diálogo \\
Respeto & Motivación & Solidario \\
Solícito & Vertical & Solidaridad \\
Planificación & Horizontalidad (Igualdad) & Colaboración \\
Ético & Desordenado & Trabajo \\
Democrática & Sólido & Plosibilidad \\
Humano & Compromiso & Cordialidad \\
Acción & Ittegración \\
Organizado & Compañerismo \\
Real & Idea & Activo \\
\cline { 2 - 3 } & Amistad & \\
\cline { 2 - 3 }
\end{tabular}

Durante el debate en plenario distinguían la diferencia entre comunicación interna y comunicación externa, y coincidían que si no hay comunicación hacia adentro de la organización, la comunicación externa es confusa. Durante estos meses organizaron una revista para entregar a los vecinos y así dar a conocer las actividades de la asociación (ver Adjunto).

A partir de ahí los siguientes encuentros trabajamos la herramienta "asamblea" y "reunión" para identificar dificultades y plantear estrategias frente a éstas. Propongo detenernos en una de las actividades que realizamos para ir desandando los espacios de trabajo y comunicación que están por fuera de los lugares establecidos de una organización formal. Otra lectura que suma fuerza en el proceso comunicacional, es reconocer los espacios y escenas donde la relación, la comunicación aparece en la organización. Pues muchas veces armamos encuentros, talleres en un espacio consensuado entre la organización y el trabajador 
de la comunicación, y otras son espacios que la asociación ya contiene en una "reunión semanal", en un "encuentro de discusión”. Pero éste no abarca el proceso comunicacional cotidiano de la organización; pues hay otros espacios de diálogo y encuentro que le son propios a la organización, donde es importante adentrarse para conocer plenamente el entramado de los actores en construcción de organización.

Fui invitado, y acepté a ir a trabajar en el armado de una huerta comunitaria que la asociación se propuso armar. Habíamos realizado un taller-encuentro sobre la reunión como instancia de comunicación en las organizaciones, un día jueves, y el sábado fui convocado para el trabajo en la huerta.

\section{Lo comunicacional desde una escena}

La escena puede describirse desde un sol que va creciendo durante el paso del día, que abraza-braza cada vez más o, desde la sombra del mango que nos recluye del trabajo para retomar fuerzas.

Parte de la organización se ha propuesto realizar una huerta comunitaria, para abastecer a la feria franca de hortalizas durante el verano. El sábado decidieron empezar a construir la media sombra al terreno donde sembrar. En esa zona rural se coloca la media sombra para proteger del sol y las heladas a los cultivos. "Tenemos que clavar unas palmas el sábado", me comentaron. De mi sabida ignorancia en el tema, supuse que las palmas eran algo livianas, fácil de trasladar y plantar. Cuando llegué al predio, me presentaron los troncos de palma, comentándome que eran pesados. Enseguida lo comprobé y, definitivamente era errado ese comentario, eran muy pesados. El trabajo consistió en trasladar, tracción humana, los 16 postes de palma hacia la huerta, cavar por cada uno un pozo profundo en tierra dura y seca, para fijarlos. Alzar las palmas fue lo más duro de la jornada, entre dos o tres debíamos trasladarlas. Intercalamos el trabajo al sol, con algunos descansos a la sombra del mango, planta favorita en la zona para brindar reparo al sol. En ese reposo surgían intercambios, mientras tomábamos unos tereré que refrescaban el asunto. Hubo un corte para comer el "guiso de pobres".

A lo que refiere a pensar lo comunicacional, en las distintas instancias había diálogo. Cuando estábamos trabajando el intercambio era más reducido, y se refería a indicaciones, 
mediciones, advertencias: "Cuidado con el alambre", a juntos decidir cuándo bajar de los hombros la palma para no lastimar a nadie. El esfuerzo físico y la concentración nos disponían el cuerpo para la escucha y habla deliberada.

En el momento de la sombra, la conversación se extendía y repartía. Ahí surgieron debates sobre la política provincial, el tráfico fronterizo, los planes sociales, la pobreza y otras cuestiones local-regionales.

Dentro de las distintas actividades y sus actores, como el trabajo era muy forzado, una de las mujeres que participa en el proyecto, vino a media mañana a preparar la comida. Otro de los compañeros, andaba con problemas en la espalda y se dedicó a repartir agua durante el trabajo. Entre todos y en tono de ironía lo apoderamos el "delegado", refiriéndonos a la cuestión estereotipada de lo sindical.

En el almuerzo, la charla creció aun más en la sobremesa, donde se habló de la problemática de una colonia vecina donde el cultivo industrial de la soja había afectado a la población con los pesticidas que tiran, de los animales del monte que siguen estando y los que están en peligro de desaparecer. Se hizo una interesante distinción entre los distintos "bichos del monte". Pude notar que en los espacios de descanso se planificaba la actividad, se proponía hasta donde se iba a llegar ese día y qué debería hacerse en las próximas semanas.

Por último, doy cuenta de una situación que puede resumir la tensión de saberes presentes en el medio rural. En una de las visitas a territorio, uno de los miembros más comprometidos de esta organización, Don Gabriel me acompañó a dar una vuelta por las casas de sus compañeros de asociación, para dialogar un rato con ellos, y comentarles las actividades que se iban a realizar en esos días. Tomamos unos ricos mates con pan dulce cocinado a horno de leña en lo de doña Alcira, en su casa. Alcira es feriante del pueblo y siempre prepara panificados para llevar. En eso ella sacó el tema de la luna y la cosecha, cuando estábamos justo hablando del proyecto de la huerta comunitaria que la asociación pretende desarrollar. Ella me comentó que ellos miran a la luna y se fijan en ella para realizar distintas actividades en la huerta, algunas semillas y plantas se siembran cuando la luna está llena y otras se colocan en otro estado de la luna. "Si no nos fijamos en eso, la mandioca sale dura, en otras plantas pueden venir los bichos". Don Gabriel descree de eso y doña Alcira le replica entonces "Vos pensás como los del INTA, que no creen en eso, pero es asî’. Terminada la mateada y 
caminando para otra visita, refloté el debate con Don Gabriel. Él me comento que mucho no creía en eso, pero que lo respetaba porque era la tradición de las personas del pueblo.

Una vez más, saber científico y saber popular se encuentran para disputar o relegar prácticas. Y esto es algo, que desde una mirada de planificación desatada desde lo comunicacional, se debe prestar atención. Los distintos modos de construcción e interpretación del mundo, las distintas creencias, entran en juego, relación, tensión, acallamiento, distancia, en todo momento. El saber científico ha ganado varias batallas en el mundo rural, y muchos agentes de extensión sostienen y replican hacia los pobladores rurales está mirada única del modo de hacer las cosas; pero lo tradicional, el saber rural popular, resiste algunos embates.

\section{Puesta en valor}

Clasificar a estas prácticas sociales desde un economicismo (como el INTA ordena sus destinatarios), no es reducirlas, sino más, negarlas. (¿Son Pequeños Productores? ¿Son Grandes empresas? ¿Son acaso Medianos productores?.) Dentro del esquema neoliberal que aun pesa en la institución, estas organizaciones sociales no entran como destinatarios, escapan al reduccionismo de empresas de economía productivista rural. De ahí la idea de retomar una sociología de las ausencias para lograr visibilizar desde la institución aquellos movimientos y construcciones colectivas que se tensionan con el modelo neoliberal rural.

Estos movimientos y organizaciones entran en relación con otros actores. Como hemos nombrado poseen en su mayoría buena relación con los técnicos del Pro-Huerta, donde algunos son miembros de dichas organizaciones. Éstos proveen con gran esfuerzo capacitación en huerta y granja, en zonas donde la sequía, la ausencia de agua y la imposibilidad de alimentar animales es moneda corriente. Como hemos observado algunas de ellas articulan con organizaciones no gubernamentales, por sobre todo para conseguir recursos (infraestructura, mobiliario, ambulancia).

Si bien es dispar la relación que tienen estos actores con el gobierno provincial, en su 
mayoría no articulan proyectos. Son la bajada de los programas nacionales los que más se suscitan en el territorio de las organizaciones. El movimiento campesino formoseño en su actitud de denuncia, su lucha incansable por los derechos campesinos y aborígenes encuentra una resistencia política y coercitiva por parte del gobierno provincial. ${ }^{140}$

Aquellas que tensionan más claramente la relación con el modelo del agronegocio son las ferias francas, la feria de semillas y el MOCAFOR. Las ferias francas revierten el modelo de producción-distribución-consumo de la renta neoliberal, conformando así mercados populares donde hasta se evita en algunos intercambios, el uso de dinero. De esta manera recrean el trabajo rural, los saberes tradicionales, y así el arraigo rural. Lo mismo ocurre con la Feria de Semillas, que despejando la opción del paquete tecnológico (semillas transgénicas-fertilizantespesticidas) ofrecen el acceso de todos a las semillas. Es el MOCAFOR el ejemplo más claro de esta tensión con el modelo imperante, pues postulan y trabajan desde el ser campesino, como identidad, con sus forma de labranza, su vida comunitaria, por sobre el modelo agro-industrial, que amenaza su posesión de tierras, su subsistencia.

Vale dar cuenta que a lo largo de estos años las organizaciones han pasado por distintas etapas en su trayecto, muchos de sus proyectos han quedado en el intento, otros se sostienen con grandes esfuerzos y sacrificios que hacen sus miembros; ya que la mayoría tiene uno o dos empleos informales, changas, y el tiempo escaso del descanso lo dedican a la organización.

Entre las actividades pendientes o proyectos estancados se encuentra la idea y necesidad de comunicar sus acciones a la comunidad. Si bien podemos dar cuenta de algunos intentos de boletines que no llegaron a repetirse en muchas de las organizaciones, fue la marcha por Tierra Trabajo y Democracia del MOCAFOR la que expresó un proceso comunicacional más intenso. Fue en sí una instancia de comunicación, de hacer visible los problemas de los campesinos y aborígenes del medio rural formoseño a la sociedad en su conjunto. El detenerse en todos los pueblos y dialogar cara a cara con los vecinos alimento este proceso. Esta fue una nueva metodología de comunicación asumida para "invitar al resto de la sociedad civil a tomar conciencia de la realidad de la población rural y la falta de políticas desde el gobierno; y tomar posición frente esta situación." " Aq1 Aqú la cuestión crucial que nace

\footnotetext{
140 "Para el poder político de Formosa, hasta una cooperadora escolar es vista como una amenaza. Cualquier intento de organización o solidaridad no lo toleran, lo persiguen y destruyen si pueden, con todos los elementos a disposición: la policía provincial, la Gendarmería, los medios de comunicación.” Benigno López, 2010. Documentado en Agencia de Noticias Biodiversidadla.

141 Benigno Lopez Marcha Tierra Trabajo y Democracia. Documentado en Argenindia.
} 
como inquietud de las organizaciones es cómo sostener estas prácticas de comunicación en el tiempo, como hacer vínculos sólidos con los vecinos.

En cuanto a los espacios de comunicación hacia adentro, éstos se dan en las reuniones, que suelen ser quincenales, en las asambleas, que se realizan cada seis meses, y en los espacios de trabajo organizacional. Por ejemplo, podemos entender a las ferias como un espacio genuino de comunicación, donde los vecinos que se acercan logran conocer a cada feriante, y además los feriantes entran en fuerte relación entre ellos. En estos espacios de trabajo y de diálogo surgen las propuestas, las revisiones a algunas decisiones tomadas en tanto feriantes, también circula la información local y provincial.

Estas experiencias contrarrestan el modelo empresarial y del agro-negocio que vinimos desarrollando en los otros componentes, disputando los rincones y márgenes del mundo rural; y es en este contexto de implementación de políticas neoliberales donde nacen estas organizaciones en respuesta a la exclusión estructural que presenta este modelo. Mientras que el esquema neoliberal promueve una agricultura intensiva, de grandes rindes, en donde la población rural no tiene lugar, salvo los pocos puestos de trabajo que ofrecen, las organizaciones comunitarias ocupan el territorio generando nuevas estrategias para sobrevivir y arraigarse en su ruralidad. Son experiencias basadas en una concepción humana de lo social, del respeto hacia la naturaleza en sus formas de producir, y parten de un fomento del trabajo en conjunto como articulador para denunciar y resolver problemas locales o regionales. Como hemos visto mientras que algunas de ellas asumen un rol más político, otras intentan desde lo más local, lo comunitario.

Son esas experiencias que la modernidad llamó "atraso", en tanto su relación por fuera del economicismo productivo, las que resguardan y validan los saberes populares, las identidades regionales, y resisten así la adopción y empleo de los productos y paquetes tecnológicos del mercado, la usurpación de tierras, el desarraigo rural.

Lo más interesante es que en esa relación hombre-naturaleza, y hombre-hombre, intentan dar respuestas colectivas y solidarias a problemas estructurales comunes, teniendo una mirada crítica sobre las condiciones socio-históricas. No es que se auto responsabilizan de su pobreza (modelo de participación neoliberal), sino que generan estrategias para hacer actividades alternativas al mercado, y en algunos casos para demandar y luchar por derechos humanos. (Salud Comunitaria, Acceso a Tierras, Soberanía Alimentaria) 
Otra característica no menor, es la toma de decisiones ampliada que realizan todas las organizaciones presentadas; donde en un espacio de diálogo y comunicación (asamblea, reunión anual) toman las decisiones más importantes entre todos, y cada dos años renuevan las autoridades y responsabilidades de la misma de modo democrático. Esta democracia participativa, les permite generar consenso sobre las decisiones asumidas, y futuros proyectos, como así colabora en fortalecer la responsabilidad personal dentro de la organización.

Tal vez una cuestión a notar, por último es la poca articulación y relación que tienen entre sí las experiencias; esto se debe a: a)las grandes distancias que hay entre los parajes y pueblos, b) la sobre-ocupación laboral de sus miembros, donde la dedicación plena del tiempo disponible para la organización se lleva a cabo en la propia asociación, no disponiendo de más fuerza trabajo para conformar una red, c) no se conocen las fortalezas y llegada que una construcción aún más colectiva entre las distintas organizaciones comunitarias puede alcanzar.

Las organizaciones presentadas en este trabajo buscan la articulación con políticas públicas que les ayuden a potenciar su trabajo; dentro de las demandas surge en ellas la idea de entrar en mejor relación con el INTA, ya que la cuestión rural y agraria es la base de la mayoría de sus proyectos.

\section{Líneas de acción.}

A partir de lo trabajado, propongo entonces pensar algunas líneas de acción que puedan ir conformando una base para desarrollar una política integral hacia las organizaciones de base y comunitarias, que suplante la ausencia, o los proyectos focalizados existentes para la población rural campesina y aborigen. Todas estas líneas de acción están encaminadas a potenciar lo público, al servicio de los actores sociales de transformación colectiva de la realidad.

Las líneas de acción que se presentan; a) respetan la identidad y acción asumida del actor colectivo en la sociedad, evitando así focalizar en uno u otro aspecto de la organización; b) reavivan una tensión con el modelo del agronegocio, ya que están dirigidas a fortalecer las dinámicas de aquellos sujetos que quedaron excluidos o rezagados del modelo neoliberal agrario: c) parten de una propuesta crítica de la participación y la planificación, donde se 
asume una democracia intensa en todos los procesos de ejecución de las mismas, donde la toma de desiciones se lleva a cabo de modo plural.

Pero antes de plantear estas orientaciones, necesitamos cuestionar, y más después de lo descripto en este trabajo, si es posible dentro del INTA pensar un espacio para trabajar con las organizaciones sociales y fortalecer su dinámica. Esta tesis se alienta en pensar esta posibilidad, no en el plano de la conformación de una política pública nacional, sino en un proyecto del área de extensión, de una unidad específica del INTA. Este trabajo es a mi entender el primer paso para promocionar una apertura en este sentido, pues propone y orienta a pensar los procesos comunicacionales desde un esquema amplio y social por sobre el enfoque difusionista; generando así la posibilidad de argumentar desde un texto académico, tesis, sobre las nuevas maneras de pensar y hacer comunicación desde una unidad del INTA. Asumiendo los riesgos que esto implica, presento unas primeras líneas de acción.

$\checkmark$ Socializar la tesis. Promover un espacio de debate sobre el abordaje territorial y las ciencia sociales con los coordinadores de la unidad del INTA.

$\checkmark$ Profundizar el diagnóstico con las organizaciones.

$\checkmark$ Emprender una relación con destinatarios-interlocutores en tanto sujetos sociales y políticos. Saltear el reduccionismo economicista que plantean los proyectos del INTA. Es desde aquí donde puede comenzar una política pública desde un diálogo comprometido.

$\checkmark$ Promover el fortalecimiento de las organizaciones, acompañando los procesos comunitarios, a la vez que brindar y construir conjuntamente herramientas y dinámicas para solventar problemas, encarar proyectos, organizar el trabajo cotidiano.

$\checkmark$ Fomentar y proyectar la visibilización de los actores colectivos del territorio. En esto de fortalecer las organizaciones sociales, una de las maneras de emprender el trabajo es en tanto lograr una mayor visibilización, presencia, y peso socio-cultural de las prácticas comunitarias. El objetivo es que las organizaciones comiencen a disputar la agenda política local de sus ciudades, pueblos, parajes. 
$\checkmark$ Facilitar la conformación de lazos y encuentros entre las organizaciones, para potenciar su llegada territorial, promoviendo las fortalezas de trabajar en red.

$\checkmark$ En cuanto a visibilización, otra estrategia a encarar con más fuerza es la radio comunitaria. En el $80 \%$ de las organizaciones visitadas mostraron un sostenido interés por lograr un espacio en la radio, o en el caso de algunas (MOCAFOR) levantar una radio comunitaria desde cero. La estrategia será compartir con las organizaciones la nueva ley de Servicios Audiovisuales, conocerla en profundidad, discutirla. Armar talleres sobre la cuestión de la radio popular, que tenga el eje tecnológico, y el eje contenidos. Otra posibilidad a sumar es lograr encuentros con organizaciones que ya tienen instalada y en funcionamiento una radio comunitaria. 


\section{Bibliografía (por orden alfabático)}

Alemany, Carlos "Volvió la extensión y se armó la discusión" en Cimadevilla, Thornton Grises de la Extensión, la Comunicación y el Desarrollo. Ediciones INTA 2008.

Álvarez Leguizamón, Sonia. "El Discurso de la Participación en las políticas sociales de "lucha contra la pobreza", contradicciones y ambivalencias." Sonia Álvarez Edición Consejo de Investigación de la Universidad Nacional de Salta. Argentina. 2008.

Amin, Samir "Capitalismo, imperialismo, mundialización", en Seoane, Taddei, Resistencias mundiales. De Seattle a Porto Alegre (Buenos Aires: CLACSO)

Anderson, Perry "Neoliberalismo: un balance provisorio", en Sader, Emir, gentili La trama del neoliberalismo. Mercado, crisis y exclusión social (Buenos Aires: Oficina de publicaciones del CBC-UBA) $1^{\text {a }}$ edición. Pág. 15-27. 1997

Araya, José Maria Julio. La revolución Científico-Tecnológica. Claves para su comprensión y formas porsibles de afrontar sus efectos. En Ecos de Grado y Posgrado

Argumedo, Alcira. Crisis de las Ciencias Sociales de la Argentina en Crisis. Prometeo Libros. Buenos Aires 2005.

Baccin, Cristina, La Comunicación Institucional, UNICEN 2011

Barrientos, Mario "La participación. Algunas precisiones conceptuales". En La Extensión Rural, Facultad de Ciencias Agrarias. Universidad de Córdoba. 2005.

Beltrán, Luis Ramiro, Comunicattion research in Latin America: ¿the blind folded inquiry?, International Scientific Conference on Mass Comunicattion and Social Consciousness in a Changing World, IAMCR, Leipzig,. 1974. 
Bisang, Roberto. Libremercado, intervenciones estatales e instituciones de ciencia y técnica en la Argentina: apuntes para una discusión. Redes, Vol. 2, Núm. 3, abril, 1995, pp. 1358 Universidad Nacional de Quilmes

Bonanno, Osvaldo. “Castoriadis”, en Revista El Emergente Psicosocial Nº1, 2008.

Boron, Atilio. "La sociedad civil después del diluvio neoliberal", en La trama del neoliberalismo. Mercado Crisis y exclusión social, Sader y Gentilli. Clacso-Eudeba. Buenos Aires 1999.

Bosco Pinto, Joao: "Extensión o educación”: una disyuntiva crítica, Instituto Interamericano de Ciencias Agrícolas Zona de las Antillas: Santo Domingo, 1977 Educación Liberadora, dimensión teórica y metodológica. Ediciones Búsqueda. Buenos Aires. 1976.

Brandes, E; Bontempo, M; Cazón, C; Chapay, M; Corneo, J.G; Matusevich, M; Puig, A; Ciencia, C; Barreto, M.L.; Vecchi, J.L. Documento de Comunicación Institucional. Ediciones INTA. Buenos Aires 1997.

Bunge, M. Filosofía política. Barcelona, Gedisa 2008.

Cardoso, Nelson. La Comunicación Comunitaria. Bibliografía Modulo 1. Taller Cuatrimestral de Comunicación Comunitaria. 2000.

Castells, Manuel. La Era de la Información. Vol. II: El poder de la identidad. México, Distrito Federal: Siglo XXI Editores. 2001.

Castoriadis, Cornelius. "La institución imaginaria de la sociedad". Tusquets Editores, México 1975

Chiarulli, Simón, Machado, Soto, Vigil, "Cambiando de rumbo. Reflexiones sobre desarrollo sustentable de las familias de pequeños productores rurales argentinos". INCUPO FUNDAPAZ Be.Pe. Red Agroforestal Chaco Argentina SUR. 2005 
Chomski, Noam; Ramonet, Ignacio. Como nos venden la moto. Información, poder y concentración de medios. Barcelona: Icaria. 1995.

Cimadevilla, Carniglia, Cantú. La bocina que parla, Antecedentes y Perspectivas de los Estudios de Comunicación Rural. Ed. Universidad Nacional de Río Cuarto.

Díaz Bordenave, Juan. El método del arco, una forma de hacer educación problematizadora. Edición Decisio Educación Popular. México. 2005

Dominguez, Lapegna y Sabatino, "Agriculturas en tensión en Colonia Loma Senés" en Giarracca, Teubal "El campo argentino en la encrucijada. Estrategias y resistencias sociales, ecos en la ciudad”. Alianza Editorial. Buenos Aires. 2005.

Escobar, Arturo. La invención del Tercer Mundo construcción y deconstruccion del desarrollo. Editorial Norma.México. 1996.

Freire, Paulo. ¿Extensión o Comunicación? La concientización del medio rural.Siglo XXI Editores. México. 1973.

Freire, Paulo. "Hacia una pedagogía de la pregunta. Conversaciones con Antonio Faúndez". Ediciones La Aurora. Suiza. 1985.

Fuentes Navarro, Raúl. La investigación de la comunicación en Ámerica Latina: condiciones y perspectivas para el siglo XXI. Díalogos de la Comunicación N 56, Felafacs, Lima, 1999.

García Delgado, Daniel. Estado y Sociedad. Tesis Norma. Buenos Aires 1994.

Gárgano, Cecilia La reorganización de las agendas de investigación y extensión del Instituto Nacional de Tecnología Agropecuaria (INTA) durante la última dictadura militar (19761983). Ponencia. En Esocite 2010 Jornadas Latinoamericanas de Estudios Sociales de la 
Ciencia y la Tecnología. Buenos Aires. 2010.

Geilfus, F., 1997. 80 herramientas para el desarrollo participativo: diagnóstico planificación, monitoreo, evaluación. IICA-GTZ, San Salvador, El Salvador.

Gutiérrez, Thais. La construcción transnacional de la idea de políticas de alivio a la pobreza y de sus aplicaciones. En Daniel Mato (coord.), Políticas de economía, ambiente y sociedad en tiempos de globalización. Caracas: Facultad de Ciencias Económicas y Sociales, Universidad Central de Venezuela, pp. 191-209. (2005)

Häns-Júrgen Burchart Desigualdad y Democracia Revista NUEVA SOCIEDAD No 215, mayo-junio de 2008, pág 80.

Harvey, David El nuevo imperialismo AKAL. Madrid. 2004

Huergo, Jorge Desafíos a la extensión desde la perspectiva cultural. Revista Dialoguemos. Ediciones INTA. 2004

INTA Documentos Historia del INTA. Ediciones INTA. 2006.

INTA Documentos. Institucional. Comunicación. Página web www.inta.gov.ar (1995-2006) Ediciones INTA.

INTA Documentos, Programa Minifundio. Ediciones INTA. 2007.

INTA Documentos. Gerencia de Comunicaciones. En Institucional. Ediciones INTA página web. 2011.

INTA Documentos. Delgado, Gabriel. Informe Plan Mediano Plazo. Documento Interno. INTA. 2009 
INTA Documentos. Muani, J. y Bonetto, L. A. (1994). La participación como método. Programa Cambio Rural. Gerencia de Extensión. INTA. [On line]. (consulta 10-10-2007).

INDEC Instituto Nacional de Estadísticas y Censos. Censo y estadística 2010. Censo Agropecuario.

Kaplan Mario, La Planificación Latinoamericana: Concepciones y experiencias. Boletín Mexicano de Derecho Comparado, vol. XXIV, num. sep - dic. 1991.

Lampolla, Alberto en Verbitsky El Predador, Página 12. 2009.

León, Rosario. Reflexiones sobre el concepto de participación.. En "Bosques, Árboles y Comunidades Rurales". Revista Nº 25. Cochabamba, Bolivia. 2008.

Lerner, Daniel and Schramm, Wilbur, Eds. Communication and change in the developing countries. Honolulu, Hawaii, East-West Center Press, University of Hawaii. 1967. Lerner, Daniel . The passing of traditional society. Glencoe, Illinois, Free Press.1958

Maguerez, Charles. Análise do sistema paulista de assistencia a agricultura. Campinas, Relatorio de Assistencia prestada à Cordenadoria de Assitencia Técnica Integral (CATI), 1970.

Makler, Carlos. Las corporaciones agropecuarias ante la política agraria peronista (19731974) Graciano, Gutiérrez en El agro en cuestión. Discursos, Políticas y Corporaciones en la Argentina, 1870-20. Prometeo Libros. Buenos Aires.2006

Martín-Barbero, Jesús Martín; De los medios a las mediaciones, de. G. Gilli, Barcelona, 1987.

Mattelart, Armand y Michele. Historia de las teorías de la comunicación. Ed. Paidós. 1997.

Mattelart, Armand - Multigner ,Gilles. La comunicación-mundo: historia de las ideas y de las 
estrategias. Siglo XXI Editores.

Prebisch, Raúl. Informe de la Comision Económica para América Latina. (1959)

Preston, P.W. Una introducción a la teoría del desarrollo. Ed. Siglo XXI. 1999.

Prieto Castillo, Daniel; Diagnóstico de la comunicación, CIESPAL, Quito, 1990, pág. 54

Prieto Castillo, Daniel Una introducción a la comunicación rural. Ediciones INTA. Buenos Aires. 1994.

Ramonet, Ignacio. La pensée unique. Editorial. Le Monde Diplomatique, 1995

Red Agroforestal Chaco Argentina (REDAF). Informe Ejecutivo "Conflictos de Tierra y Medioambiente en la región del Chaco-Argentino". 2009.

Resolución Nº182-07 de la Universidad Nacional de Lomas de Zamora. Publicada en Los secretos de la universidad pública. Períodico MU. Cooperativa La Vaca. Buenos Aires. Marzo 2009

Rincón García, Luis Antonio. Un acercamiento a los procesos comunicacionales en la comunidad indígena tzotzil de Zinacantán, en Zona Altos de Chiapas, México. Tesis de Maestría. Facultad de Periodismo y Comunicación Social. Maestría en Planificación y Gestión de Procesos Comunicacionales. 2005.

Robirosa Mario; Caldarelli Graciela; Lapalma Antonio. Caleti, Sergio. Turbulencia y Planificación Social. UNICEF. Siglo XXI Ediciones. Buenos Aires (1996).

Rogers, Everett en García Urrea, Difusión de Innovaciones, Material Didáctico. Edit. Scribd.com . Enero 2008.

Rogers, Everett La comunicación de Innovaciones. (Trad. Ricardo Vinos) México. 1974. Pág 
347.

Rose, Nikolas . "El gobierno en las democracias liberales "avanzadas": del liberalismo al neoliberalismo". En Archipiélago: Cuadernos Crítica De La Cultura. (1997).

Rostow, Walter Whitman. Las etapas del crecimiento económico. Editorial Fondo de Cultura Económica. 1961

Salazar Villalba, Claudia M. El sujeto no es objeto de investigación. Trabajo presentado en el cuarto encuentro de investigadores en Psicología del Mercosur, 2008.

Santamaría, Karlos (s/f): "El concepto de fetiche", en El Diario Vasco.

Sanz, Patricio, Cavallero, María Inés, "Imágenes de una Actividad Solidaria. Elaboración de remedios caseros para la comunidad" Grupo Semilla de Vida, 2003.

Schaller, Alberto. "Aniversario de la Estación Experimental "El Colorado " del INTA". Ediciones INTA. El Colorado, Formosa, 2007.

Schramm, Wilbur . Communication development and the development process. In: Pye, Lucien W., ed. 1963.

Communications and political development. Princeton, N.J., Princeton University Press.

Sousa Santos, Boaventura; "Renovar la teoría crítica y reinventar la emancipación social." Encuentro en Buenos Aires. CLACSO. Buenos Aires, 2006.

Sousa Santos, Boaventura 2003. Crítica a la razón indolente. Contra el desperdicio de la experiencia (Bilbao: Desclee de Brouwer).

Thomas Llaguno, Esteban "Prolegómenos de colonialidad en América Latina. La planificación y la Alianza para el Progreso (1961-1965)” Ed. Rebelión.org 2010. 
Tompson, John (1991) "La comunicación masiva y la cultura moderna. Contribución a una teoría crítica de la ideología”, en Revista Versión, Nº̂, universidad Autónoma Metropolitana, México. 1991.

Torres, C y Nocetti, J (1994) en Alemany, carlos. Apuntes para la contrucción de los preíodos históricos de la Extensión Rural del INTA. En Thornton, Cimadevilla. La Extensión Rural en Debate. Ediciones INTA. Buenos Aires 2003.

Unidad de Prácticas y Producción de Conocimiento. Sembrando mi tierra de futuro. Ediciones de Periodismo y Comunicación. 2011.

Van Dijk, Teun A “Análisis del Discurso Ideológico” Versión 6 UAM México. 1996. pp. 15-43.

Vinuesa, Juan Diagnóstico Integral Oeste Formoseño. Ediciones INTA. 2007.

Zemelman, Hugo, Pensar teórico y pensar epistémico: los retos de las ciencias sociales latinoamericanas, Instituto Pensamiento y Cultura en América Latina, México. 2008. 